Geology of the

Attean Quadrangle,

Somerset County,

Maine

\begin{tabular}{ll|lll} 
GEOLOGICAL SURVEY BULLETIN 1297
\end{tabular}

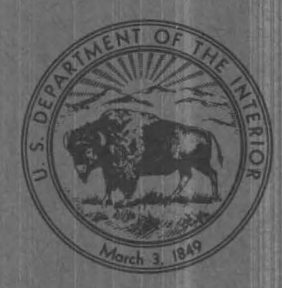





\section{Geology of the}

\section{Attean Quadrangle,}

\section{Somerset County,}

\section{Maine}

By ARDEN L. ALBEE and EUGENE L. BOUDETTE

With a section on GEOLOGIC INTERPRETATION OF THE AEROMAGNETIC MAP

By JOHN W. ALLINGHAM and ARDEN L. ALBEE

G E L O I A L S U R E Y B U L L E I N 1297

Description of the geology of a glaciated terrane of lower Paleozoic rocks along the crest of the Boundary Mountain anticlinorium

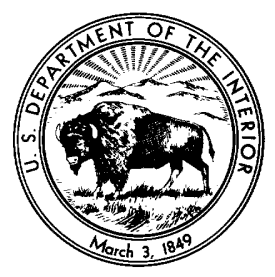




\section{UNITED STATES DEPARTMENT OF THE INTERIOR}

ROGERS C. B. MORTON, Secretary

\section{GEOLOGICAL SURVEY}

W. A. Radlinski, Acting Director

Library of Congress catalog-card No. 77-181825

For sale by the Superintendent of Documents, U.S. Government Printing Office Washington, D.C. 20402 


\section{CONTENTS}

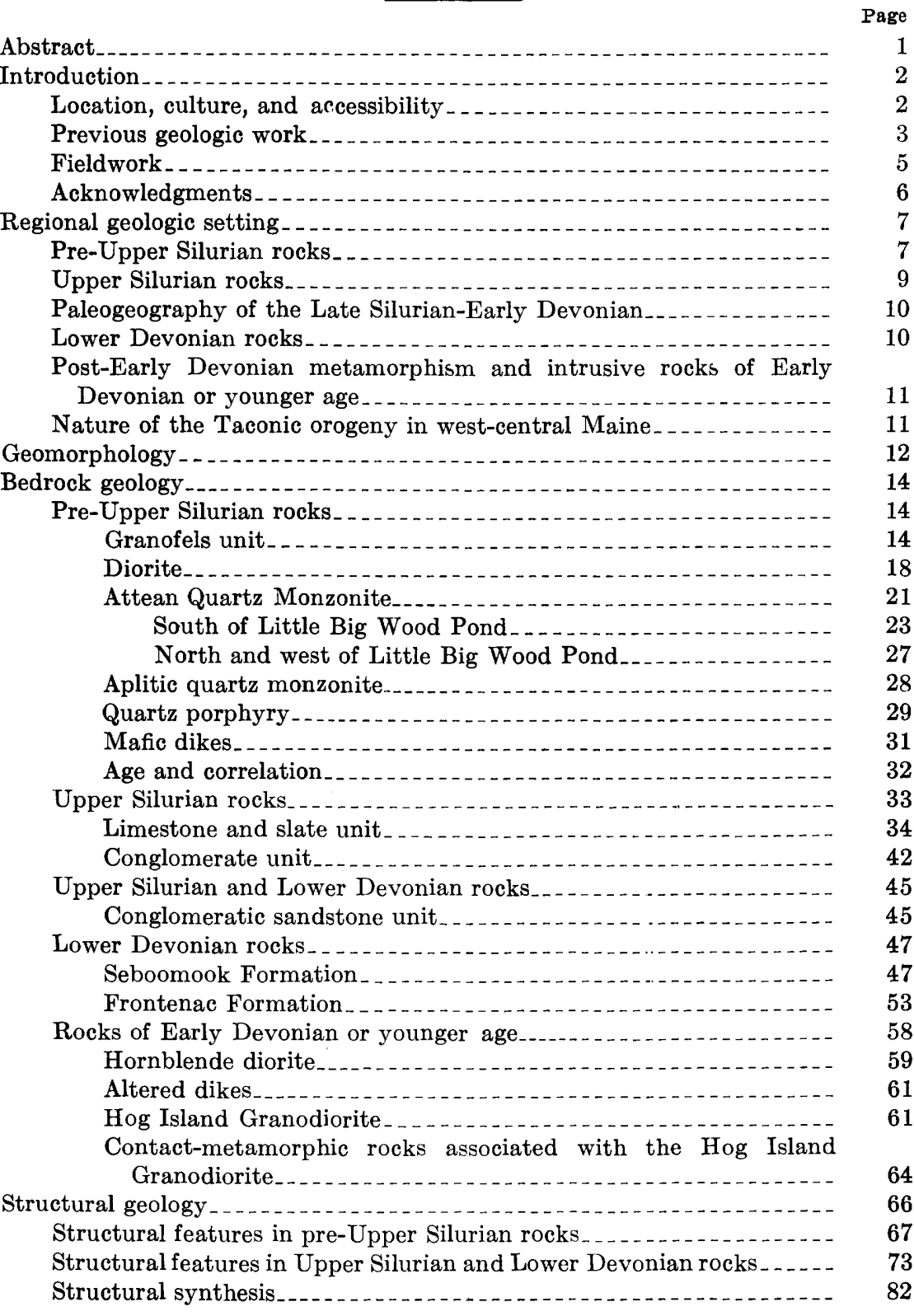




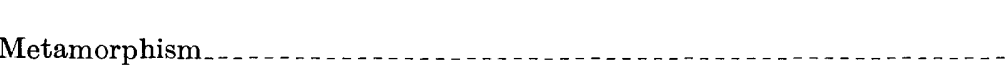

Page

Pre-Upper Silurian rocks . . . . . .

Upper Silurian and Devonian rocks............ 85

Radiometric age determinations . .

Quaternary geology

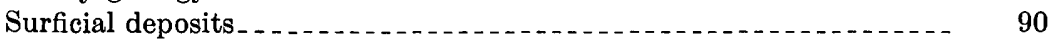

Preglacial topography and erosion by ice

Direction of ice flow . ... 96

Geologic interpretation of the aeromagnetic map, by John W. Allingham and Arden L. Albee

References cited. 102

Index

\section{L L US T R A T I O N}

[Plates 1-4 in pocket]

Plate 1. Bedrock geologic map and sections and magnetic profiles of the Attean quadrangle, Somerset County, Maine.

2. Bedrock geologic maps and section of the Foxs CampWood Stream area, Attean quadrangle.

3. Geologic sketch map of a roadcut section in the Frontenac Formation along east side of U.S. Route 201 in the Sandy Bay quadrangle near the northern margin of the Attean quadrangle.

4. Surficial geologic map of the Attean quadrangle.

Figure 1. Index map showing location of and access to the Attean

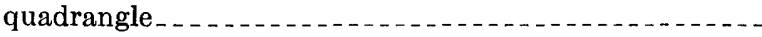

Page

2. Generalized geologic map of west-central Maine, northern New Hampshire, and adjacent Quebec.............

3. Photomicrographs showing alteration and cataclasis in the Attean Quartz Monzonite.....................

4. Aerial photograph showing topographic expression of joints in the Attean Quartz Monzonite.............................

5. Point diagrams of joints from 16 areas within the Attean quadrangle, and map showing location of these areas and topographic linear features plotted from aerial

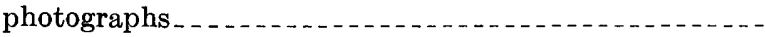

6. Photomicrographs of transverse cleavage showing direct correlation of spacing of cleavage planes with grain size and percentage of granular minerals...............

7. Photomicrographs showing widely spaced transverse

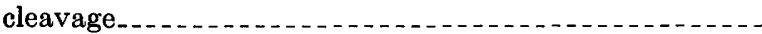

8-10. Photographs:

8. Refracted cleavage in graded beds in the Seboomook Formation

9. Fossils (brachiopods) flattened in the plane of cleavage from calcareous slate near Foxs Camp.

10. Small folds in the Frontenac Formation......... 
Figdre 11. Photomicrographs showing relations between transverse cleavage and bedding in small folds in the Seboomook Formation.

12. Aerial photograph showing the vegetation contrast and surface appearance of bouldery till and swamp deposits ....

\section{T A B L E S}

TABLE 1. Estimated modes of the granofels unit, Attean quadrangle, Maine

Page

2. Estimated modes of diorite $\ldots$

3. Modes and dominant grain sizes of the Attean Quartz Monzonite

4. Chemical analysis and CIPW norm of the Attean Quartz Monzonite

5. Estimated modes and dominant grain sizes of quartz porphyry dikes.

6. Estimated modes and medial grain sizes of calcareous rocks of the limestone and slate unit.

7. Estimated modes and grain sizes of the conglomeratic sandstone unit and Seboomook Formation.

8. Chemical analyses, calculated modes, and relative proportions of cations in chlorite of slate from the Seboomook Formation and slate and sandstone from related formations from west-central Maine and New Hampshire....

9. Estimated modes and grain sizes and some properties of chlorite from samples of the Frontenac Formation, Attean and Sandy Bay quadrangles, Maine..........

10. Measured modes of $\mathrm{Hog}$ Island Granodiorite, Attean quadrangle, Maine

11. Chemical analysis, CIPW norm, and calculated mode of typical Hog Island Granodiorite, Attean quadrangle, Maine

12. Potassium-argon and rubidium-strontium age determinations from the Attean and Long Pond quadrangles, Maine

13. Lead-alpha age determinations on zircon from the Attean Quartz Monzonite and Hog Island Granodiorite in the Attean and Long Pond quadrangles, Maine............

14. Magnetic susceptibilities and densities of rock units in the Attean quadrangle, Maine....................... 



\title{
GEOLOGY OF THE ATTEAN QUADRANGLE, SOMERSET COUNTY, MAINE
}

\author{
By Arden L. Albee and Eugene L. Boudette
}

\begin{abstract}
ABSTRAGT
The Attean quadrangle is on the crest of a major structural feature, the Boundary Mountain anticlinorium, which extends from northern New Hampshire northeast into Maine. The geologic units include (1) pre-Upper Silurian rocks, (2) Upper Silurian and Lower Devonian metasedimentary rocks, (3) intrusive rocks of Early Devonian or younger age, and (4) unconsolidated Quaternary deposits. Fossils have been found only in the Silurian and Devonian rocks, and the ages of the other rocks are determined by their relations to the fossiliferous units.

The pre-Upper Silurian rocks consist of a complex of quartzofeldspathic metasedimentary rocks-the granofels unit-that are intruded successively by diorite, the Attean Quartz Monzonite, quartz porphyry dikes, and mafic dikes.

Upper Silurian and Devonian rocks include a limestone and slate unit, which consists mainly of calcareous metapelite grading into and interbedded with limestone; a conglomerate unit, which is predominantly a boulder conglomerate; and a conglomeratic sandstone unit, which consists of calcareous quartz-feldspar sandstone and granule conglomerate. The first two units contain Late Silurian fossils, occur in discontinuous lenses between the Seboomook Formation and the pre-Upper Silurian rocks, and rest unconformably upon the latter. The conglomeratic sandstone unit intertongues with the limestone and slate unit and with the Seboomook Formation, so that it must include Silurian and Devonian rocks.

The Seboomook Formation consists predominantly of gray slate and contains Early Devonian fossils; it appears to grade stratigraphically upward into the Frontenac Formation, which is characterized by thick argillaceous sandstone. The Frontenac has not been dated paleontologically, and its age is arbitrary; it is tentatively correlated as a sandy facies of the Seboomook Formation.
\end{abstract}

Rocks of Early Devonian or younger age include sills and dikes of hornblende diorite, the Hog Island Granodiorite, and two small dikes altered to dolomite. The hornblende diorite seems to have been affected by the regional metamorphism in Middle Devonian time, but the Hog Island Granodiorite is younger.

At least 90 percent of the Attean quadrangle is covered by unconsolidated till, outwash sand and gravel, ice-channel fillings, alluvium, and swamp deposits of glacial or fluvial origin. 
Potassium-argon, strontium-rubidium, and lead-alpha age determinations of representative metamorphic or igneous minerals and rocks indicate that the regional metamorphism and the intrusion of the Hog Island Granodiorite occurred nearly simultaneously about 360 million years ago but that the intrusion was slightly after the peak of the regional metamorphism. Comparison with isotopic ages measured elsewhere, on samples from rocks which have good stratigraphic control, indicates that the metamorphism is most likely of Middle Devonian age.

A striking general correlation exists between the total magnetic intensity shown on the aeromagnetic map and the distribution of units shown on the bedrock geology map. Moreover, the individual magnetic anomalies correlate with the detailed bedrock geology.

Pre-Upper Silurian rocks contain relicts of high-grade metamorphic minerals and have a regional trend which apparently diverges from that of the Upper Silurian and Devonian formations (determined in part by reconnaissance mapping in west-central Maine). This relation suggests that the Taconic orogeny (Ordovician) resulted in major deformation in this area and was followed by erosion prior to deposition of Upper Silurian sediments. For these reasons, the pre-Upper Silurian units are assigned an Ordovician or older age.

\section{INTRODUCTION}

\section{LOCATION, GULTURE, AND ACCESSIBILITY}

The Attean 15-minute quadrangle is bounded by parallels $45^{\circ} 45^{\prime}$ and $45^{\circ} 30^{\prime} \mathrm{N}$. and by meridians $70^{\circ} 15^{\prime}$ and $70^{\circ} 30^{\prime} \mathrm{W}$. It includes approximately 197 square miles of Somerset County, west-central Maine, and about 12 square miles of the electoral district of Frontenac, Province of Quebec, Canada. The Canadian part of the quadrangle is not described in this report; it has been described by Marleau (1958a, 1958b).

Jackman and adjacent Moose River are the only villages in the area. The population of Jackman in 1960 was about 1,000; that of Moose River, about 200. Some railroad employees and U.S. Customs and U.S. Immigration officers formerly lived in Holeb on the west side of the quadrangle, but this hamlet was closed by the Canadian Pacific Railroad in July 1958. Many Canadian Pacific Railroad employees and U.S. Immigration, Customs, and Border Patrol employees do, however, live in the area. Most of the dwellings that are shown on the topographic map away from the main roads no longer exist, but private camps are present on a number of lakes and streams. Commercial recreation camps were being operated in 1960 on Birch Island in Attean Pond, on Birch Island in Holeb Pond, at Turner Pond, and at Crocker Pond.

The economy of the area is based primarily upon the forest; lumbering, paper-pulp logging, and the provision of hunting, fishing, and tourist accommodations are major occupations. Virtually no agricul- 
ture is practiced, although a small amount of hay is cut for cattle feed.

The Attean quadrangle is heavily forested except for small areas along the main road. Accessibility is largely dependent upon the course of logging operations; logging roads and trails provide access to the area, but heavy undergrowth rapidly springs up following logging and makes foot travel difficult. The virgin pine was cut prior to the memory of the local inhabitants; virgin spruce was cut before, during, and for some time after World War I; and virgin hardwood, mainly yellow birch and maple, was being cut in the western part of the quadrangle during the course of the fieldwork. Softwood for paper pulp has been cut recurrently in the eastern part of the area but has not been cut since the 1920's in the western part, except in Town 6R7, where cutting was begun during the course of the fieldwork.

Many of the roads and trails shown on the topographic map are no longer usable and others have been built. The part of U.S. Route 201 that traverses the northeastern part of the area has been relocated and improved. Figure 1 shows the locations of the paved and graveled roads, as of the close of fieldwork in 1959. Major trails or bulldozed logging roads which will probably be walkable for many years are also shown. No attempt is made to show blazed trails or the smaller logging trails, although they do provide access to many parts of the area.

Lakes and ponds in the area provide a convenient means of access by the use of small watercraft. The entire length of Moose River within the quadrangle is navigable by canoe, dependent upon water level and willingness to portage. There are good portage trails around Holeb Falls and Attean Falls (in the Long Pond quadrangle) on the Moose River, and between Holeb and Attean Ponds. The map, however, shows the channels incorrectly at Holeb Falls, and it is wise to obtain services or instructions from local guides. Float planes flown by experienced pilots may be landed on many of the ponds in the quadrangle, including those as small as Little Turner Pond.

\section{PREVIOUS GEOLOGIC WORK}

Previous geologic work in west-central Maine was focused on the rocks of the Moose River synclinorium, east of the Attean quadrangle. The Devonian rocks of the Moose River synclinorium were first recognized by Jackson (1837) near Parlin Pond, about 11 miles southeast of Jackman. Holmes and Hitcheock $(1861,1862)$ and Hitchcock and Huntington (1874) presented the earliest geologic maps of the region. Invertebrate fossils from the Moose River synclinorium were described by Clarke (1907, 1909) and by Williams and Breger (1916). Keith (1933) prepared a geologic map of Maine, but the west-cental part is 


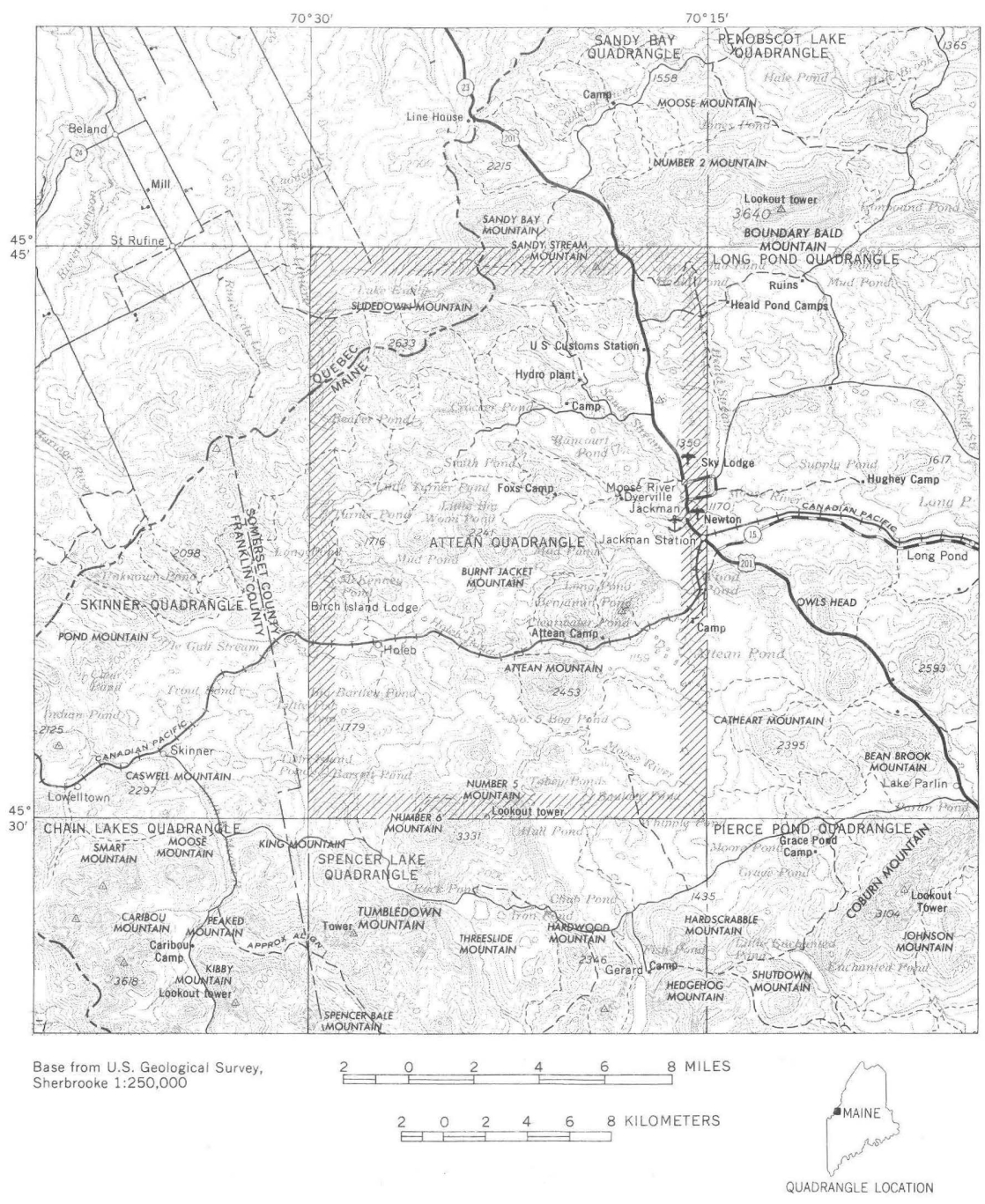

Frgure 1.-Location of Attean quadrangle and access to the quadrangle and adjacent areas in 1959 .

inaccurate. Hurley and Thompson (1950) made a geologic reconnaissance to accompany an airborne magnetometer survey. Their map $(1: 125,000)$ indicates the limit of the Moose River synclinorium. They recognized the unconformity above the pre-Upper Silurian rocks and collected fossils in the vicinity of Foxs Camp. Their aeromagnetic map clearly outlines the Hog Island Granodiorite stock, although they did not recognize it. Boucot (1961) summarized a 1948-54 study of the rocks and invertebrate fossils of the Moose River synclinorium. $\mathrm{He}$ 
made fossil collections from the Foxs Camp area and discovered a diagnostic Early Devonian fossil in the Seboomook Formation at Moose River village. Some results of the present investigation have been included in Boucot's report and on his map. Recent mapping and aeromagnetic studies by the U.S. Geological Survey and others in northern Maine have been compiled at scale of 1:250,000 (Boucot and others, 1960).

The Quebec part of the Attean quadrangle, and adjacent Canadian areas to the north and south along the international boundary, have been described by Marleau (1957, 1958a, 1958b, 1959). Albee (1961) described the tectonic setting of the region. Perkins (1934, p. 144-145) discussed the distribution of glacial outwash in the Attean area and indicated its distribution on his map of glacial deposits in Maine.

\section{FIELDWORK}

Approximately 20 man-months were spent in the field between July 1956 and October 1958; several weeks were spent field checking in 1959 and 1961. Geology was compiled at a scale of $1: 48,000$. The 1925 edition of the Attean 15-minute quadrangle, U.S. Geological Survey, was used as a base. Most of the geologic field observations were made at stations located by combination pace-and-compass and altimeter traverse. Other stations, accurately located on aerial photographs by inspection, were transferred to the base map by the use of radial-line intersections. In most areas the locations of geologic contacts were plotted correctly with respect to the rather generalized topography shown on the base map, but on Sandy Stream Mountain and Slidedown Mountain and in the Foxs Camp-Wood Stream area the contacts and structure symbols were plotted relative to accurate planimetry from photogrammetric work. The Foxs Camp-Wood Stream area, which contains most of the fossil localities, is shown in greater detail on another base map.

Aerial photographs (1942), at a scale of about 1:21,000, were used during the course of fieldwork. After the close of the 1958 field season, aerial photographs (1958), at a scale of about 1: 55,000, became available. These 1958 photographs, because of their smaller scale, could be oriented and scaled by radial-line intersections to points on the base map which along believed to be planimetrically correct. The points chosen were along the international boundary, U.S. Route 201, and the Canadian Pacific Railroad. Radial-line intersections were then used to locate additional control points with which to orient and scale the older more detailed photographs. A reflecting projector was used to transfer information from both sets of photographs to the base map. The linear features shown on the bedrock geologic map and 
many contacts on the surfical geology map were similarly transferred.

Locations, including those of specimens cited in the tables, are given by a convenient reference system. The quadrangle map is divided into nine 5-minute sections, which are designated northeast, east-central, southeast, south-central, and so forth, abbreviated NE, EC, SE, SC, and so forth. Within each ninth the southwest corner is the origin, and decimal rectangular coordinates are used to fix any point; the first figures designate miles east, and the last figures designate miles north of the origin. Thus, NW-1.05, 2.03 indicates a point 1.05 miles east and 2.03 miles north of the southwest corner of the northwest ninth of the quadrangle. Unless prefixed by a quadrangle name, all such locations are in the Attean quadrangle.

\section{ACKNOWLEDGMENTS}

The authors were assisted in the field in 1956 by David Wilkinson and William Albee, in 1957 by William Neuguth, and in 1959 by Kerry Pinette and Gordon Newton. The assistance of Wilkinson and Neuguth was provided by the Maine Geological Survey through John P. Rand, State Geologist. The support of the Division of Geological Sciences, California Institute of Technology, where Albee carried out so much of the laboratory study and report preparation, is gratefully acknowledged.

Professor Arthur J. Boucot, while at the Massachusetts Institute of Technology, contributed his time and knowledge to provide us with fossil identifications. R. B. Neuman, E. L. Yochelson, A. R. Palmer, and J. M. Berdan-all of the U.S. Geological Survey-also provided fossil identifications.

Throughout the course of the fieldwork, we were helped frequently by the people of Jackman, Moose River, and Holeb, and we maintained a most cordial relationship with them. Pulp and lumber operators and their employees, members of the Maine Forest Service, members of the Maine Warden Service, and local guides frequently contributed their time and assistance during the conduct of the work. Their advice on access routes and shelters was especially helpful. Ernest Guay of Jackman, by allowing us to use his camps and canoes at Turner Pond, expedited the work in that area.

Field conferences and discussions with many geologists interested in or working in northern New England and adjacent Canada were stimulating and informative. Raymond A. Marleau, of the Quebec Department of Mines, mapped concurrently in the Quebec area immediately adjacent to the Attean quadrangle, and the liaison we maintained with him was particularly helpful. 


\section{REGIONAL GEOLOGIC SETTING}

During the course of our work in the Attean quadrangle, geologic mapping in west-central Maine, northern New Hampshire, and adjacent Quebec has greatly clarified the stratigraphic and structural picture of the region, although it is still not well understood. This summary and the simplified regional geologic map (fig. 2) are based in part on a compilation by Boucot, Griscom, Allingham, and Dempsey (1960), on a regional study in Quebec by Marleau (1958b), and on our work, both in the Attean quadrangle and in the area of reconnaissance mapping to the southeast.

The Attean quadrangle is on the crest of the Boundary Mountain anticlinorium (Cady, 1960, p. 536; Albee, 1961), a major feature extending from northern New Hampshire northeast into Maine. It is outlined, as shown in figure 2, by a major regional unconformity between rocks of probable Cambrian or Ordovician age in its core and units of Late Silurian and Early Devonian age on its margins. In Maine, the northward-plunging anticlinorium is bifurcated at its northern end by the Moose River synclinorium, which contains a great thickness of well-dated rocks of Early Devonian age. Northwest of and parallel to the Boundary Mountain anticlinorium, a sandy facies of the Devonian, the Frontenac Formation, outlines the core of the Frontenac synclinorium, which is part of the major Connecticut Valley-Gaspé synclinorium (Cady, 1960, p. 536). The Frontenac synclinorium is inferred from stratigraphic superposition datapillow structures in volcanic rocks - on either limb of the fold (Marleau, 1958b, p. 85-86, 89). Northwest of the Frontenac synclinorium, Cambrian and Ordovician rocks crop out in the core of the Green Mountain-Sutton Mountain anticlinorium; the stratigraphic and geotectonic relationships of these rocks have been described by Cady (1960).

\section{PRE-UPPER SILURIAN ROGKS}

The pre-Upper Silurian rocks in the area are overlain unconformably by units ranging in age from Middle Silurian (Wenlock) to Early Devonian (Becraft-Oriskany). Reconnaissance mapping suggests that at least three major units can be distinguished in the preUpper Silurian rocks (the metamorphic and volcanic rocks in fig. 2). The two slate and phyllite units shown in figure 2, east of the Moose River synclinorium, include a felsic volcanic unit, the Kennebec Formation, which contains Middle Ordovician fossils (Boucot, 1961, p. 183). The easternmost of these two units, the green phyllite and the red and green slate, seems to be continuous with rocks mapped as Albee Formation (Ordovician) by Green (oral and written communs., 196061 ) in the Errol quadrangle in northern New Hampshire. The north- 


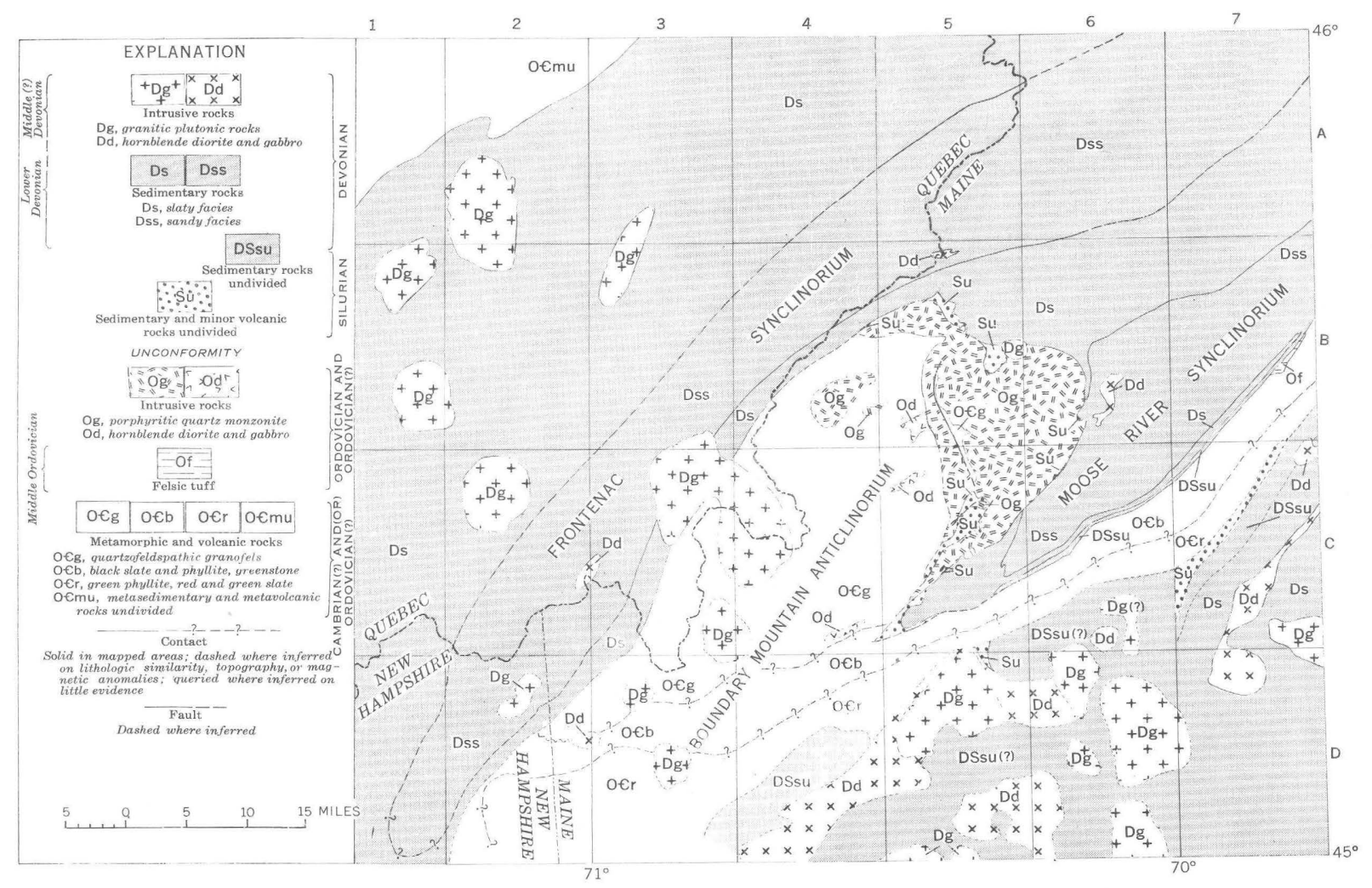

Figure 2.-Generalized geologic map of west-central Maine, northern New Hampshire, and adjacent Quebec. Attean quadrangle is B-5. Modified from Albee (1961, p. C52). 
ern part of the Boundary Mountain anticlinorium is underlain by a quartzofeldspathic granofels unit which contains abundant lithic fragments. This rock unit extends as far south as the southern edge of the Chain Lakes quadrangle (fig. 2, C-4) and along the international boundary on the east side of the Arnold Pond quadrangle (C-3). On the west side of the Cupsuptic quadrangle (D-3) and the east side of the Second Lake quadrangle (D-2), a pebbly feldspathic graywacke is found north of the two slate and phyllite units. The relationships of the granofels and graywacke have not yet been demonstrated because of poor accessibility in the intervening area; however, the graywacke is probably a lithologic equivalent of the granofels, and it is included with the granofels on the map.

Although the granofels unit was assigned to the Precambrian by Boucot (1961, p. 185), more likely it should be tentatively assigned an Ordovician or Cambrian age. Allowing for reasonable sedimentary and metamorphic differences, the granofels is similar to rocks in the vicinity of Dixville Notch in northern New Hampshire. The Dixville Notch rocks are assigned to the Ordovician (Hatch, 1963, p. 18) and seem to intertongue along the Maine--New Hampshire border with the feldspathic graywacke. More detailed mapping by John Green (oral commun., $1960 ; 1962)$ in the Second Lake quadrangle (D-2) also seems to support this interpretation.

The pre-Upper Silurian metasedimentary rocks are intruded by diorite or gabbro, which in turn is intruded by the coarse-grained porphyritic Attean Quartz Monzonite. These intrusive rocks are also overlain unconformably by the Upper Silurian rocks. Similarity of lithologic characteristics and of stratigraphic relationships suggests that the quartz monzonite is equivalent to the Highlanderoft Plutonic Series of New Hampshire (Billings, 1956, p. 46-48, 106). Many small ultramafic bodies also intrude the pre-Upper Silurian rocks. Ultramafic intrusive rocks throughout New England are almost entirely confined to Cambrian and Ordovician rocks and have commonly been assigned an Ordovician age. Several serpentinite masses, however, intrude the Frontenac Formation. (Lower Devonian) in the Woburn quadrangle (fig. 2, C-3) (Marleau, 1958b, p. 120).

\section{UPPER SILURIAN ROCKS}

Silurian rocks occur as discontinuous lenticular units and include limestone, calcareous sandstone and mudstone, conglomerate, arkose, limestone conglomerate, and felsic volcanic rocks. Many units are dated by paleontologic evidence as Late Silurian (early Ludlow) and one as Middle Silurian (Wenlock), but several can be dated only as pre-Early Devonian (Becraft-Oriskany). No rocks of late Ludlow Age are known. In the Spencer Lake $\left(\mathrm{C}^{-5}\right)$ and Attean (B-5) quad- 
rangles (fig. 2), the Silurian rocks were deposited near a shore which had pronounced local relief.

\section{PALEOGEOGRAPHY OF THE LATE SILURIAN-EARLY DEVONIAN}

Along the west side of the Moose River synclinorium in the Spencer Lake quadrangle (C-5), Boucot (written and oral communs., 1961) has found some evidence indicating that the pre-Upper Silurian rocks were emergent during much of Late Silurian and Early Devonian time. The evidence includes (1) the abundance of local discontinuous units of different ages separated by unconformities, (2) removal by erosion of Upper Silurian rocks prior to Becraft-Oriskany time and (or) onlap of Becraft-Oriskany rocks upon the pre-Upper Silurian rocks, (3) lithofacies relationships, (4) relief on the surface of the pre-Upper Silurian rocks, including the presence of possible fossil sea cliffs and sea stacks, and (5) intertonguing of Upper Silurian or Lower Devonian reef material, which contains large angular blocks of pre-Upper Silurian rock debris, with slate of the same age. Similar evidence has been found in the Attean quadrangle (B-5). In addition, Boucot (1962) has cited the general absence of upper Ludlow and lower Gedinnian units throughout the region as suggestive of a general emergence during this period.

Along the west side of the Boundary Mountain anticlinorium, slate of probable Early Devonian age rests directly upon the pre-Upper Silurian rocks. The absence of the conglomeratic or calcareous Upper Silurian units could be the result of a major fault or of removal by erosion in Early Devonian time. More likely, however, the absence of the Upper Silurian units results from the contrasting relations, along the east and west sides of the anticlinorium, of the position of the folded Upper Silurian shoreline and the present erosion surface. The exposure of Upper Silurian units with near-shore characteristics on the east side of the Boundary Mountain anticlinorium represents a coincidence between the locations of the deformed Upper Silurian shoreline and the present erosion surface; the absence of these nearshore deposits on the west side results from the onlap of the Lower Devonian slate facies onto the pre-Upper Silurian surface. The Upper Silurian near-shore deposits on the west limb, if originally present, are now below the present erosion surface.

\section{LOWER DEVONIAN ROCKS}

Several lithologic facies have been distinguished within the Devonian rocks. (See fig. 2.) Dark-gray argillaceous sandstone, containing minor gray slate and felsic volcanic rock, within the Moose River synclinorium makes up the Tarratine and Tomhegan Formations (the sandy facies of sedimentary rocks in fig. 2) and contains abundant fossils of Schoharie and Becraft-Oriskany age. Slate in and adjacent 
to the Moose River synclinorium (Seboomook Formation, the slaty facies of sedimentary rocks in fig. 2) contains fossils of BecraftOriskany and New Scotland age. No fossils have been found in the sandy facies within the Frontenac synclinorium (Frontenac Formation, the sandy facies in fig. 2), which consists predominantly of massive argillaceous sandstone containing minor slate and volcanic rock. The western unit (the slaty facies in fig. 2) in the Frontenac synclinorium is characterized by argillaceous and arenaceous limestone, slate, and sandstone and contains Early Devonian (New Scotland) fossils at its base, in rocks similar to the Silurian rocks described above.

The slate unit in the northeastern part of figure 2 is interpreted to be overlain by the sandy facies of both the Frontenac and the Moose River synclinoria, but the slate and sand facies may also be in part laterally equivalent. Although all the fossils found in these widespread dark-gray slate, sandstone, and limestone units are Early Devonian in age, the age of these rocks may locally extend upward into the Middle Devonian and downward into the Late Silurian.

\section{POST-EARLY DEVONIAN METAMORPHISM AND INTRUSIVE ROCKS OF EARLY DEVONIAN OR YOUNGER AGE}

The pre-Upper Silurian, the Upper Silurian, and the Lower Devonian rocks have all undergone regional metmorphism of the chlorite grade in the northern and western part of the area and of higher grade to the southeast. Hornblende diorite and gabbro masses intrude the Lower Devonian rocks, especially the sandy facies of the Frontenac synclinorium, and seems to have been somewhat affected by the regional metamorphism. Plutonic rocks, predominantly medium-grained biotite quartz monzonite and granodiorite but including some more mafic rocks, intrude all the metasedimentary units and are surrounded by contact-metamorphic aureoles. Isotopic ages are available for metamorphic or igneous minerals from several units (Hurley and others, 1959). These ages suggest that the regional metamorphism and the intrusion of the Devonian plutons ocurred nearly simultaneously in late Early or Middle Devonian time. The metamorphism, the intrusion, and the folding are all assigned to the Acadian orogeny. Although the Mount Megantic stock, the circular stock in quadrangle C-2 (fig. 2), is grouped with the Devonian intrusive rocks for purposes of construction of figure 2, radiometric age data indicate that the stock is Cretaceous in age (Lowden, 1960, 1961; Hurley, 1960; and Fairbairn and others, 1963).

\section{NATURE OF THE TACONIG OROGENY IN WEST-CENTRAL MAINE}

Several lines of evidence clearly indicate a pre-Late Silurian deformation in this area; however, it can only be inferred that this was the Taconic orogeny. 
Upper Ordovician and Lower Silurian rocks are absent in this area, and a widespread, apparently angular, unconformity lies above the pre-Upper Silurian rocks. Although the distribution of pre-Upper Silurian rocks is not known in detail, a continuous sequence of these units seems to extend from northwest to southeast, without major repetition, transversely across the Boundary Mountain anticlinorium and Moose River synclinorium that were formed during the Acadian orogeny. (See fig. 2.) At the south end of the Moose River synclinorium, steeply dipping pre-Upper Silurian rocks are apparently truncated, in an angular relation, by the overlying, less steeply dipping, Upper Silurian and Lower Devonian rocks. In addition, the rather coarse-grained Attean Quartz Monzonite, inferred to be Cambrian or Ordovician in age, was apparently unroofed and rather deeply eroded before Upper Silurian rocks were deposited over it. Furthermore, relict sillimanite, partly altered to white mica, and garnet occur locally within the preUpper Silurian granofels unit in the Spencer Lake and Attean quadrangles. This high-grade metamorphism cannot be attributed to the Middle Devonian regional metamorphism, which only attained chlorite grade in this area, nor does high-grade metamorphism seem to be related to any intrusive mass.

All these relations seem to indicate a pre-Late Silurian orogeny of major proportions involving metamorphism of sillimanite grade and major deformation and uplift. The intrusion of the Attean Quartz Monzonite may possibly be related to the same event. Future investigations may delimit the time of orogeny more closely; on the basis of present evidence, however, it is inferred to be the Taconic and will be referred to as such in this report.

\section{GEOMORPHOLOGY}

The Attean quadrangle is within the Boundary Mountains (Fenneman, 1938, p. 346), a range which extends from the White Mountains of northern New Hampshire northward along the Quebec-Maine border. Southwest of the Attean quandrangle, the range is a maturely dissected highland area containing many peaks between 3,000 and 4,000 feet in altitude. A series of east-northeast-trending ridges extends along the international boundary and across the extreme northern part of the Attean quadrangle. Boundary Bald Mountain, just northeast of the Attean quandrangle, is the highest peak (3,640 ft alt) in this series of ridges, which disappears abruptly a few miles to the east. An area of more subdued relief extends from the central part of the Attean quadrangle eastward along the Moose River.

The highest peak in the Attean quadrangle, No. 5 Mountain, has an altitude of 3,168 feet and a relief of 1,988 feet along its steep east face. Much of the southern and central part of the area, which includes most 
of the lakes and the course of Moose River, has an average altitude of approximately 1,200 feet and a subdued relief of several hundred feet. No. 5 Mountain (3,168 ft), No. 6 Mountain (3,280 ft), Attean Mountain $(2,442 \mathrm{ft})$, Sally Mountain (2,221 ft), and Burnt Jacket Mountain $(2,280 \mathrm{ft})$ rise conspicuously above this region of subdued relief. A triangular area having several hundred feet of relief rises gradually northward from an altitude of about 1,200 feet near Jackman to one of about 1,800 feet; it includes most of Dennistown. Slidedown Mountain $(2,691 \mathrm{ft})$ and Sandy Stream Mountain $(2,869 \mathrm{ft})$ are prominent peaks in the series of east-northeast-trending ridges in the extreme northern part of the quadrangle and along the international boundary.

The international boundary marks the divide between the Kennebec and St. Lawrence drainages. Most of the area drains into Moose River and thence to Moosehead Lake and the Kennebec River, but Boulder and Whipple Ponds in the extreme southeast section drain to Spencer Stream and thence to the Dead River and the Kennebec River. Wood Stream, Sandy Stream, and Barrett Brook are the major tributaries of Moose River in the area. Much of the Attean quadrangle is poorly drained, owing to glacial deposits and to the low gradient of Moose River. Presently, the flow of water on Moose River and its tributaries in the area is not artificially controlled. The dams shown on the topographic map on Barrett Brook, Wood Stream, Stony Brook, and Sandy Stream are ruins of sluice dams that were used to control the flow of water for driving logs on these streams and on Moose River. Dams have been built on the small pond west of Crocker Pond and on Crocker Pond, and a penstock has been built to deliver water from Crocker Pond to a hydroelectric plant in the valley to the east.

A striking correlation exists between the topography and both the bedrock and the surficial geology. An area underlain by pre-Upper Silurian granofels in the southwestern and west-central part of the quadrangle is marked by very knobby topography. An area underlain by pre-Upper Silurian granitic rock in the southeastern part is much smoother and rather featureless owing to extensive cover of surficial deposits. In the areas north of Holeb Pond and on mountain tops, glacial plucking of the jointed rock has produced a knobby rectilinear pattern. The area underlain by Devonian slate shows on the map as rather smooth ridges between the south-flowing streams. In the vicinity of Beaver Pond, a marked contrast can be seen between the topography over the slate and the knobby terrain underlain by the granite. However, the apparently smooth north-trending ridges actually consist of small closely spaced east-northeast-trending ridges parallel to bedding and cleavage. These cross ridges are concealed by a heavy growth of hardwood in this area. The mountains in the north also consist of nar- 
row east-northeast-trending ridges; narrow valleys 40-150 feet deep between ridges are not uncommon, although not expressed on the topographic map. The cross ridges show clearly on aerial photographs because the darker conifers are most abundant on the crests and north slopes of the ridges. The ridges can also be seen clearly from U.S. Route 201 near the north edge of the quadrangle. Wood Pond seems to occupy a depression caused by the weathering of a granitic stock.

Throughout the area the lower slopes, especially the northwest slopes, of hills have been modified by thick accumulations of glacial till, producing a smoother topography. The low-lying areas in the southeast are underlain by bouldery till and have an extremely hummocky topography. The areas of outwash near Jackman and Holeb are flat, but the outwash area along Sandy Stream is hummocky. The ice-channel deposits form distinctive linear ridges.

\section{BEDROCK GEOLOGY}

\section{PRE-UPPER SILURIAN ROCKS}

Pre-Upper Silurian rocks occur throughout the central and southern part of the area and occupy somewhat more than half the Attean quadrangle. (See pl. 1.) They are overlain unconformably by fossiliferous Upper Silurian and Lower Devonian units. The oldest of the preUpper Silurian units is the granofels unit, which is a complex of quartzofeldspathic metasedimentary rocks. The unit has been intruded successively by diorite, the Attean Quartz Monzonite, quartz porphyry dikes, aplitic quartz monzonite, and mafic dikes, all pre-Late Silurian in age. In many places throughout the area, all these rocks have undergone extensive alteration, probably during the post-Early Devonian regional metamorphism.

\section{GRANOFELS UNIT}

The granofels unit is the same as the pre-Silurian complex mapped by Marleau (1958b, p. 20) in adjacent Quebec.

The granofels unit crops out in the southwestern part of the Attean quadrangle and has been observed in reconnaissance in continuous outcrop from the Woburn area to the Attean area; it underlies much of the Chain Lakes quadrangle, the southeast corner of the Skinner quadrangle, and the western side of the Spencer Lake quadrangle (fig. 1.). In present usage, other pre-Upper Silurian rocks which crop out in the Kennebago Lake quadrangle and east of the Moose River synclinorium are not included in the granofels unit.

Typical granofels of this unit is well exposed on the steep slopes north of Barrett Pond (SW-0.4, 1.8) and in the vicinity of McKenney Pond (WC-0.7, 1.5). The granofels crops out on a graveled logging 
road that traverses the northwest corner of the Spencer Lake quadrangle and northeast corner of the Chain Lakes quadrangle; it is well exposed in roadcuts on State Route 4 on the north side of Chain Lakes.

The unit consists of quartzofeldspathic granofels, but its outcrop area includes masses of diorite too small to map. These small diorite masses are similar to the larger masses shown separately on the geologic map and described in the next section. The unit is chiefly a finegrained to dominantly medium-grained quartzofeldspathic granofels or gneiss that contains approximately 15 percent white mica, biotite, and chlorite, which are visible in hand specimen. The rock is greenish gray on a fresh surface and weathers to white or light gray, but the surface is almost invariably dark brown or gray stained and lichen coated. Lithic fragments, ranging from 0.5 inch to 20 inches in diameter, occur in most outcrops and locally are very abundant, forming as much as 15 percent of the rock. Many rock fragments are now merely clots of mafic minerals, but quartz "balls," hornblende-plagioclase rock, greenstone, and quartz-epidote schist are abundant.

The granofels is characteristically massive and extensively fractured. Bedding is uncertain and a measurable gneissic foliation is formed in only a few places. Fractures occur predominantly in local sets and have irregular surfaces. Some fractures have slickensides and elongate aggregates of platy minerals on their surfaces.

Thin-section study has indicated that the granofels consists of nearly equant grains of quartz and feldspar, commonly about 1 millimeter $(\mathrm{mm})$ in diameter. A considerable range in grain size is usually present in most specimens, however, and some specimens have a distinct bimodal distribution. Grain contacts are extremely sutured. Quartz has undulatory extinction, and a few grains have been fractured; but cataclastic textures are not present. Biotite and white mica are interstitial to the granular minerals, commonly in small clots.

Typical granofels consists of $40-50$ percent quartz, 30-50 percent feldspar and its alteration products, and 10-20 percent biotite, white mica, chlorite, and clinozoisite-epidote group minerals. Estimated mineral content from thin sections of typical granofels are given in table 1. Feldspar contains, or commonly is completely altered to, aggregates of very fine grained white mica, clinozoisite, and rare carbonate. Most feldspar seems to have been plagioclase, but potassium feldspar was found in several specimens. The $\beta$ refractive index of the relict plagioclase, relative to that of quartz and balsam, indicates that the plagioclase commonly has a composition of $\mathrm{An}_{20-25}$. Maximum extinction angles greater than $20^{\circ}$, measured on relict albite twinning in several specimens, indicate that the plagioclase may have been more calcic before alteration. 
TABLE 1.-Estimated modes of the granofels unit, Attean quadrangle, Maine

[Volume percent]

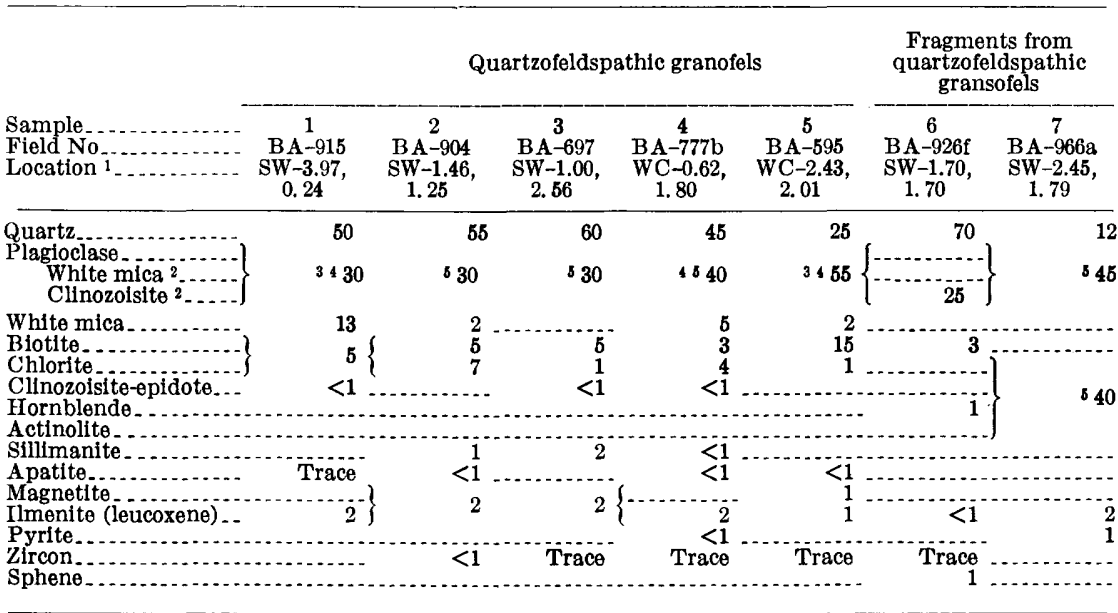

1 Explanation in description of fieldwork.

2 Plagloclase alteration mineral.

3 Moderate alteration.

${ }^{4} \mathrm{An}_{24}$.

5 High alteration.

The biotite is red brown, brown, and rarely green in plane-polarized light; it is partly altered to chlorite, white mica, and titanium minerals (ilmenite, rutile, sphene, and leucoxene), and a small amount has been altered to a pale-green biotite. Chlorite, biotite, and white mica occur in parallel intergrowths with each other; the chlorite and white mica grade into biotite along the cleavage planes. All the chlorite seems to have formed during the alteration, but part of the white mica occurs as larger plates, like the relict biotite, and was apparently part of the rock before alteration. Chlorite has a negative sign, a positive sign of elongation, and abnormal violet or blue interference colors, which indicate that it contains more iron than magnesium (Albee, 1962). Magnetite, ilmenite, rutile, apatite, and zircon are also present in small amounts.

A few specimens contained rather abundant horniblende, and several finer grained specimens contained abundant clinozoisite-epidote. Two specimens collected adjacent to the diorite contact ( $\mathrm{SW}-3.55$, 1.45) seem relatively less altered than those collected elsewhere. In these, red-brown biotite is unaltered, little or no chlorite is present, and the feldspar contains a rather small amount of white mica.

Six specimens contained small amounts of fine-grained fibrous sillimanite occurring in small clots associated with biotite and fine-grained white mica. In one specimen, the sillimanite is clearly within a lithic fragment, about $25 \mathrm{~mm}$ thick, consisting of quartz, potassium feldspar, biotite, and fibrolitic sillimanite. This fragment contained a sufficient 
amount of sillimanite to separate out and verify its identity by $\mathrm{X}$-ray diffraction methods. Clots of sillimanite were also found within very fine grained aggregates of white mica or white mica and chlorite, which might be interpreted as highly altered detrital feldspar or biotite grains. However, other clots of sillimanite occur within the matrix of the rock, making it seem impossible to ascribe a detrital origin to the sillimanite. Because sillimanite does occur in the matrix, the sillimanite in the detrital fragments may also have formed during metamorphism; a larger amount was found in the fragments simply because the fragments were more aluminous than the matrix.

The lithic fragments are difficult to identify in the field. The most abundant types are fine- and medium-grained mafic fragments. Quartz "balls" consisting of nearly spherical aggregates of rather clear quartz, much like vein quartz in appearance, are also abundant. Foliated inclusions that consist mainly of quartz were noted in many outcrops; one such inclusion contained a small tight fold. Most of the fragments are 1-2 inches thick and subrounded to subangular, but fragments as much as 20 inches thick were seen. A wide variety of inclusions may be seen in large outcrops near Barrett Brook (SW-1.70, 1.70; SW-2.45, 1.79). A more accessible outcrop near Holeb (SW-1.45, 5.25) contains many fragments, but nearly all are mafic.

Thin sections of 15 fragments were studied; eight consisted chiefly of hornblende and plagioclase and their alteration products; two, of actinolite, chlorite, and plagioclase; four, of quartz and epidote; and one, of quartz and plagioclase. The quartz-bearing fragments are foliated and thinly layered. One foliated fragment contained a tight fold, indicating that the foliation is predepositional. The quartzepidote rock seems to have formed by alteration of the quartz-plagioclase rock, and hornblende grains contain cores of pyroxene in several of the hornblende-plagioclase fragments.

An unusual cobble conglomerate that contains clasts of mafic rock is exposed along the Scott Paper Co. road in the northwestern part of the Spencer Lake quadrangle (NW-3.2, 3.4). The cobbles in this conglomerate are rather abundant and closely packed; the predominant lithology is hornblende-plagioclase rock. Some mafic cobbles are themselves fragmental rock. The matrix of this conglomerate closely resembles the typical granofels unit; it is quartz rich and contains lithic fragments similar to those found in the granofels. Reaction rims containing biotite, chlorite, quartz, and garnet separate some of the mafic fragments from the matrix. Many fragments are cut by quartz-feldspar veins that closely resemble the matrix in texture and mineral composition. The areal extent of this rock in the Spencer Lake quadrangle is unknown, but it seems to correspond to a 4-mile-long northeast-trending magnetic high on the aeromagnetic map of Hurley and Thompson 
(1950). This rock does not extend into the Attean quadrangle, but several outcrops of granofels that contain many large mafic fragments occur along the shores of Long Pond (WC-1.05, 1.95).

The lack of layering apparent homogeneity, and high feldspar and low muscovite content give the granofels the general appearance of a granodiorite. No bedding or thick layering was noted in the unit within the Attean quadrangle, although rarely the rock has a poorly formed gneissic layering. Marleau (1958b, p. 21), however, describes layers of pure metaquartzite alternating with layers of granofels along the international boundary. Also, Hurley and Thompson (1950) and Boucot $(1961$, p. 185) describe several different rock types in the Chain Lakes and Spencer Lake quadrangles; these rocks would seem to be within the granofels unit if the tentative genesis of the unit offered below is correct.

The granofels was probably a sedimentary rock which underwent metamorphism as high as the sillimanite grade prior to Late Silurian time and retrograde alteration during the metamorphism which affected the Devonian rocks of this area. The inference of a sedimentary origin is based upon (1) mineral composition, particularly the high content of quartz associated with high plagioclase and low potassium feldspar contents (2) the variety and widespread distribution of lithic fragments and (3) poorly preserved relict clastic textures.

The mafic lithic fragments possibly were deposited as fragments of mafic volcanic rock which were subsequently altered to the present hornblende-plagioclase assemblage by the pre-Late Silurian metamorphism. The mafic cobbles, which are themselves fragmental, may have been fragments of a volcanic breccia. Such a close association with volcanic source areas could explain many peculiar features of the granofels unit, particularly the massive nature and high plagioclase content in association with a high content of quartz. The matrix of a sedimentary rock that contains abundant volcanic fragments would be expected to contain substantial amounts of feldspathic volcanic detritus; moreover, such a rock would tend to be rather homogeneous and poorly sorted, but hardly devoid of internal layering. The apparent lack of obvious internal layering, relict or otherwise, within the granofels unit remains to be adequately explained. The preponderance of quartz detritus in sediments with a requisite mafic volcanic provenance is obviously problematic also.

\section{DIORITE}

Diorite crops out in two large masses in the southwest part of the Attean quadrangle. The southernmost diorite mass contains abundant inclusions of granofels near its contact $(\mathrm{SW}-2.45,1.85)$ and some 
inclusions well within the mass. Contacts of the northern mass were located primarily by aeromagnetic data.

Many small diorite masses also crop out within the granofels unit, but they are too small to show on the map. Many of these small bodies are merely isolated outcrops whose relations to the granofels cannot be seen, but others are clearly tabular dikes or sills. In several places within the unit, admixtures of diorite and granofels crop out in widely different proportions and in irregular patches of widely different sizes. Such admixed rocks are well exposed on the summit and south slope of an unnamed mountain in the west-central part of the area (WC-3.4, 2.7), where the relation seems to be that of an irregular diorite intrusive rock that contains abundant inclusions of granofels, further complicated by later intrusions of dikes and epidote-quartz-feldspar veins. Similar relations between diorite and granofels, although further complicated by intrusion of Attean Quartz Monzonite, are found in a roof pendant of that pluton (SC-2.1, 1.3) and on the west summit ridge of Burnt Jacket Mountain (C-0.8, 2.8).

The diorite is a fine- to medium-grained dark-greenish-gray rock that consists mostly of plagioclase and hornblende. Single outcrops have varied degrees of alteration caused by the post-Early Devonian metamorphism. Outcrops of least altered granular diorite contain patches and thin lenses of very fine grained dark-greenish-gray rock that has a faint foliation or a poor conchoidal fracture. Irregular veins and patches of quartz and epidote are abundant.

The least altered diorite is dark greenish gray (commonly speckled dark green and white in hand specimen), medium grained, and granular. The original rock consisted of approximately 60 percent plagioclase and 35 percent hornblende, as determined from the least altered varieties; minor constituents probably included magnetite, ilmenite, apatite, and zircon. Estimated modes of typical specimens are given in table 2.

The least altered diorite consists of equant grains of plagioclase ( $\approx 1 \mathrm{~mm}$ thick) and somewhat larger grains of hornblende, which commonly contain inclusions of plagioclase. Hornblende has the following properties: $2 V(-) \approx 75^{\circ} ; Z \wedge c \approx 25^{\circ}$; and pleochroism, $\mathrm{X}$, light yellow; Y, dark green; and $\mathrm{Z}$, blue green. Hornblende has been partly altered to aggregates of chlorite, clinozoisite-epidote, fibrous actinolite, and, less commonly, to opaque minerals and biotite. The chlorite has a positive sign and abnormal brown interference colors, which suggest an iron to magnesium ratio of somewhat less than one. The actinolite $\left(\mathrm{Z} \wedge c \approx 20^{\circ}\right)$ occurs as light-green fine needles. 


\section{TABLE 2.-Estimated modes of diorite, Attean quadrangle, Maine}

[Volume percent]

\begin{tabular}{|c|c|c|c|c|c|}
\hline \multirow[b]{2}{*}{$\begin{array}{l}\text { Sample } \\
\text { Field No } \\
\text { Location }{ }^{1}\end{array}$} & \multicolumn{4}{|c|}{$\begin{array}{c}\text { Diorite from large mass in southwest corner, } \\
\text { Attean quadrangle }\end{array}$} & \multirow{2}{*}{$\begin{array}{c}\text { Diorite from } \\
\text { smaller mass } \\
\text { (not shown on } \\
\text { pl. 1) within the } \\
\text { quartozofelds- } \\
\text { pathic granofels } \\
5 \\
\text { BA-986a } \\
\text { WC-3.37, } 2.71\end{array}$} \\
\hline & $\begin{array}{c}1 \\
\mathrm{BA}-404 \mathrm{a} \\
\mathrm{SW}-3.50,2.45\end{array}$ & $\begin{array}{c}2 \\
\text { BA-404b } \\
\text { SW-3.50, 2.45 }\end{array}$ & $\begin{array}{c}3 \\
\text { BA-930 } \\
\text { sW-2.90,2.00 }\end{array}$ & $\begin{array}{c}4 \\
\text { BA-964 } \\
\text { sw-2.00,1.94 }\end{array}$ & \\
\hline Quartz $\ldots \ldots$ & 1 & 5 & \multirow[b]{3}{*}{35} & 10 & \multirow{3}{*}{445} \\
\hline Plagioclase _. & 49 & & & \multirow{2}{*}{350} & \\
\hline $\begin{array}{l}\text { Clinozoisite }{ }^{2} \\
\text { White mica }\end{array}$ & 14 & & & & \\
\hline Hornblende & 30 & & $\begin{array}{l}5 \mathrm{~J} \\
50\end{array}$ & & \multirow{2}{*}{$\begin{array}{r}555 \\
\text { Trace }\end{array}$} \\
\hline Actinolite. . . & & 630 & 11 & 340 & \\
\hline $\begin{array}{l}\text { Chlorite } \\
\text { Clinozoisite-epidote }\end{array}$ & $<1$ & 1 & & Trace & Trace \\
\hline 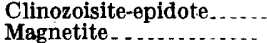 & 3 & $\begin{array}{l}620 \\
{ }^{6}\end{array}$ & & & \\
\hline Ilmenite (leucoxene) & & & 1 & $\alpha$ & - \\
\hline Rutile........... & $<1$ & & & & (n) \\
\hline $\begin{array}{l}\text { Apatite. } \\
\text { Zircon }\end{array}$ & Trace & & & & \\
\hline Pyrite......... & $<1$ & 1 & & $<1$ & $<1$ \\
\hline
\end{tabular}

Explanation given in description of fieldwork.

2 Plagioclase alteration mineral.

3 Ans5.

High alteration.

${ }^{5}$ Minor alteration.

iSchistose, original texture destroyed.

Plagioclase is highly altered, even in rocks in which the hornblende is virtually unaltered. In many specimens, plagioclase has been completely replaced by a fine-grained aggregate of zoisite-clinozoisite group minerals and white mica, but the feldspar twinning has been preserved by preferred orientation of the alteration minerals. In slightly altered plagioclase, white mica predominates over zoisiteclinozoisite; in highly altered plagioclase, zoisite-clinozoisite is more abundant. On the basis of several slightly altered specimens, the original plagioclase is inferred to have had a composition of about $\mathrm{An}_{55}$. Small amounts of quartz in many specimens are probably related to the alteration, but several specimens collected near the contact contain quartz which may be primary. Minor amounts of pyrite, sphene, and rutile are also related to the alteration.

Contact relations indicate that the main mass of diorite intrudes the granofels unit. However, a rock that has this texture and mineralogy can form either by crystallization from a melt or by metamorphism (Wasserburg and others, 1964), and no textural or mineralogical evidence indicates the precise method of formation of the present hornblende-plagioclase assemblage here. The diorite is older than the Attean Quartz Monzonite, which is probably younger than the preLate Silurian metamorphism, but no positive evidence was found to indicate that the diorite intrusion preceded the pre-Late Silurian metamorphism of the granofels unit. A possible explanation of the 
present diorite occurrence is that the main mass retained its original igneous texture and mineralogy when subjected to regional metamorphism, whereas some of the isolated bodies within the granofels unit were formed by metamorphism of fine-grained mafic volcanic rocks or dikes.

\section{ATTEAN QUARTZ MONZONITE}

The Attean Quartz Monzonite is herein adopted and is named for its excellent exposures along the shores of Attean Pond and on Attean Mountain in Attean Township. The type locality is along a line trending azimuth $250^{\circ}$ from the unnamed islands in the southwest part of Attean Pond (SE-1.14, 4.56) to the summit of Attean Mountain (SC-3.30, 4.02). Other reference localities of the unit are designated as follows: (1) Along a line trending azimuth $230^{\circ}$ from Holeb Falls (SC-3.12, 2.30) to the base of No. 5 Mountain west of the Tobey Ponds (SC-2.10, 1.34), and (2) along a line trending azimuth $313^{\circ}$ from a point on the north shore of Little Big Wood Pond (C-3.20,3.78) south of Sugar Berth Pond to the trail in the saddle at location (C-2.74, 4.23). Aplitic quartz monzonite (discussed in a following section) probably represents a late-stage facies of the Attean Quartz Monzonite, but the possibility remains that the rock could be much younger. Excepting one discrete body on Sally Mountain (SE-0.2, 5.5), the aplitic rock is mapped with the Attean Quartz Monzonite and is not shown by a separate symbol on the bedrock geologic map. (See pl. 1.)

The Attean Quartz Monzonite has a greater areal extent than any other unit in the Attean quadrangle; it crops out in a broad band north and east of the granofels unit. This band extends only a mile or so westward into the Skinner quadrangle (fig. 2, B-4), but it continues southeast of the Attean quadrangle, where quartz monzonite occupies the southwestern part of the Long Pond quadrangle (fig. 2, B-6), the northwestern part of the Pierce Pond quadrangle (C-6), and the northeastern part of the Spencer Lake quandrangle (C-5). A U.S. Geological Survey aeromagnetic map (Bromery and Gilbert, 1962) indicates that the small intrusive body on the west border of the Attean quadrangle extends only about a mile into the Skinner quadrangle. A magnetic low about 1.5 miles long in the Skinner quadrangle corresponds with outcrops of quartz monzonite at Skinner Station, and the pattern suggests that quartz monzonite may be present under the topographically low area in the west-central part of the Skinner quadrangle.

The amount of alteration caused by the post-Early Devonian metamorphism differs greatly from place to place; south of Little Big Wood Pond, the Attean Quartz Monzonite is only slightly altered 
compared to the quartz monzonite to the north and west, which is highly altered and has a cataclastic schistosity. The rock in these two areas will be described separately. Typical less altered quartz monzonite is exposed in the railroad cuts north of Attean Pond and on the shores of Attean and Holeb Ponds; outcrops accessible by road are on the road from Parlin Pond to Spencer Lake in the northeast part of the Spencer Lake quadrangle. Typical highly altered Attean Quartz Monzonite crops out in the vicinity of Smith Pond $(\mathrm{C}-0.37,4.82)$ on a logging trail which is on the extension of a driveable road from Crocker Pond to Wood Stream.

Intrusive relations in the border zone indicate that the Attean Quartz Monzonite is younger than both the granofels unit and the pre-Upper Silurian diorite. Such relations are well exposed on a peninsula and several islands in Holeb Pond (SC-0.16, 5.6), near Tobey Ponds (SC-2.2, 1.6 and 2.35, 1.75), and on the west summit of Burnt Jacket Mountain (C-0.6,3.3). Dikes of Attean Quartz Monzonite and aplite cut the granofels and the diorite, and inclusions of both the older rocks occur within the Attean Quartz Monzonite. Inclusions are generally found only a short distance into the quartz monzonite from the line mapped as the contact, but irregular masses and dikes of quartz monzonite and aplite occur well away from the contact. Widespread contact-metamorphic effects related to the intrusion of the quartz monzonite could not be discerned. The granofels and diorite seem somewhat coarser grained at the contact, and in detail, many of the contact zones show complex relations manifested by a wide array of rock types suggestive of partial assimilation. One contact-zone rock type, a twofeldspar rock high in hornblende and low in quartz, contains abundant inclusions and may represent quartz monzonite contaminated by reaction with the inclusions. Locally, lit-par-lit injection has occurred, resulting in alined lenticular inclusions separated by feldspathic rock apparently related to the quartz monzonite.

A distinct stratigraphic unconformity indicates that the Attean Quartz Monzonite is older than the metasedimentary rocks which rest upon it and contain Late Silurian fossils. This unconformity is well exposed along the south flank of Sally Mountain near the eastern summits and north of Little Big Wood Pond (C-2.74, 4.23) where, respectively, a coarse polymictic conglomerate and a granule conglomerate may be seen in contact with the quartz monzonite, which appears to have contributed appreciably to the clastic material.

An Ordovician(?) age is assigned to the Attean Quartz Monzonite in consideration of intrusive relationships, the unconformity, and radiometric age determinations described in a later section. 


\section{SOUTH OF LITTLE BIG WOOD POND}

In the area south of Little Big Wood Pond, the Attean Quartz Monzonite is only slightly altered. It is a mottled pink and green medium - to coarse-grained porphyritic quartz monzonite characterized by large phenocrysts of potassium feldspar. The rock consists of about equal amounts of quartz, pink potassium feldspar, and white or greenish plagioclase and about 5-10 percent mafic minerals. Except for the abundant joints, the rock is massive and essentially structureless, so that it forms generally smooth rounded outcrops. The potassium feldspar phenocrysts are notably alined in only a few places. Mafic inclusions are rare, but have a planar alinement in a few places. Structures that consists of a concentration of epidote in and adjacent to fractures commonly form a network which stands up above the weathered surface of the quartz monzonite.

The texture of the slightly altered quartz monzonite is rather uniform throughout the area; it is everywhere porphyritic and the grain size of the matrix is apparently uniform, although the maximum size of the tabular phenocrysts differs from outcrop to outcrop. Typical quartz monzonite is coarse grained and contains equant quartz and plagioclase grains, mainly $3-5 \mathrm{~mm}$ thick, and large tabular potassium feldspar phenocrysts $10-50 \mathrm{~mm}$ long.

Our best estimate of the overall composition of the Attean Quartz Monzonite is as follows: Quartz, 25-30 percent; potassium feldspar. 30-35 percent; plagioclase, $35-40$ percent; mafic minerals, 5-10 percent. The abundance of potassium feldspar phenocrysts differs from place to place within a single outcrop, so that it is difficult to estimate an average mode. Field observations and the average of the range of modes observed in 11 individual thin sections (table 3) suggest that quartz, potassium feldspar, and plagioclase are present in nearly equal amounts. Modes of three typical samples of quartz monzonite are also given in table 3 . These measurements were made by counting points under a lens; a 1/16-inch-spaced transparent dot pattern was used as a grid on a polished slab in which the potassium feldspar had been stained. In one of these samples, potassium feldspar is more abundant than plagioclase, but in the other two, plagioclase is more than twice as abundant as potassium feldspar. Modes for five individual slabs (table 3, samples 1-3) and inspection of other slabs indicate a distinct difference in composition among samples of the quartz monzonite, even at the scale of the slabs. However, the relative proportions of potassium feldspar and plagioclase in the measured mode of BA-766 (table 3, sample 2) correspond rather well with those of its norm (table 4). 
TABLE 3.-Modes and dominant grain sizes of the Attean Quartz Monzonite, Attean quadrangle, Maine

\begin{tabular}{|c|c|c|c|c|c|c|c|c|c|}
\hline \multirow[t]{2}{*}{$\begin{array}{l}\text { Sample } \\
\text { Field No No } \\
\text { Location } 1 . . .\end{array}$} & \multicolumn{3}{|c|}{$\begin{array}{c}\mathrm{1}^{\mathrm{B}}-647 \\
\mathrm{SC}-3.10,1.95\end{array}$} & \multicolumn{3}{|c|}{$\begin{array}{c}\stackrel{2}{\mathrm{BA}-766} \\
\mathrm{SE}-1.16,4.50\end{array}$} & \multirow{2}{*}{$\begin{array}{c}3 \\
\text { BA-578 } \\
\text { SW-3.82, 5.66 } \\
\end{array}$} & \multicolumn{2}{|c|}{11 thin sections } \\
\hline & Slab 1 & Slab 2 & Average & Slab 1 & Slab 2 & Average & & Average & Range \\
\hline \multicolumn{10}{|c|}{ Modes, in volume percent } \\
\hline 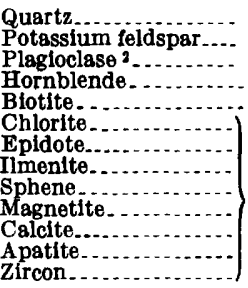 & $\begin{array}{l}25.8 \\
26.6 \\
40.6\end{array}$ & $\begin{array}{l}26.1 \\
11.7 \\
47.5\end{array}$ & \begin{tabular}{c}
26.0 \\
19.1 \\
34.0 \\
7 \\
2 \\
1 \\
1 \\
\hdashline Trace \\
Trace
\end{tabular} & $\begin{array}{l}21.0 \\
19.3 \\
46.5\end{array}$ & $\begin{array}{l}18.5 \\
22.3 \\
49.3 \\
\end{array}$ & $\begin{array}{c}19.9 \\
20.7 \\
347.9 \\
2 \\
6 \\
<1 \\
2 \\
1 \\
<1 \\
\text { Trace. }\end{array}$ & $\begin{array}{r}3 \\
<1 \\
<1 \\
<1 \\
<1 \\
<1 \\
<1\end{array}$ & $\begin{array}{l}30 \\
30 \\
35\end{array}$ & $\begin{array}{l}20-45 \\
19-40 \\
22-48\end{array}$ \\
\hline
\end{tabular}

Dominant grain gizes, in millimeters

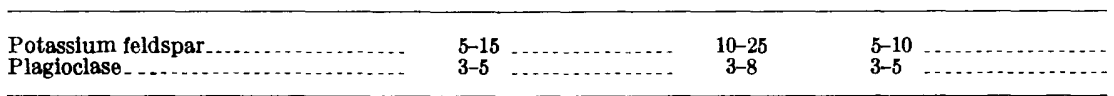

1 Explanation given in description of fieldwork.

2 Includes alteration products: white mica, "clay," and clinozoisite.

3 An31.

1. Typical Attean Quartz Monzonite; mode based on 2,670-point grid of 25 square inches on two polished and stained slabs from different specimens. Slab 1: 1,331 points over 12.5 square inches. Slab 2: 1,339 points over 12.5 square inches.

2. Typical Attean Quartz Monzonite; chemical analysis given in table 4 and potassium-argon age for biotite given in table 12. Mode based on a 2,449-point grid of 18 square inches on two pollshed and stained slabs cut from one specimen. Slab 1: 1,296 points over 12.5 square inches. Slab 2: 1,153 points over 5.5 square inches.

3. Typical Attean Quartz Monzonite; mode based on a 1,228-point grid of 7 square inches on a polished and stained slab.

4. Average and range of estimated modes for 11 thin sections of little-altered Attean Quartz Monzonite.

\section{TABLE 4.-Chemical analysis and CIPW norm of the Attean Quartz Monzonite, Attean quadrangle, Maine}

[Analyzed by methods described by Shapiro and Brannock (1956). Modes for sample BA-766 are given in table 3. Laboratory No. 156031; field Nos. BB-2526b and BA-766; location, 1 SE-1.16, 4.50]

Chemical analysis (weight percent)

$\mathrm{SiO}_{2}$

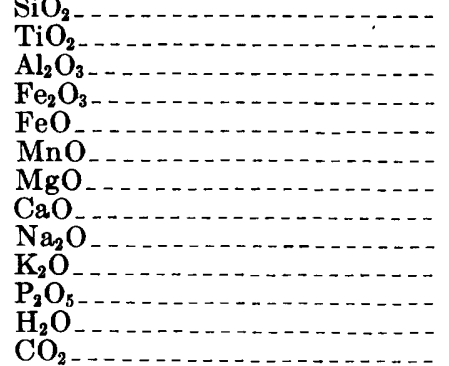

Total
70. 2 Magnetite.

CIPW norm

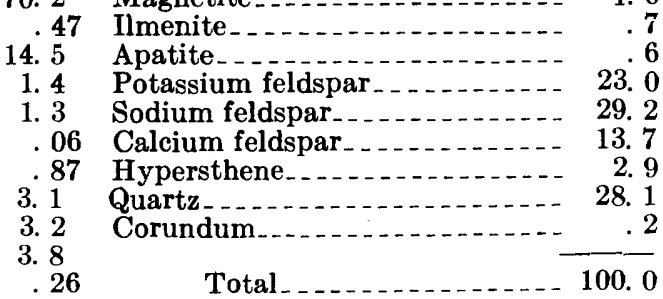

1 Explanation given in description of fieldwork. 
good enough to give well-defined basal spacings for the micaceous min-

The quartz monzonite south of 'Little Big Wood Pond has pronounced metamorphic alteration effects, even though it is characterized as relatively slightly altered. Thin granulated zones and epidote-filled fractures are abundant; the potassium feldspar is pink or reddish, and the plagioclase is commonly green. In thin section, one can see mortar texture, granulated zones, offset twin planes in feldspar, undulatory extinction in quartz, and alteration of mafic minerals and plagioclase. Figure 3 illustrates various degrees of alteration and cataclastic deformation.

The tabular potassium feldspar phenocrysts are commonly twinned according to the carlsbad law and rarely have well-formed rims of plagioclase. The potassium feldspar is a fine microperthite. X-ray diffraction patterns obtained with $\mathrm{Cu} K \alpha$ radiation have $(\overline{201)}$ peaks at $2 \theta$ values of $20.9^{\circ}-21.0^{\circ}$ and $22.0^{\circ}$, indicating the presence of potassiumrich and sodium-rich phases. Values for $\Delta 2 \theta$ of $\overline{13} 0-130$ ) are $0.65^{\circ}$ $0.7^{\circ}$, indicating that the mineral has an intermediate degree of triclinicity. The potassium feldspar is virtually unaltered compared to the plagioclase; the red color is apparently due to clouding by dustlike particles. In some specimens the sodium-rich phase of the perthite is more clouded than the potassium-rich phase.

Albite twinning and, less commonly, other types of twinning can be seen in the plagioclase, in spite of the intense alteration. Zoning is commonly reflected by differences in the amount of alteration. Plagioclase in three samples, the modes of which are given in table 3, has a composition $\operatorname{An}_{31}(\beta=1.548)$. The $\alpha$ index of plagioclase from another specimen was measured by a single-variation method on the universal stage; its composition is $\mathrm{An}_{31 \cdot 2}\left(\alpha=1.5443,2 \mathrm{~V} \gamma=96.0^{\circ}\right)$. X-ray diffraction patterns show a $(\overline{2} 01)$ peak at a $2 \theta$ of $22.0^{\circ}$, which indicates a low potassium content. A low structural state is indicated by $\Delta 2 \theta$

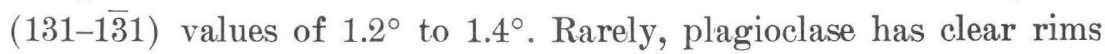
of albite.

In thin section the principal alteration products of the plagioclase appear to be "white mica," "clay," and clinozoisite-epidote. Attempts to check this mineralogy by X-ray diffraction methods were not entirely successful. Using a dental drill, plagioclase was removed from three of the stained slabs. The powder from this removed plagioclase was sedimented, and the finer grained material was given a preferred orientation by settling onto a glass slide. Three X-ray diffraction patterns obtained with $\mathrm{Cu} K \alpha$ radiation were then obtained from each of these prepared samples: (1) untreated, (2) after treatment with ethylene glycol, and (3) after heating to $500^{\circ} \mathrm{C}$. Because abundant plagioclase still remained in the samples, the preferred orientation was not 


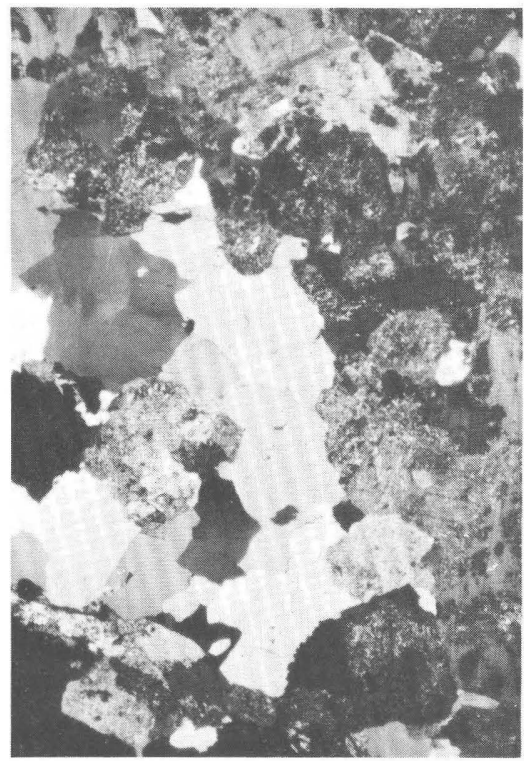

$A$

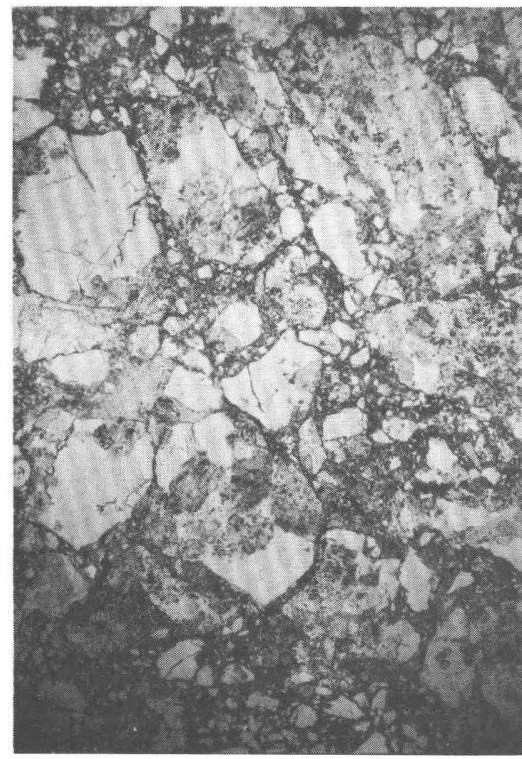

$C$

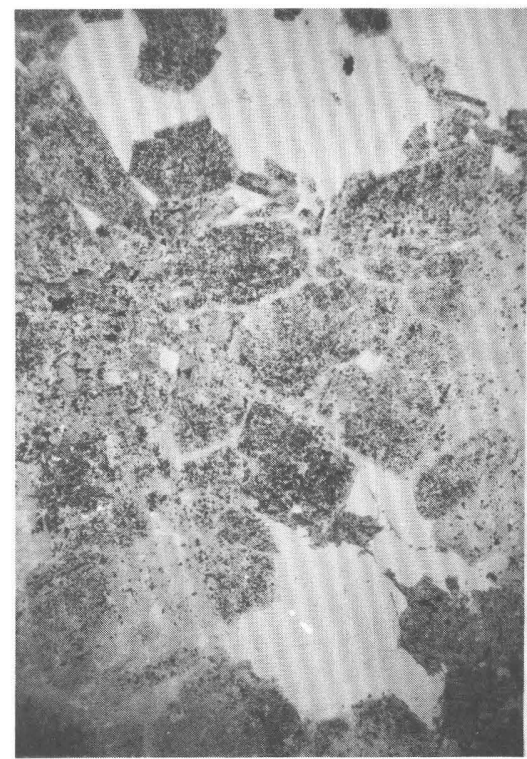

$B$

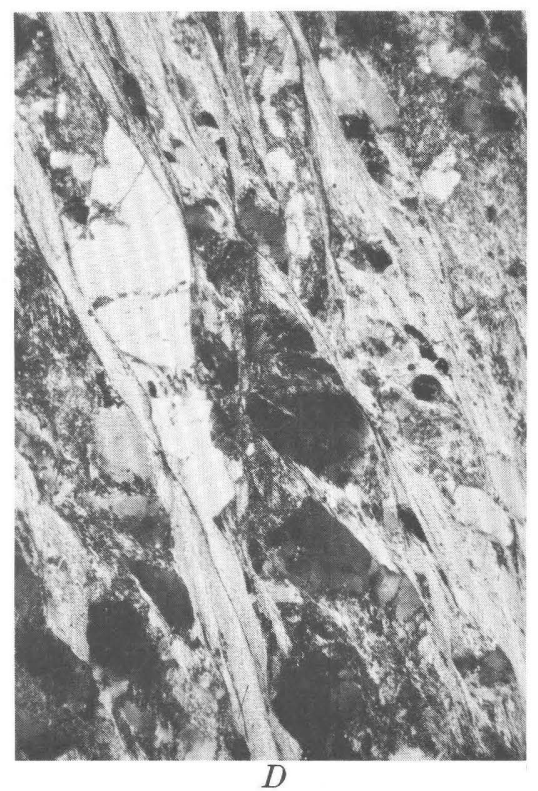

$5 \mathrm{~mm}$

Figure 3.-Photomicrographs showing alteration and cataclasis in the Attean Quartz Monzonite. A, Relatively unaltered rock with alteration only in plagioclase. Crossed polarizers. $B$, Highly altered rock with original texture preserved and no evidence of cataclasis. Plane-polarized light. $C$, Cata- 
erals. The untreated samples had a rather broad compound peak at a $2 \theta$ of $8.3^{\circ}$ to $9.1^{\circ}$ and several poorly defined possible peaks at slightly lower angles. The samples treated with ethylene glycol had a slight shift in the lower angle part of the broad peak and slightly better definition in the lower angle peaks. One sample had a poorly defined kaolinite (001) peak at a $2 \theta$ of $12.4^{\circ}$. Only the peak at a $2 \theta$ of $8.9^{\circ}$ remained after heat treatment. It was concluded that the alteration products are predominantly muscovite but that a small amount of kaolinite and possibly a mixed-layer muscovite-montmorillonite clay mineral may be present.

The primary mafic minerals probably included biotite and hornblende. Relict grains of hornblende and aggregates pseudomorphic after hornblende were noted in a few thin sections. No relict biotite was seen, but aggregates apparently pseudomorphic after biotite were observed in several thin sections. The presence of normative hypersthene and the absence of normative calcium pyroxene (table 4) suggest that the primary mafic mineral in that specimen should have been biotite rather than hornblende, but hornblende is present in the rock. The pseudomorphic mafic aggregates now consist predominantly of biotite, chlorite, and clinozoisite-epidote; minor amounts of tremolite, sphene, ilmenite, magnetite, white mica, and calcite may also be present.

Mafic inclusions occasionally found within the Attean Quartz Monzonite consist of quartz, altered plagioclase, and aggregates of biotite, chlorite, clinozoisite-epidote, and some other minerals; the external forms of the aggregates suggest alteration from a hornblende-rich rock.

\section{NORTH AND WEST OF LITTLE BIG WOOD POND}

North and west of Little Big Wood Pond, the Attean Quartz Monzonite is highly altered and locally has a cataclastic schistosity. Throughout this area the quartz grains stand out prominently on the weathered surface and give it a "hobnailed" appearance. In the eastern part of this area, the quartz grains are generally rather equant and have very irregular surfaces; but in the western part of the area, the quartz grains are lenticular and alined. The cataclastic schistosity is best formed near the northeast-trending contact with the younger rocks in the western part of the area; here both the micaceous alteration minerals and the quartz grains are alined, giving the rocks a true micaceous schistosity (fig. $3 D$ ).

clastically deformed rock, but relatively little alteration of feldspar. Planepolarized light. $D$, Cataclastic schistosity combining cataclasis, high alteration, parallel preferred orientation of the micaceous alteration products. Crossed polarizers. 
Fresh surfaces of this rock are green, and large potassium feldspar phenocrysts are only locally prominent. Potassium feldspar was present in most thin sections of slightly altered rock, but in thin sections of more altered rock the former presence of potassium feldspar could not be verified, either by texture or by differences in the mineralogy of alteration aggregates. Thus, the highly altered Attean Quartz Monzonite in this northern area may possibly have been originally richer in plagioclase, and more equigranular and finer grained, than the quartz monzonite in the southeast.

Mortar structure, undulatory extinction, granulation in quartz, and other textures indicative of cataclasis are extremely well formed (figs. $3 C, D)$. The primary minerals-hornblende and biotite, plagioclase, and potassium feldspar-are similar to those found in the less altered quartz monzonite south of Little Big Wood Pond; their relative amounts of alteration are also similar, and the same secondary minerals are present.

Samples of this rock were prepared and analyzed in the same manner as the samples from south of Little Big Wood Pond. Fine-grained material was separated by sedimentation from three samples of highly altered quartz monzonite and was settled with preferred orientation on glass slides. Three $\mathrm{X}$-ray diffraction patterns obtained with $\mathrm{Cu} K \alpha$ radiation were then taken of each sample: (1) untreated, (2) after treatment with ethylene glycol, and (3) after heating to $500^{\circ} \mathrm{C}$. The presence of a sharp peak at a $2 \theta$ of $12.5^{\circ}$ which disappears after heat treatment, and the absence of a peak at a $2 \theta$ of $6.30^{\circ}$ indicate that kaolinite is present, and chlorite absent, in this separated material. Chlorite is present in the rock, however. The muscovite (001) peak at a $2 \theta$ of $8.9^{\circ}$ is broad, and in two of the samples a second peak occurs at a $2 \theta$ of $8.5^{\circ}$, which shifts toward smaller angles after ethylene glycol treatment and disappears after heat treatment. This relation suggests the presence of muscovite (or illite) and mixed-layer muscovite-montmorillonite. Another peak at a $2 \theta$ of $11.6^{\circ}$, which disappears after heat treatment, may indicate the presence of metahalloysite in two of the samples.

\section{APLITIC QUARTZ MONZONITE}

Rock that is comparable to the aplitic quartz monzonite was found to be associated with quartz porphyry at Catheart Mountain (Long Pond quadrangle; fig. 1) subsequent to completion of fieldwork in the Attean quadrangle. At Catheart Mountain intensive exploration for copper-molybdenum mineralization in a quartz porphyry series has elucidated the relations between the Attean Quartz Monzonite and later crosscutting intrusive rocks more clearly than was possible in 
the Attean quadrangle. The field relationships and preliminary isotope age studies at Catheart Mountain indicate that the quartz porphyry series, including the aplitic quartz monzonite, may be much younger than the Attean Quartz Monzonite.

Aplitic quartz monzonite dikes, generally less than a foot thick, are common in the Attean Quartz Monzonite south of Little Big Wood Pond; in addition, aplitic quartz monzonite forms a large part of the rock on the south and southeast side of the west peak (SE-0.2, 5.5) and central ridge of Sally Mountain. The aplitic quartz monzonite may be gradational into quartz porphyry at Sally Mountain (described in the next section), but the boundary relations of the two rocks are obscured by cover and faulting.

The aplitic rock is fine grained and equigranular and consists of essentially the same minerals as the Attean Quartz Monzonite, but mafic minerals are less abundant than in the coarser grained quartz monzonite. Cataclastic texture is common, and the feldspars of the aplitic rock are commonly intensely altered.

\section{QUARTZ PORPHYRY}

Quartz porphyry is present as dikes throughout the granofels unit, but these dikes are more abundant in areas near the Attean Quartz Monzonite, and one irregular body occurs within the Attean Quartz Monzonite on Sally Mountain. Locations of observed dikes and the Sally Mountain body are shown on the geologic map. (See pl. 1.) The dikes rarely occur within the Attean Quartz Monzonite, however, and all these are very near the contact with the granofels. Quartz porphyry dikes are especially abundant in the area around Long and Mud Ponds, and a typical outcrop is on a point on the north shore of Long Pond (WC-1.10, 1.90). More accessible outerops are on the fire-tower trail near the top of No. 5 Mountain (SC-1.36, 0.02) and in the saddle between the south summits of No. 5 Mountain (Spencer Lake quadrangle, $\mathrm{NC}-1.47,5.50)$. The trail leaves a driveable road at an altitude of 1,700 feet on the stream north of Rock Pond; the road is reached via the road from Parlin Pond to Spencer Lake. The quartz porphyry on Sally Mountain is well exposed on a small knob (SE-0.49,5.60) and in several other less extensive outcrops about 0.3 mile southeast.

The quartz porphyry of the dikes within the granofels unit is massive and without planar structure and is present both as tabular bodies several feet thick and as larger irregular masses. The rock consists of subhedral phenocrysts of quartz and feldspar, set in a very fine grained light-colored matrix. The quartz phenocrysts occur as subhedral hexagonal dipyramids $3-6 \mathrm{~mm}$ in greatest dimension; this crystal habit suggests that they crystallized as high quartz. Two feld- 
spars oocur as blocky phenocrysts; plagioclase is greenish and potassium feldspar is pinkish due to differences in the alteration minerals. The matrix is light green, but weathering forms a rather thick tan chalky rind.

The dike rock consists of about 10 percent quartz phenocrysts, 15 percent feldspar phenocrysts, 10 percent mafic minerals, and 65 percent quartz-feldspar groundmass (table 5). The quartz phenocrysts, although subhedral, have smooth "corrosion" contacts with the matrix. The potassium-feldspar is a fine microperthite similar to that in the Attean Quartz Monzonite. The plagioclase commonly is highly altered, but a reliable index was obtained from one specimen and indicated a composition of $\mathrm{An}_{25} \quad(\beta=1.545)$. Although potassium-feldspar is conspicuous in some of the dikes because of its coarse habit, it only makes up 5-7 percent of the average rock, and potassium-feldspar phenocrysts were absent in about half the specimens studied. The matrix is commonly spherulitic and granophyric, but in some specimens it is granular and has a grain size of less than $0.1 \mathrm{~mm}$. Stained thin sections and $\mathrm{X}$-ray analyses indicate that the matrix consists

TABLE 5.-Estimated modes and dominant grain sizes of quartz porphyry dikes, Attean quadrangle, Maine

\begin{tabular}{|c|c|c|c|c|c|}
\hline $\begin{array}{l}\text { Sample } \\
\text { Field No }\end{array}$ & BA-1077 & $\stackrel{2}{2}$ & $\begin{array}{c}3 \\
\text { BB-2182a }\end{array}$ & BA -487 & $\stackrel{5}{10 \text { thin sections }}$ \\
\hline Location ${ }^{1}$ & $\begin{array}{l}\mathrm{SC}-1.35 \\
0.02\end{array}$ & $\begin{array}{l}\text { SW-1.62, } \\
2.52\end{array}$ & $\begin{array}{c}\text { WC-0.82, } \\
1.70\end{array}$ & $\begin{array}{l}\text { WC-3.38, } \\
2.02\end{array}$ & Average Range \\
\hline
\end{tabular}

Modes, in volume percent

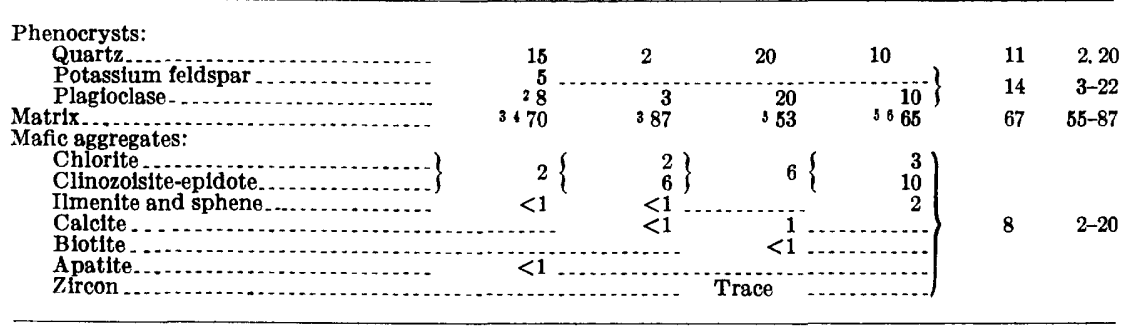

Dominant grain gizes, in millimeters

Phenocrysts $\ldots \ldots \ldots \ldots \ldots \ldots \ldots \ldots$
Matrix...................

1 Explanation given in description of fieldwork.

2 An25.

3 X-ray pattern indicates quartz, plagioclase, and, probably, potassium feldspar present.

Stained thin section indicates that spherulites are potassium feldspar.

X-ray pattern indicates quartz and plagioclase present, potassium feldspar probably absent.

- Stained thin section indicates that potassium feldspar is absent.

7 Spherulitic.

8 Micrographic and spherulitic. 
of quartz and plagioclase, and, in addition, some specimens contain potassium-feldspar. The spherulitic and granophyric matrices contain potassium-feldspar, although the rocks do not necessarily contain potassium-feldspar phenocrysts. On the other hand, rocks containing potassium-feldspar phenocrysts do not always contain the spherulitic or granophyric matrix. The $\beta$ refractive index of plagioclase in the matrix, compared with that of quartz and balsam, indicates that its anorthite content is about that of the plagioclase phenocrysts, $\mathbf{A n}_{25}$.

As in the Attean Quartz Monzonite, the amount of alteration of the quartz porphyry differs greatly from place to place. Plagioclase commonly is partly altered to white mica and clinozoisite-epidote. Aggregates of chlorite, clinozoisite-epidote group, biotite, and ilmenite-sphene intergrowth are all that remain of the mafic minerals in most samples. Relict grains of orange-brown hornblende were observed in one thin section, and possible relict grains of orange-brown biotite, in several sections. Granulation and pronounced undulatory extinction in quartz are attributed to cataclasis accompanying the alteration of the other minerals.

The quartz porphyry body on Sally Mountain (SE-0.49, 5.60) is texturally distinct from that in the dikes, but it is modally similar. The rock consists of quartz and feldspar phenocrysts in a very fine grained matrix. The feldspar is almost completely altered to muscovite, montmorillonite, and calcite; because cataclastic zones are abundant in that area, the rock can easily be mistaken for a highly altered cataclastic rock.

\section{MAFIC DIKES}

Mafic dikes, commonly several feet thick, intrude all the pre-Upper Silurian rocks in the Attean quadrangle. The locations of observed dikes are shown on plate 1 . The best outcrops of these dikes are on the twin summits of an unnamed mountain north of No. 5 Mountain (SC-1.2, 1.5; 1.2, 1.9). On the north summit a mafic dike can be traced for several hundred feet; its thickness ranges from 2 to 10 feet along strike, and its attitude changes somewhat, but it is essentially tabular with smooth contacts. This dike both crosscuts small aplite dikes and is in turn crosscut by other small aplite dikes. A more complex group of dikes is found on the south summit; these dikes split around septa of quartz monzonite, have irregular contacts, and contain inclusions of quartz monzonite. On No. 5 Mountain (SC-1.36, 0.02), a mafic dike cuts a quartz porphyry mass, and the mafic dike is in turn cut by aplite dikes. Quartz porphyry dikes, the mafic dikes, and the 
aplite dikes are all probably closely related to the Attean Quartz Monzonite because of their intimate and reciprocal crosscutting relationships and because of the assumed generic correlation between the Attean Quartz Monzonite and the aplite described above.

The mafic dikes are very fine grained and dark gray; laths of hornblende can be seen without a hand lens in only a few dikes. The rock is characterized by its brown-weathered surface, and it now consists of aggregates of hornblende, chlorite, clinozoisite-epidote, plagioclase, quartz, white mica, and ilmenite-sphene. Judging from the character of the aggregates and the relict textures, the rock seems to have consisted originally of interlocking hornblende and plagioclase laths, 0.1-2.0 $\mathrm{mm}$ in length, having a diabaselike texture. Plagioclase probably formed 35-50 percent of the rock, and hornblende, 65-50 percent. The amount of clinozoisite in the plagioclase aggregates suggests that the original plagioclase was very calcic.

\section{AGE AND CORRELATION}

The age of the pre-Upper Silurian units of the Attean quadrangle cannot be fixed with certainty. These rocks are overlain unconformably by fossiliferous Upper Silurian (lower Ludlow) and Lower Devonian units in the Spencer Lake (Boucot, 1961) and Attean quadrangles. The pre-Upper Silurian units probably can be more specifically assigned, however, to pre-early Late Silurian age (pre-late Llandovery) on the basis of evidence farther south, where rocks of Llandovery Age occur on Limestone Hill in the Stratton quadrangle (fig. 2, D-5) (Boucot, oral commun., 1961). This occurrence is about 6 miles southeast of the southward extension of the pre-Upper Silurian rocks of the Attean quadrangle.

Boucot $(1961$, p. 185) suggested a Precambrian age for the preUpper Silurian rocks; he based this age on the apparent higher grade of metamorphism in rocks in the Spencer Lake quadrangle, which have been traced north to the Attean quadrangle, as compared with units of probable Cambrian and Ordovician age on the east side of the Moose River synclinorium. His observations were made in the area south of Jim Pond in the southwest corner of the Spencer Lake quadrangle where the Silurian and Devonian rocks are absent because of the northeast plunge of the synclinorium, but conclusive relationships have not been worked out in this critical area.

Albee (1961) concluded that all the pre-Upper Silurian rocks are of Cambrian or Ordovician age, or both. His assignment was based on his observation that these rocks are unlike the rocks of known Precambrian age in central Vermont, and on the reconnaissance map- 
ping, which suggested that these pre-Upper Silurian rocks correlate with probable Ordovician rocks in northern New Hampshire.

The divergent views on the age and correlation cannot be rectified until work in progress by the U.S. Geological Survey and the Maine Geological Survey has elucidated the relationships. It is not impossible that the pre-Upper Silurian rocks are divisible into both Precambrian and Cambrian or Ordovician units. The interpretation of Albee (1961) is retained herein, however, and the tentative assignment of the pre-Upper Silurian rocks to the Cambrian or Ordovician, or both, is used throughout the report.

The Attean Quartz Monzonite seems to correlate with the Highlandcroft Plutonic Series of northern New Hampshire (Billings, 1956 , p. 46). Many rocks of that series, as at Highlandcroft Farm itself, are similar to the Attean Quartz Monzonite, and the series is also unconformably overlain by Silurian rocks.

The Highlandcroft Plutonic Series cuts the Albee Formation and the overlying Ammonoosuc Volcanics in New Hampshire; both formations are considered Ordovician (Billings, 1956, p. 94-99, 106). The granofels unit is rather similar to rocks that overlie the Albee Formation in northern New Hampshire, which are assigned to the Ordovician. These rocks could reasonably be correlated with parts of the granofels unit on the basis of position with respect to the regional structural trend. Reconnaissance mapping, though incomplete due to the lack of roads in the northern part of the Cupsuptic and Kennebago quadrangles, suggests this is a reasonable correlation; more recent mapping by John Green (written commun., 1960, 1961, 1962) seems to confirm the results of our reconnaissance. The granofels unit is therefore tentatively assigned to the Ordovician and is interpreted to be younger than the Albee Formation; on this basis the unit may correlate in part with the Ammonoosuc Volcanics but may, in part, be younger.

\section{UPPER SILURIAN ROCKS}

Upper Silurian and Lower Devonian rocks occur as discontinuous lenses between the pre-Upper Silurian rocks and the Seboomook Formation (Lower Devonian), which crops out over much of the northern part of the Attean quadrangle. Locally these rocks are absent, and the Seboomook Formation rests directly upon the pre-Upper Silurian rocks.

Upper Silurian rocks include a limestone and slate unit, which consists mainly of argillaceous limestone and calcareous mudstone; a 
conglomerate unit; and several isolated limestone lenses which are probably equivalent to the limestone and slate unit and have been mapped with it. Both the limestone and slate unit and the conglomerate unit contain Late Silurian fossils, but the fossils are not diagnostic of relative age; the geologic relations are uncertain because the two outcrop areas are separated by an area of thick till and by several ponds.

\section{LIMESTONE AND SLATE UNIT}

Upper Silurian rocks that crop out in the vicinity of Foxs Camp on the north shore of Little Big Wood Pond have been mapped as an unnamed limestone and slate unit. These rocks were named the Fox Limestone by Boucot (1953) but were subsequently (Boucot, 1961, p. 181) assigned to the Hardwood Mountain Formation. No formal name is assigned to this unit because it consists of an isolated patch of Upper Silurian rocks which cannot be traced into other Upper Silurian units. An exact correlation with Boucot's Hardwood Mountain Formation cannot be made; this correlation problem is discussed later.

The limestone and slate unit crops out along the contact with the pre-Upper Silurian rocks in a rather narrow band which extends for about 5 miles northwest from Foxs Camp. A thin layer of limestone on the west border of the quadrangle has been assigned to this unit, although it has not been dated.

The limestone and slate unit includes two main rock types-limestone and calcareous slate and shale. Most of the limestone is very fine grained and contains less than 5 percent detrital material; it is rather dark gray but weathers light gray. Such rock is rather massive, but limestone that contains larger amounts of detrital material is somewhat fissile. The range in composition from limestone to calcareous shale or slate is shown on table 6. Many limestone layers, particularly those near the base of the unit, contain as much as 5-10 percent quartz and feldspar fragments, $2-25 \mathrm{~mm}$ in diameter, and a higher proportion of finer clastic grains. Adjacent layers are commonly calcareous conglomeratic sandstone. Several types of limestone composed almost entirely of organically derived material were also foundphycolitic (algal) limestone at fossil locality BA-236c, coralline limestone at locality BA-1113a, and stromatoporoidal limestone at locality BA-1002 and other localities. (See pl. 2.) Limestone conglomerate consisting of limestone fragments in a calcareous mudstone matrix is characteristic of the Upper Silurian units in northern Maine (Boucot, 1961), but this rock type was observed only at locality BA$230 \mathrm{a}$ in the limestone and slate unit. 
TABLE 6.-Estimated modes and medial grain sizes of calcareous rocks of the limestone and slate unit, Attean quadrangle, Maine

\begin{tabular}{|c|c|c|c|c|c|c|}
\hline \multirow[b]{2}{*}{$\begin{array}{l}\text { Sample } \\
\text { Field No } \\
\text { Location } 1 . \ldots\end{array}$} & \multicolumn{2}{|c|}{$\begin{array}{l}\text { Gray fine-grained } \\
\text { limestone }\end{array}$} & \multicolumn{2}{|c|}{ Gray silty limestone } & \multicolumn{2}{|c|}{$\begin{array}{l}\text { Gray calcareous } \\
\text { shale or slate }\end{array}$} \\
\hline & $\begin{array}{c}1 \\
\mathrm{BA}-1106 \mathrm{E} \\
\mathrm{C}-2.70,4.20\end{array}$ & $\begin{array}{c}2 \\
\text { BA-1107C } \\
\text { NC-0.80,0.77 }\end{array}$ & $\begin{array}{c}3 \\
\mathrm{BA}-1106 \mathrm{H} \\
\mathrm{C}-2.65,4.30\end{array}$ & $\underset{\mathrm{C}-2.64,4.35}{\mathrm{BA}-1106 \mathrm{~K}}$ & $\begin{array}{c}5 \\
\text { BA-114 } \\
\text { C-2.68,4.35 }\end{array}$ & $\begin{array}{c}6 \\
\text { BA-1106L } \\
\text { C-2.64,4.36 }\end{array}$ \\
\hline
\end{tabular}

Estimated modes, in volume percent

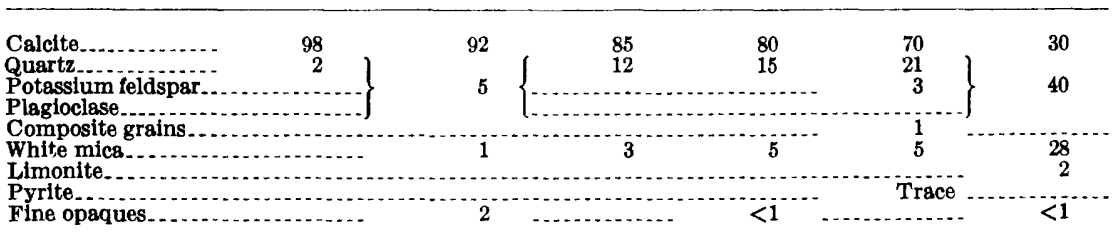

Estimated medial grain sizes, in millimeters; all sizes (except maxima) approximate

\begin{tabular}{lrrrrrr}
\hline Calcite......... & 0.01 & 0.01 & 0.03 & 0.04 & 0.05 & 0.03 \\
Detrital grains..... & .02 & .03 & .04 & 2.04 & 341 & .03 \\
\hline
\end{tabular}

1 Explanation given in description of fieldwork.

2 Maximum 0.5 .

10 percent quartz and 5 percent white mlca also have grain size $\sim 0.05 \mathrm{~mm}$.

- Maximum 3.

The area underlain by the limestone and slate unit is one of dense undergrowth in swamps and in cutover tracts. The topography over the unit is poorly portrayed on the Attean topographic map. In order to understand the stratigraphy, the facies relations, and the nature of the upper and lower contacts, a larger scale, more detailed map was prepared. (See pl. 2.) This larger scale map is based on pace-andcompass traverses, hand leveling, planetable surveying, and transfer from aerial photographs and from the Attean 15-minute quadrangle sheet. An attempt was made to locate all outcrops near the upper and lower contacts of the limestone and slate unit. The coverage is not as thorough in areas not adjacent to these contacts.

In the southern part of the area in the vicinity of Sugar Berth Pond and the area shown on inset map $B$ (pl. 2), the limestone and slate unit consists almost entirely of limestone and calcareous slate and shale, and it seems to be overlain conformably by noncalcareous slate of the Seboomook Formation. Farther north the limestone and slate unit is overlain by Devonian and Silurian conglomeratic sandstone. In the northwest corner of the area (pl. 2, inset map $A$ ), a similar thick-bedded conglomeratic sandstone grades upward by interlamination into noncalcareous slate of the Seboomook (columnar section, inset map $A, \mathrm{pl} .2$ ). Similar interbedded relations of conglomeratic sandstone and noncalcareous slate (Seboomook Formation) are also clearly exposed on a hill 4,800 feet west-southwest of Gander Pond. Hence, between the areas shown on inset maps $A$ and $B$ (pl. 2), a conglom- 
eratic sandstone unit intervenes, in an interfingering relationship, between the limestone and slate unit below and the Seboomook Formation above.

Boucot $(1962$, p. 156 ; oral commun., 1961) has cited the general absence of upper Ludlow and lower Gedinnian units throughout the region as suggestive of a general emergence during that period. In several places, upper Gedinnian (New Scotland-age) units rest unconformably upon lower Ludlow units. If such an emergence did occur, there must be an unconformity in the Foxs Camp-Wood Stream area, either within the slate mapped as Seboomook Formation or within the conglomeratic sandstone unit. Neither possibility can be ruled out, but the truncation of metasedimentary units shown by the geometrical relationships of the bedding on a northwest-trending line between Sugar Berth Pond and the principal access road (pl. 2) suggests that the unconformity either is contained within the Seboomook or is at its base. The areal extent of the unconformity is problematic, and a zone of unconformity could pass into one of conformity within a short reach contained in the Attean quadrangle. All the Upper Silurian and Lower Devonian units that crop out discontinuously between the pre-Upper Silurian rocks and the Seboomook Formation are much alike in that they all contain coarse detritus from the pre-Upper Silurian rocks. Moreover, one of these, the Beck Pond Limestone (Boucot and others, 1959) of New Scotland age, interfingers with the Seboomook, which in that area also contains fossils of New Scotland age. Late Silurian fossils have not been found anywhere within the noncalcareous slate of the Seboomook, and it seems unlikely that this lithology extends downward into the Upper Silurian.

The configuration of the contact between the Attean Quartz Monzonite and the limestone and slate unit near Sugar Berth Pond is partly due to original relief on the older rock surface and partly due to folding. Near Sugar Berth Pond the effect of original relief predominates, but the effects of folding predominate in the area of inset map $B(\mathrm{pl} .2)$ as indicated by the north-northeast-trending synclinal axis.

The idea of original relief is supported by evidence in the sedimentary rocks. The evidence indicates that the Attean Quartz Monzonite was regionally exposed throughout the time that the limestone and slate unit, the conglomeratic sandstone unit, and the lower part of the Seboomook were being deposited. Perthite, plagioclase, compositegrain, and biotite clasts in the sandstones were almost certainly derived locally-particularly, for example, a tabular perthite pebble $25 \mathrm{~mm}$ long. Pebbles and cobbles of Attean Quart Monzonite were 
found at the base of the Seboomook near Foxs Camp, and cobbles and boulders of Attean Quartz Monzonite were found in the Seboomook in the large outcrop 1,200 feet north-northwest of inset map $B$. Nearby, an apparent outcrop of Attean Quartz Monzonite about 10 feet wide, may be a boulder, but it could be a pinnacle of the Attean Quartz Monzonite. The interfingering relationship of the conglomeratic sandstone and Seboomook slate are also suggestive of local relief during the time of deposition. Further evidence for local surface relief on the Attean Quartz Monzonite during Late Silurian time is described in more detail in the section on the conglomerate unit (p. 42).

Few data are available in the swampy lowland south of the main access road and west-northwest of Gander Pond (pls. 1, 2). North of the access road, the Seboomook slate rests with apparent conformity upon the conglomeratic sandstone, and the section faces north according to bedding-cleavage relations. South of the swamp the section also faces north according to the criteria of graded bedding and bedding-cleavage relations; here, however, conglomeratic sandstone rests (geometrically, if not stratigraphically) upon noncalcareous slate of the Seboomook. Limestone along the brook north of the access road is strongly plicated but maintains a regional attitude that is horizontal to gently northward dipping. We have inferred a combination of folds and faults in the area of this swamp to account for the geometric restrictions described above and also for restrictions imposed by the mapped distribution of float in covered areas. We believe that this reconstruction (section, pl. 2) explains the dislocations of stratigraphic units and the rather high erodibility of the ground which produced the swampy lowland. This area is thus indicated to be one of local structural complexity. This complex structure in the metasedimentary rocks is probably a modified extension of the structural feature that produce the cataclastic zone in the Attean Quartz Monzonite. In this sense, the metasedimentary rocks are draped upon the quartz monzonite. Contrasting mechanical properties of the two lithologies probably account for their different deformation habit. The tectonic event that produced the major structural feature is therefore implied to have been active after Early Devonian time.

Fossil collections were made at several localities (pl. 2) within the limestone and slate unit; they indicate a Late Silurian age. A. J. Boucot (written commun., 1959) stated that two distinct faunal facies seem to be present in the fossil collections examined by him. The first faunal facies, characterized by the presence of Leperditia, Protathyris, corals, and stromatoporoids, occurs in limestone; the second faunal facies, characterized by the presence of Isorthis and Eccentricosta jerseyensis, occurs in calcareous mudstone and argillaceous lime- 
stone. These two facies are interbedded. A list of fossils reported from the limestone and slate unit follows.

\section{Fossils reported from localities within the limestone and slate unit}

[Identification are as follows: Brachtopods by A. J. Boucot, "worm tube" by R. B. Neuman, gastropods by E. L. Yochelson, trilobites by A. R. Palmer, and ostracodes and corals by J. M. Berdan. For map locations see plates 1 and 2. USGS numbers are U.S. Geological Survey Silurian-Devonian fossil locality designations]

Locality BA-117 (USGS 4834-SD) : 0.88 mile N. $73^{\circ}$ W. of Foxs Camp, at about 1,400 feet altitude on north side of trail.

Fossils :

Brachiopods :

Indeterminate camarotoechiid

Unidentifled rhynchonellid

Age : Silurian or Devonian

Locality BA-184 (USGS 4835-SD) : 0.35 mile northwest of Foxs Camp, on east shore of Sugar Berth Pond.

Fossils :

Cephalopod fragments

Pelecypod, indeterminate

Gastropods, indeterminate

Brachiopods, indeterminate

Coral :

Favosites sp.

Ostracodes :

Pintopsis sp. cf. P. tricornis (Ulrich and Bassler)

Aitilia? sp.

Limbinaria? sp.

Age : Late Silurian

Locality BA-186a (USGS 4836-SD) : Float, vicinity of Foxs Camp.

Fossils :

Corals :

Favosites sp.

Syringopora sp.

Age : Silurian or Devonian

Locality BA-227 (USGS 4837-SD) : 3.8 miles northwest of Foxs Camp.

Fossils :

Crinoid columnals and other fossil debris.

Age: Post-Cambrian Paleozoic

Locality BA-230a (USGS 4838-SD) : 3.4 miles northwest of Foxs Camp.

Fossils :

Coral :

Favosites? sp.

Stromatoporoid growing over syringoporoid coral.

Age : Silurian to Devonian

Locality BA-236a (USGS 4839-SD) : 0.7 mile northwest of Foxs Camp.

Fossils :

Ostracodes :

Pintopsis sp. cf. P. tricornis (Ulrich and Bassler)

Kloedenella sp.

Age : Late Silurian 
Locality BA-236b (USGS 4840-SD) : 0.7 mile northwest of Foxs Camp.

Fossils:

Coral :

Favosites sp., badly deformed

Age : Ordovician to Devonian

Locality BA-236c (No USGS number assigned, collection discarded) : 0.7 mile northwest of Foxs Camp.

Fossils :

Phycolites

Age: Undetermined

Locality BA-236d (USGS 4841-SD) : 0.7 mile northwest of Foxs Camp.

Fossils :

Ostracodes :

Pintopsis sp. cf. P. tricornis (Ulrich and Bassier)

Zygobeyrichia sp.

Amphitoxotidine beyrichiacean

Leiocyamus sp.

Eukloedenella sp.

Mirochilina sp.

Acanthoscapha sp.

Brachiopods :

Eccentricosta cf. E. jerseyensis (Weller)

Camarotoechia? sp.

Howellella sp.

Protathyris sp.

Worm tube :

Cornulites sp.

Pelecypods :

Two unidentified species

Gastropods :

Clathrospira? new species

Low-spired gastropod, indeterminate

cf. Platyostoma sp.

cf. Loxonema sp.

Trilobite :

Proetus (Proetus) sp.

Age : Late Silurian

Locality BA-236e (USGS 4842-SD) : 0.7 mile northwest of Foxs Camp.

Fossils :

Ostracodes :

Leperditia (Leperditia) sp.

"Kloedenia" sp.

Eukloedenella? sp.

Retisacoulus sp.

Brachiopod :

Protathyris sp.

Age: Late Silurian

Locality BA-236f (USGS 4843-SD) : 0.7 mile northwest of Foxs Camp.

Fossils :

Gastropods :

Platyceratid cf. Platyceras (Visitator) sp.

Indeterminate platyceratid, possibly more than one genus present. 
Locality BA-236f-Continued

Fossils-Conitinued

Trilobite :

Indeterminate thoracic segments

Brachiopods :

Orthostrophia cf. O. brownsportensis Amsden

Coelospira concava (Hall)

Lissatrypa? sp.

Age : Late Silurian

Locality BA-236g (USGS 4844-SD) : 0.7 mile northwest of Foxs Camp.

Fossils :

Brachiopods :

Isorthis sp.

Sphaerirhynchia sp. 1

Camarotoechia? sp.

Coelospira concava (Hall)

Age : Late Silurian

Locality BA-236h (USGS 5583-SD) : 0.7 mile northwest of Foxs Camp.

Fossils :

Brachiopods :

Isorthis sp.

Sphaerirhynchia sp. 1.

Coelospira concava (Hall)

Eccentricosta jerseyensis (Weller)

Camarotoechia? sp.

Howellella sp.

Age : Late Silurian

Locality BA-236i (USGS 5584-SD) : 0.7 mile northwest of Foxs Camp.

Fossils :

Brachiopod :

Protathyris sp.

Age : Late Silurian

Locality BA-237 (USGS 4845-SD) : 0.3 mile northwest of Foxs Camp.

Fossils :

Corals :

Tryplasma sp.

Favosites sp.

Cladopora sp.

Auloporoid coral

Age : Silurian to Devonian, almost certainly former

Locality BA-896b (USGS 4848-SD) : 7,500 feet northwest of Foxs Camp.

Fossils :

Ostracode :

Leperditia sp., large and badly formed

Age: Silurian or Devonian, probably former

Locality BA-999 (USGS 5586-SD) : 8,000 feet northwest of Foxs Camp.

Fossils :

Brachiopods :

Isorthis sp.

Eccentricosta jerseyensis (Weller)

Sphaerirhynchia sp. 1 
Locality BA-999-Continued

Fossils-Continued

Brachiopods-Continued

Coelospira concava (Hall)

Atrypa "reticularis" (Linné)

Age : Iate Silurian

Locality BA-1002 (USGS 5588-SD) : 3.1 miles northwest of Foxs Camp.

Fossils :

Stromatoporoids :

Undetermined

Locality BA-1113a (USGS 5589-SD) : 0.9 mile west-northwest of Foxs Camp.

Fossils :

Corals :

Undetermined

Locality BA-1113b (USGS 5589-SD) : 0.9 mile west-northwest of Foxs Camp.

Fossils :

Corals and gastropods :

Undetermined

Locality BA-1122 (USGS 5590 -SD) : 8,000 feet northwest of Foxs Camp.

Fossils :

Ostracode :

Leperditia

Age : Silurian and Devonian

Locality USGS 2822-SD : 0.4 mile southwest of Foxs Camp, collected by A. J.

Boucot.

Fossils :

Brachiopod :

Protathyris sp.

Ostracodes :

Dizygopleura ef. D. costata Ulrich and Bassler

"Kloedenia" sp.

Leperditia sp.

Limbinaria ef. L. muricata (Ulrich and Bassler)

Velibeyrichia? sp.

Age : Late Silurian

Fossil evidence (Berdan, written commun., 1958; Boucot, written commun., 1959) does not provide an exact correlation of the limestone and slate unit with either the Hardwood Mountain Formation or the overlying lower conglomerate member of the Hobbstown Formation in the Spencer Lake quadrangle to the south (Boucot, 1961, p. 174-176, 180-183), although a locality containing fossils of New Scotland age (Boucot, oral commun., 1958) is now known in the upper part of the Hobbstown Formation (not the type area) southwest of Camera Hill, Spencer Lake quadrangle. All three units are Late Silurian in age, however, and the limestone and slate unit may possibly correlate with the Hardwood Mountain Formation. In addition, the conglomeratic sandstone unit may correlate with the lower conglomerate member of 
the Hobbstown Formation. These correlations are based on lithologic similarities.

\section{GONGLOMERATE UNIT}

Upper Silurian conglomerate that crops out along the eastern summit ridge and north slope of Sally Mountain unconformably overlies the Attean Quartz Monzonite and is overlain by the Seboomook Formation. Its lateral relationship with the limestone and slate unit to the northwest is concealed by till and lakes. We tentatively conclude, however, that these two units are essentially time equivalent and therefore have interfingering relationships. (See pl. 1.) The eastern extension of the conglomerate unit is broken by the intrusive mass of the Hog Island Granodiorite and is concealed farther east by till deposits. A single exposure of similar conglomerate occurs several miles to the east in the Long Pond quadrangle (Long Pond, C-0.25, 1.05), but farther to the south in roadcuts along U.S. Route 201 (Long Pond, SC-1.10, 5.00), fossiliferous slate of the Seboomook Formation seems to directly overlie the Attean Quartz Monzonite. The actual contact is not exposed, but if conglomerate were present it would be expected to crop out as boldly as it does elsewhere.

The conglomerate unit is well exposed in cliffs and smoothly glaciated large outcrops along the summit ridge of Sally Mountain. These outcrops may be reached by the fire-tower trail shown on the map (pl. 1); the trail is still maintained, though the fire tower has been removed.

The conglomerate unit is predominantly a boulder and cobble conglomerate, but it also contains quartzofeldspathic sandstone (quartzite) and conglomeratic sandstone beds. The matrix is light tan to white, but many of the fragments are red, green, or brown. The rock is massive, nonfoliated, and highly indurated and forms smooth rounded outcrops. Bedding can be seen only rarely, either in sorting or in alinement of pebbles, or by the presence of sandy layers in the conglomerate.

The quartzite and the matrix of the conglomerate everywhere consist mainly of quartz and feldspar sand grains in about equal proportions, but as much as 10 percent calcite cement is common in the eastern part of the outcrop area. The potassium feldspar is a microperthite like that in the Attean Quartz Monzonite, and tabular fragments as much as one inch long, still preserving the carlsbad twinning, are abundant. Quartz has undulatory extinction like that in the Attean Quartz Monzonite, and plagioclase is commonly less abundant than the potassium feldspar and more altered, corresponding to the amount of alteration in the Attean Quartz Monzonite. In some thin sections, the feldspar is completely altered to white mica, although the granular 
habit is preserved. Detrital biotite, chlorite, and hornblende are virtually absent in the southwest part of the outcrop area, but are more abundant in the eastern and northern part. The rock is commonly very coherent, and fractures cut through the cobbles; but in the eastern part of the outcrop area, where calcite cemcnt is more abundant, fractures may break around cobbles.

The fragments include porphyitis quart\% monzonite, individual crystals of potassium feldspar, quartz porphyry containing dipyramidal quartz phenocrysts, aplitic quartz monzonite-all from rocks found in the immediately underlying Attean Quartz Monzonite--and medium-grained white sandy limestone. A pronounced lithologic variation exists along the summit ridge of Sally Mountain. To the west, near the site of the fire tower, a very coherent boulder conglomerate that contains fractures which cut through the boulders and cobbles is exposed. Aplite, commonly red, green, or brown due to disseminated iron oxide, is the most abundant fragment type. The matrix is noncalcareous and very similar, compositionally and texturally, to the aplite fragments. The fragments are subrounded, averaging $4-6$ inches in diameter, but a few are 15-18 inches in diameter. To the east the rock commonly contains fractures which cut around fragments. The matrix is commonly calcareous and contains small amounts of biotite, chlorite, and hornblende which make it darker than the matrix in the west. The fragments are generally subangular, and fragments of potassium feldspar, porphyritic quartz monzonite, and limestone are abundant. Numerous angular blocks of sandy limestone are found in cliffs at the north end of the easternmost summit of Sally Mountain. Most blocks are less than 6 inches in greatest dimension, but one is 4 feet wide. The easternmost end of Sally Mountain is within the contact metamorphic zone of the Hog Island Granodiorite, and, although not greatly changed in appearance, some of the conglomerate unit in that area contains garnet, diopside, and hornblende. These contactzone rocks are described in more detail in a later section.

The contact between the conglomerate unit and the underlying Attean Quartz Monzonite is well exposed in the cliffs on the south side of the Sally Mountain ridge. Along most of the ridge the lowest part of the conglomerate unit is a sandstone or quartzite, and large fragments are not abundant. Whether this relationship is consistent throughout the entire unit is unknown. Because the minerals of the quartzite are derived from the underlying rock, the contact is locally quite difficult to locate especially where this quartzofeldspathic sand. stone (the quartzite) rests directly on aplite, and also where conglom. eratic sandstone containing tabular fragments of potassium feldspar rests directly on porphyritic quartz monzonite. The most useful field $438-197-72--4$ 
criterion for locating the contact is that the sedimentary rock contains less ferromagnesian minerals than the Attean Quartz Monzonite.

At the east end of Sally Mountain the minimum thickness of the conglomerate unit is about 1,200 feet. About 500 feet of this thickness is exposed on the south side of the ridge near the site of the fire tower; a continuous exposure in these cliffs is almost entirely conglomerate. The actual thickness of the conglomerate unit is not known because the top of the unit is nowhere preserved or exposed.

Fossils were collected from only one locality in the conglomerate unit; the fauna indicates a Late Silurian age. This locality is just south of Mud Pond (EC-1.30, 1.95), where slightly calcitic quartzofeldspathic quartzite near the base of the unit is exposed in a single small knob. The nearest outcrop, on a knob several hundred feet northeast, consists of boulder conglomerate. Most of the identifiable fossils came from a thin micaceous layer, but a few corals were found in the fine-grained massive quartzite. A list of fossils found at the one locality within the conglomerate unit follows.

\section{Fossils reported from the conglomerate unit}

[Identification are as follows: Brachiopods and gastropod by A. J. Boucot, and corals by J. M. Berdan. USGS number is a U.S. Geological Survey Silurian-Devonian fossil locality designation]

Locality BA-894 (USGS 5995-SD) : Southeast of Mud Pond. Attean quadrangle ( E)C-1.30, $1.95^{1}$ ).

Fossils :

Corals :

Halysites sp.

Syringoporoid coral

Horn corals, indeterminate

Brachiopods :

Coelospira cf. C. saffordi (Foerste)

Eccentricosta cf. E. jerseyensis (Weller)

Leptostrophia sp.

Dolerorthis? cf. D. hami (Amsden)

Amphistrophia funiculata (McCoy)

Atrypa arctostriata Foerste

Dalejina sp. 1.

Gastropod :

"Euomphalopterus" gasconensis Northrop

Age: Late Silurian

1 Explanation given in description of fieldwork.

As stated before, the conglomerate unit cannot be traced directly into the limestone and slate unit, and no exact correlation can be made on the basis of faunal similarities (Boucot, written commun., 1959). Boucot stated, however, that this collection can best be correlated with the fauna of the lower conglomerate member of the Hobbstown Formation in the Spencer Lake quadrangle (Boucot, 1961, 
p. 174) and with the Isorthis-Eccentricosta jerseyensis faunal facies of the limestone and slate unit (Boucot, written comm., 1959). Both the sequence of rock types and the faunal evidence also allow tentative correlation of the conglomerate unit with the lower part of the conglomeratic sandstone unit and with the lower conglomerate member of the Hobbstown Formation. If this correlation is correct, the rock sequence also suggests that the limestone and slate unit and the Hardwood Mountain Formation of the Spencer Lake quadrangle are absent in the Sally Mountain area.

The fossils were found in the quartzite that is near the base of the conglomerate unit; thus, the higher parts of the unit, or even all of the conglomerate, could be of Early Devonian age. Such an age distinction seems unrealistic, however, because the quartziteconglomerate contact exposed on Sally Mountain ridge is strictly conformable without apparent sedimentological break. Also, quartzite and conglomerate probably interfinger within the unit to a greater degree than we have observed.

Several hundred feet of original relief is likely at the base of this unit, as is postulated for the limestone and slate unit. It is difficult to prove this original relief in the absence of abundant planar features within the conglomerate unit and the Attean Quartz Monzonite, but the trace of the contact along the south face of Sally Mountain ridge suggests that as much as several hundred feet of relief was present on the top of the Attean Quartz Monzonite when the conglomerate unit was deposited.

The contact of the conglomerate unit and the overlying Seboomook Formation is not exposed.

\section{UPPER SILURIAN AND LOWER DEVONIAN ROCKS}

A conglomeratic sandstone unit of Late Silurian and Early Devonian age interfingers with the limestone and slate unit (Upper Silurian) below and the Seboomook Formation (Lower Devonian) above.

\section{CONGLOMERATIC SANDSTONE UNIT}

The conglomeratic sandstone unit crops out in a northwest-trending sinuous narrow belt in the north-central part of the quadrangle, between 1.4 and 5 miles northwest of Foxs Camp.

The sandstone occurs in thick beds and is light tan to light brown. It is almost everywhere conglomeratic, but nowhere does it contain enough clasts to be called a conglomerate. The rock consists mainly of quartz, feldspar, white mica, and calcite, but calcite cement is absent in much of the rock. Estimated modes of typical samples are given in table 7. The feldspar consists of perthite, plagioclase, and 
composite grains-all clearly derived from the underlying quartz monzonite. The texture is granular interstitial; silica and calcite cement are present in some samples. The dominant grain size is about $0.5-1.5$ $\mathrm{mm}$; the interstitial grain size, about $0.05 \mathrm{~mm}$; and the maximum grain size, $3-25 \mathrm{~mm}$. Most of the grains are subangular.

TABLE 7.--Estimated modes and grain sizes of the conglomeratic sandstone unit and Seboomook Formation, Attean quadrangle, Maine

The conglorneratic sandstone unit and the Seboomook Formation rocks described herein are granulebearing coarse-grained sandstones containing different amounts of calcite cement]

\begin{tabular}{|c|c|c|c|c|c|c|}
\hline \multirow[b]{2}{*}{$\begin{array}{l}\text { Sample } \\
\text { Fleld No } \\
\text { Location } 1-\end{array}$} & \multicolumn{4}{|c|}{ Seboomook Formation } & \multicolumn{2}{|c|}{$\begin{array}{l}\text { Conglomeratic } \\
\text { sandstone unit }\end{array}$} \\
\hline & $\begin{array}{c}1 \\
\text { BA-1107M } \\
\text { NC-0.85, } \\
0.93\end{array}$ & $\begin{array}{c}2 \\
\mathrm{BA}-1107 \mathrm{~J} \\
\mathrm{NC}-0.83 \\
0.85\end{array}$ & $\begin{array}{c}3 \\
\text { BA-1107N } \\
\text { NC-0.85, } \\
0.95\end{array}$ & $\begin{array}{c}4 \\
\text { BA-339 } \\
\text { C-2.15 } \\
5.40\end{array}$ & $\begin{array}{c}5 \\
\text { BA-185a } \\
\text { C-2.80, } \\
4.22\end{array}$ & $\begin{array}{c}6 \\
\text { BA-996 } \\
\text { C-2.32, } \\
5.01\end{array}$ \\
\hline
\end{tabular}

Modes, in volume percent

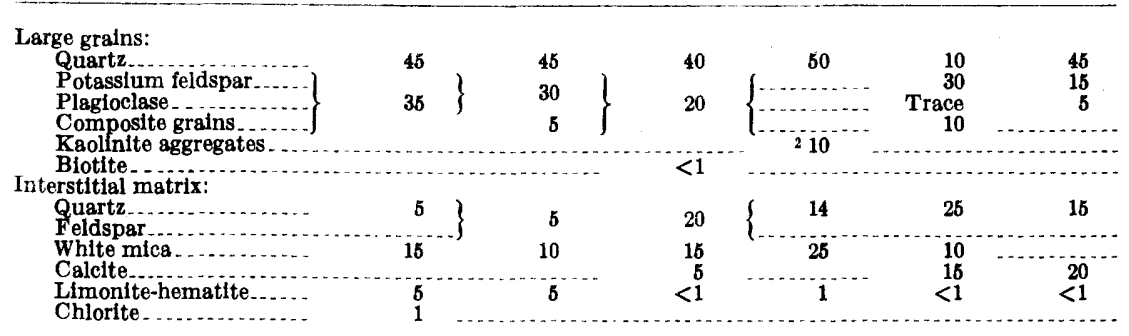

Grain sizes, in millimeters

\begin{tabular}{|c|c|c|c|c|c|c|}
\hline $\begin{array}{l}\text { Large grains: } \\
\text { Medial_.............. } \\
\text { Maximum }\end{array}$ & $\underset{3}{\sim 0.5}$ & $\sim 0.6$ & $\underset{3}{\sim 0.8}$ & $\begin{array}{r}\sim 0.6 \\
2.5\end{array}$ & 10 & $\underset{2}{\sim 0.5}$ \\
\hline Interstitial matrix: & & & & & & \\
\hline Medial & . & $\sim .05$ & .03 & .05 & .2 & .05 \\
\hline
\end{tabular}

1 Explanation given in description of fieldwork.

2 Verified by $\mathrm{X}$-ray analysis.

The unit interfingers with units above and below. The upper and lower contacts of the unit are described in the section on the limestone and slate unit (see p. 35) and are graphically shown on plate 2 (section $A-A^{\prime}$; inset map $A$ ).

The age of the conglomeratic sandstone has been determined by paleontologic and regional stratigraphic evidence (see p. 41). The lower part of the unit may be correlative with the conglomerate unit (see p. 45). Only two fossil localities were found within the unit. At fossil locality BA-1001 (pl. 2) an argillaceous limestone interbed very near the base of the conglomeratic sandstone unit contains fossils of Late Silurian age. Fossil locality RB-74 (pl. 2) is in beds that interfinger with Seboomook noncalcareous slate; the fossils are not, however, diagnostic of the age of the unit. A list of the fossils reported from the conglomeratic sandstone unit follows. 
Fossils reported from localities within the conglomeratic sandstone unit

[Identifications by A. J. Boucot. USGS numbers designate U.S. Geological Survey Silurian. Devonian fossil localities]

Locality BA-1001 (USGS 5587-SD) : 11,500 feet northwest of Foxs Camp.

Fossils :

Brachiopods :

Eccentricosta cf. $E$. jerseyensis (Weller)

Isorthis sp.

Sphaerirhynchia sp. 1

Gypidula sp. 2

Agle : Late Silurian

Locality RB-74: 2.4 miles northwest of Foxs Camp. Calcareous conglomeratic sandstone.

Fossils :

Brachiopods :

Atrypa "reticularis"

Dolerorthid? sp.

Age : Silurian or Devonian

\section{LOWER DEVONIAN ROCKS}

Devonian sedimentary rocks crop out over the northern two-fifths of the Attean quadrangle. These rocks include the Seboomook and Frontenac Formations (both Lower Devonian). The Frontenac in general overlies the Seboomook but in part is probably equivalent to it in age. Both units were deformed and metamorphosed during the Acadian orogeny.

\section{SEBOOMOOK FORMATION}

Perkins (1925, p. 374-375) applied the name Seboomook Slate to interbedded dark-gray sandstone and slate exposed at Seboomook Dam, about 32 miles northeast of Jackman. Boucot (1961) mapped the extension of this unit into the Attean quadrangle, but used the term Seboomook Formation because sandstone constitutes a large part of the unit in many places, including the area near Seboomook Dam. At the type locality-along the river, upstream and downstream from the dam-the formation has a pronounced cyclic layering, 1.5 to 2 inches thick; each layer grades from a fine-grained argillaceous metasandstone upward into slaty mudstone.

In the Attean quadrangle the Seboomook Formation crops out in an east-northeast-striking band; the band is about 2 miles wide at the west edge of the quadrangle, where the section is virtually unrepeated. but it is about 7.5 miles wide at the east edge, mainly due to repetition by folding or faulting, or both. 
The area underlain by the Seboomook Formation has a moderate relief and is characterized by north-northeast-trending major ridges and stream valleys. Surficial deposits are thick on the lower slopes and in the valleys, and such areas commonly are overgrown by a dense coniferous forest. The ridges usually have a thin till cover, a less dense deciduous forest, and small abundant outcrops. The outcrops occur as small east-northeast-trending ridges, a few feet to a few tens of feet high, crossing the major ridges. The character of the outcrop is such that, in a traverse along the major north-northeast ridges, the lithology can be observed nearly continuously, but the amount of repetition by folding cannot be determined.

The Seboomook Formation consists of gray slate that contains quartzose laminae, 2-10 mm thick; locally the slate appears to grade into a greenish-gray phyllite. Typical accessible exposures of the slate are near Moose River village (EC-3.35, 4.45 and EC-2.45, 5.15) and on the east shore of Crocker Pond (NC-3.6, 1.1). Typical exposures of phyllite are in roadcuts on U.S. Route 201 (NE-1.85, 3.75) and in natural outcrops along a gravel road (NE-2.22,3.45).

The slate is dark gray and weathers light tan. Individual mineral grains are too fine to discern with a hand lens, but grains in the more quartzose layers attain silt or fine-grained sand size. The quartzose laminae commonly contain more iron oxide than the slate, weather light brown, and may be separated by slate layers several feet thick. Graded bedding is common. Cleavage transverse to bedding is the dominant foliation in the rock; in the slate layers it is a close-spaced slaty cleavage, but in the quartzose layers it has a different orientation and is more widely spaced or absent.

The greenish-gray phyllite weathers light greenish tan and generally seems less quartzose and more chloritic than the typical slate. The rock is typically crumpled or plicated, and the transverse cleavage is associated with small crinkles or steplike offsets of the bedding or bedding schistosity. Some degree of silicification is usually present and is manifested macroscopically by small quartz veinlets and lenses. In general, the phyllite is more abundant toward the contact with the Frontenac Formation, but every gradation between the phyllite and the slate can be seen. The phyllite most probably differs from the slate in the character of the internal deformation rather than in the quartz and chlorite content.

The slate has a granular-interstitial texture; however, generally parallel platy minerals in the bedding and cleavage planes wrap around the subangular granular minerals. Nearly every specimen has good graded bedding; the granular minerals grade in size from 0.04 
$0.06 \mathrm{~mm}$ diameter in the more quartzose layers to about $0.01 \mathrm{~mm}$ diameter in the less quartzose layers.

Thirty-nine thin sections of the Seboomook were studied, $1 \dot{b}$ of which were checked by $\mathrm{X}$-ray diffraction analyses because of the fine-grained texture of the slate. About two-thirds of these 39 specimens contain 40-65 percent white mica and chlorite and $30-50$ percent quartz and plagioclase. Some of the remaining specimens contain as much as 80 percent quartz and plagioclase, and others as much as 95 percent white mica and chlorite. Opaque minerals, including graphite, pyrite, magnetite, ilmenite, and limonite, commonly constitute $1-5$ percent of the rock. Less than 1 percent calcite occurs in a few specimens. Trace amounts of zircon, apatite, rutile, and tourmaline are common.

The metamorphic recrystallization of the slate in the Seboomook was extensive. Muscovite and chlorite are rather coarse grained and oriented in a systematic relationship to the slaty cleavage. Potassium feldspar was not observed, and plagioclase feldspar is not abundant. The crystallinity, reflected in the $\mathbf{X}$-ray pattern of the muscovite and chlorite, is unlike that of diagenetic mica and chlorite normally found in sedimentary rocks.

The estimated modes were determined from the $\mathbf{X}$ ray diffraction patterns and were based on comparison with $\mathrm{X}$-ray patterns of samples for which the modes were calculated from chemical analyses (table 8). Modes were calculated for three samples from the Seboomook Formation, one from the Tarratine Formation (Boucot, 1961, p. 165), which is in part a sandy lateral equivalent of the Seboomook, and one from the Tomhegan Formation (Boucot, 1961, p. 161), which overlies the Tarratine.

The plagioclase is untwinned clear albite (only a few twinned grains were observed), which is very difficult to distinguish from quartz in thin section. Correspondence of the X-ray diffraction data and the calculated modes indicates that the thin-section estimates of albite and chlorite content were grossly low and that each generally constitutes about 15 percent of the slate, about half the percentage of white mica.

Examination of thin sections indicates that, though white mica and chlorite are the most abundant platy minerals in the Seboomook, kaolinite and montmorillonite may be present in a few samples. Positive identification was not possible in the $\mathrm{X}$-ray diffraction patterns for the total rock. The finer grained material from six samples was therefore separated by sedimentation and deposited with preferred orientation on a ceramic tile. The tile samples were then $\mathrm{X}$-rayed untreated, after saturation with ethylene glycol, and after heating to 
450-500 ${ }^{\circ} \mathrm{C}$. All samples gave prominent, sharp 14-, 10-, and 7-A $d$-spacing peaks and none of the peaks were shifted after treatment with ethylene glycol; the 7-A peaks were destroyed, and the 14-A peaks were strengthened, by heat treatment. The criteria of Johns,

TABLE 8.-Chemical analyses, calculated modes, and relative proportions of cations in chlorite of slate from the Seboomook Formation and slate and sandstone from related formations, west-central Maine and New Hampshire

[Sample 1 analyzed by M. Balazs; sample 2 analyzed by methods described by Shapiro and Brannock (1956) . samples 3 and 4 analyzed by $\mathrm{H}$. H. Hyman and C. Warshaw; and samples 6 and 7 are from Shaw (1966) Modes were calculated by assigning $\mathrm{Ti}$ to rutile, $\mathrm{Fe}^{+3}$ to magnetite, $\mathrm{C}$ to graphite, $\mathrm{S}$ to pyrite, $\mathrm{P}$ to apatite $\mathrm{CO}_{2}$ to calcium-magnesium carbonate, $\mathrm{Na}$ to albite, and $\mathrm{K}$ to muscovite. The remaining metals $\left(\mathrm{Fe}+\mathrm{Mn}+\mathrm{Mg}=\mathrm{Fm}\right.$, and $\mathrm{Al}$ ) were assigned to chlorite, $\mathrm{Fm}_{0}-{ }_{x} \mathrm{Al}_{2 x} \mathrm{Si}_{4} \rightarrow{ }_{x} \mathrm{O}_{10}(\mathrm{OH})_{R}$, and the remaining Si to quartz]

\begin{tabular}{|c|c|c|c|c|c|c|c|c|}
\hline Sample........... & 1 & 2 & $\mathbf{3}$ & 4 & 5 & & 6 & 7 \\
\hline $\begin{array}{l}\text { Field No.... } \\
\text { Lab Nos.... }\end{array}$ & $\begin{array}{l}\text { IDC-13, } \\
\text { ID-20950 }\end{array}$ & $\underset{156032}{\text { BB2527 }}$ & IDS 153, & $\begin{array}{l}\text { IDC-13, } \\
\text { ID-20850 }\end{array}$ & $\begin{array}{l}\text { IDC-13, } \\
\text { ID }-21050\end{array}$ & $\begin{array}{l}\text { Aver: } \\
\text { age }\end{array}$ & $\begin{array}{l}\text { Standard } \\
\text { deviation }\end{array}$ & $\begin{array}{l}\text { Aver- Standard } \\
\text { age deviation }\end{array}$ \\
\hline
\end{tabular}

Chemical snaiyses, in weight percent

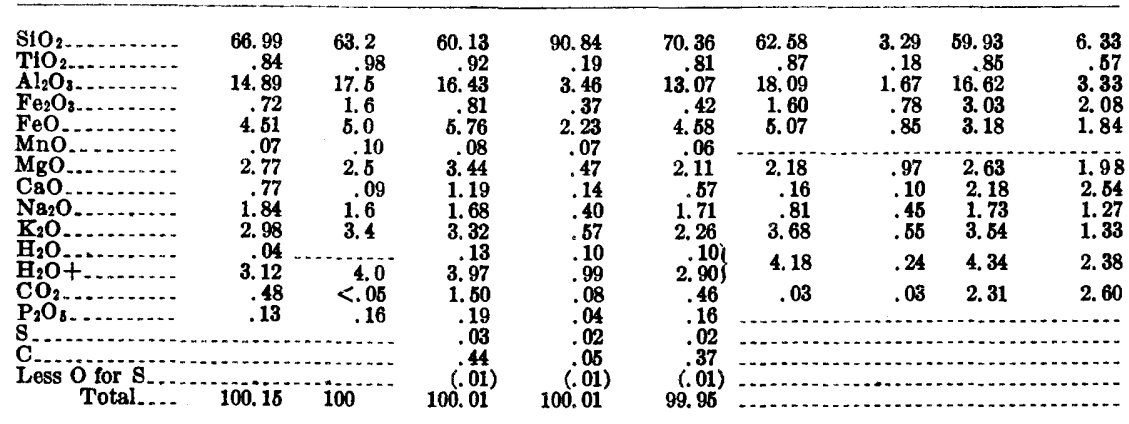

Calculated modes, in cation percent

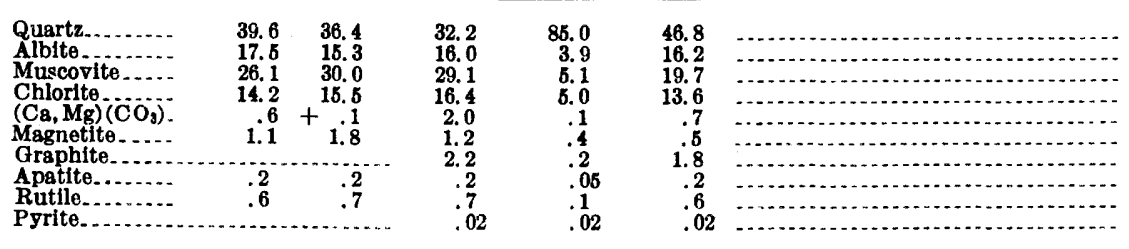

Calculated relative proportions of $\mathrm{Fe}, \mathrm{Mg}$, and $\mathrm{Al}$ in chlorite

\begin{tabular}{|c|c|c|c|c|}
\hline $\begin{array}{c}\mathrm{Fe}_{2.3} \\
\mathrm{Mg}_{2.8} \\
\text { Ali.8 }\end{array}$ & $\begin{array}{r}\mathrm{Fe}_{2.4} \\
\mathrm{Mg}_{2.2} \\
\mathrm{Al}_{2.8}\end{array}$ & $\begin{array}{l}\mathrm{Fe}_{2.3} \\
\mathrm{M}_{2.0} \\
\mathrm{Al}_{2.0}\end{array}$ & $\begin{array}{r}\mathrm{Fes}_{3.5} \\
\mathrm{Mg}_{1.4} \\
\mathbf{A l}_{2.2}\end{array}$ & $\begin{array}{r}\mathrm{Fe}_{2.7} \\
\mathrm{Mg}_{2.1} \\
\mathrm{Al}_{2,4}\end{array}$ \\
\hline
\end{tabular}

1. Cyclic-layered slate, Seboomook Formation: North East Carry quadrangle, WC-0.09, 4.10, roadcut at BM 1136.

2. Slate, Seboomook Formation. Attean quadrangle, EC-3.42, 4.45.

3. Slate, Seboomook Formation. Long Pond quadrangle, C-1.04, 2.81, railroad cut.

4. Sandstone, Tarratine Formation. Long Pond quadrangle, SE-0.2, 3.4, Parlin Gorge.

5. Sandy slate, Tomhegan Formation. Brassua Lake quadrangle, $\mathrm{C}-3.77,2.07$, rallroad cut.

6. Average and standard deviation for seven analyses of slate from the Littleton Formation, New Hampshire (Shaw, 1956, p. 924).

7. Average and standard deviation for 85 single, composite, or averaged analyses of clay, shale, or slate (Shaw, 1956, p. 928). 
Grim, and Bradley (1954, p. 243) indicate that white mica (illite) and chlorite are present in these samples, but that kaolinite and montmorillonite are absent.

The white mica is muscovite that has a fairly low sodium content as indicated by (004) spacings of 4.96-4.99 A. Absence of paragonite is indicated by the lack of a doublet for the muscovite (004) peak.

The composition of chlorite was inferred from optical and X-ray properties using the criteria of Albee (1962) and was also calculated from the chemical analyses of the rocks (table 8 ). Most of the chlorite has an iron to magnesium ratio slightly greater than one, but variations to less than one were noted. This range is typical of chlorites from quartz-mica schists (Albee, 1962). Basal spacings of 14.09, 14.10, $14.13,14.14,14.15$, and $14.15 \mathrm{~A}$ were calculated by averaging the (003), (004), and (005) peaks and using quartz as an internal standard. A basal spacing of $14.14 \mathrm{~A}$ indicates an aluminum content of approximately 2.68 per 10 cations. The chlorite compositions calculated from the chemical analyses have a lower aluminum content than is indicated by the X-ray data and also than is commonly found in quartz-mica schist.

Comparisons of the chemical analyses indicate significant variations in $\mathrm{SiO}_{2}, \mathrm{MgO}, \mathrm{CaO}$, and $\mathrm{CO}_{2}$ content among the samples; the relative proportions of other oxides do not differ as much. These variations are amplified by calculating the modes from the chemical analyses (table 8). Quartz and dolomite-calcite percentages vary significantly, whereas percentages for the other minerals do not.

The Littleton Formation (Lower Devonian) of New Hampshire (Billings, 1956, p. 27-35) is lithologically similar to the Lower Devonian slates of Maine. Averages and standard deviations for seven analyses of low-grade slate from the Littleton Formation (Shaw, 1956, p. 924) are also given in table 8 . Seboomook slate has a distinctly lower $\mathrm{Fe}_{2} \mathrm{O}_{3}$ content and a higher $\mathrm{Na}_{2} \mathrm{O}$ content than the Littleton. The $\mathrm{SiO}_{2}$ content is somewhat higher, and $\mathrm{Al}_{2} \mathrm{O}_{3}$ somewhat lower, in the Seboomook than in the analyzed samples of the Littleton; one sample of the Seboomook contains several percent dolomite or calcite, which is reflected in the $\mathrm{CO}_{2}, \mathrm{CaO}$, and $\mathrm{MgO}$ values. Table 8 also contains the averages and standard deviations for 85 single, composite, or averaged analyses of clay, shale, or slate (Shaw, 1956, p. 928). Although the Seboomook differs somewhat from this average, only the low $\mathrm{Fe}_{2} \mathrm{O}_{3}$ and high $\mathrm{FeO}$ values can be considered at all anomalous. However, the $\mathrm{CaO}$ and $\mathrm{CO}_{2}$ contents are low in comparison with the average.

The Seboomook Formation has a minimum thickness of 5,000 feet in the western part of the Attean quadrangle, where dips of approximately $30^{\circ}$ near the upper and lower contacts are believed to repre- 
sent the minimum dip trend of the unit. We estimate that the actual thickness of the unit here is $6,000-7,000$ feet. Dips greater than $30^{\circ}$ found in the center of the unit are interpreted to be a manifestation of internal folding. The amount of repetition probably increases in magnitude eastward and the average dip of the unit decreases from $30^{\circ}$, thus accounting for the rather wide belt of exposure on the eastern border of the quadrangle. The unit also may thicken eastward across the quadrangle, but the amount of repetition is not known, and we cannot estimate the thickness.

Boucot (1961, p. 170) reported that the type section of the Seboomook Formation contains 10,000 feet of rock and that the whole formation is as much as 20,000 feet thick. The unit extends southwestward through Quebec into New Hampshire and maintains about the same outcrop breadth found on the western side of the quadrangle; no great change in thickness is believed to occur.

The Seboomook Formation of the Attean quadrangle contains Early Devonian, Becraft-Oriskany-age fossils from three outcrop locations and from a boulder (locality BA-1108) ; all are on the eastern side of the Attean quadrangle. The boulder, a distinctive hornfels from the Seboomook Formation, can be restored confidently to its original locality near the lower part of the unit. A list of the fossils recorded from these localities follows.

Fossils reported from localities within the Seboomook Formation

[Identifications by A. J. Boucot. USGS numbers designate U.S. Geological Survey SilurianDevonian fossil localities ]

Isocality BA-210: Island in Wood Pond, Attean quadrangle (EC-2.3, 3.1 ${ }^{1}$ ). Cordierite hornfels containing pebbles of Attean Quartz Monzonite.

Fossils :

Bryozoan?

Locality BA-213: Island in Wood Pond, Attean quadrangle (EC-1.9, 2.7 ${ }^{1}$ ). Cordierite hornfels containing pebbles of Attean Quartz Monzonite.

Fossils :

Bryozoan

Crinoid columnals

Fragmentary brachiopods

Locality BA-1108: 3-foot-thick block found on east shore of Wood Pond. Almost certainly derived from vicinity of $\mathrm{BA}-\mathbf{2 1 0}$ and $\mathrm{BA}-213$. Cordierite hornfels containing pebbles of Attean Quartz Monzonite.

Fossils :

Brachiopods :

Acrospirifer ef. A. murchisoni (Castenau)

Eccentricosta? sp.

Leptocoelia sp.

Tentaculites sp.

${ }^{1}$ Explanation given in description of fieldwork. 
Locality BA-1108-Continued

Age : Early Deronian, probably Oriskany

Locality BB-2527 (USGS 2880-SD), Boucot Collection: Moose River village; Attean quadrangle (EC-3.42, $\left.4.45^{1}\right)$.

Fossils :

Brachiopod :

Leptocoelia flabellites (Conrad), single valve found on bedding plane Age : Oriskany

Locality RB-75: Long Pond quadrangle (SC-1.07, 5.05 ${ }^{1}$ ). Slumped highway cut and not definitely outcrop.

Fossils :

Brachiopod :

Leptocoelia flabellites (Conrad)

Age : Oriskany

${ }^{1}$ Explanation given in description of fieldwork.

Boucot (1961, p. 170; written commun., 1959) stated that the Acrospirifer and Leptocoetia occurrences indicate that the age of the Seboomook Formation here is consistent with the age of much of the unit in the Moose River synclinorium. He has not, however, established the age of the top and bottom of this unit. Pebbles of Attean Quartz Monzonite were found in the fossil-bearing hornfels; this fact suggests that the hornfels is from a stratigraphic position very close to the base of the formation. If this is so, then the base of the unit is of Becraft-Oriskany age in the eastern part of the quadrangle. At Beck Pond in the Spencer Lake quadrangle, however, a fossil assemblage of New Scotland age is found in the lower part of the Seboomook Formation (Boucot and others, 1959; Boucot, 1961, p. 170).

East of the Attean quadrangle the Seboomook Formation grades laterally and upward into the Tarratine Formation of Oriskany age (Boucot, 1961, p. 166). Within the Attean quadrangle the Seboomook is interpreted to grade upward into the undated Frontenac Formation. If this interpretation is correct, then the Frontenac and Tarratine Formations are essentially correlative. The assignment of the Frontenac to Early Ievonian age, however, is an equivocal matter. (See following section).

\section{FRONTENAC FORMATION}

The name "Frontenac" was introduced by McGerrigle (1935) for the volcanic rocks of the Mount Megantic area, Quebec, about 40 miles southwest of Jackman. Volcanic rocks are less abundant than sandstone in the Frontenac northeast of Mount Megantic, and massive argillaceous sandstones predominate to the virtual exclusion of volcanic rocks in the Attean quadrangle. Hence, the name Frontenac Formation is applied here to the massive argillaceous sandstone as well as to the volcanic rocks, following the usage of Marleau (1958a; 1958b, p. 67- 
70). Although McGerrigle (1935, p. 74) believed that the massive argillaceous sandstones were infolded into the volcanic rocks, Marleau (1958b, p. 70-73) has demonstrated that the two rock types are actually interstratified.

The Frontenac Formation crops out in the extreme northern part of the Attean quadrangle and is the southern part of a band of the formation, 8-13 miles wide, which lies in the center of an inferred eastnortheast-trending syncline (fig. 2). The trace of the axial plane of this syncline passes through the extreme northwest corner, the Quebec part, of the Attean quadrangle and is subparallel to the South Branch of the Penobscot River in the Sandy Bay quadrangle.

The Frontenac Formation is composed of a distinctive fine- to medium-grained greenish-gray slightly calcareous, argillaceous metasandstone interbedded with greenish-gray phyllite and slate that resemble those of the Seboomook Formation. Individual beds of the metasandstone range in thickness from several inches to 40 feet, but those 5 to 15 feet thick greatly predominate. The intervening phyllite layers commonly are about the same thickness as the metasandstone beds but also are generally much thinner than adjacent metasandstone layers. Also, some of the rock consists of interlayers, less than an inch thick, of metasandstone and phyllite. The base of the unit is placed at the base of the lowest thick argillaceous metasandstone bed. The thick metasandstone layers and sills of hornblende diorite form the prominent east-northeast-trending ridges, and the phyllite underlies the narrow deep "guts" between the ridges, as a result of the contrasting erodibility of the lithologies.

The metasandstone is rather dark greenish gray on a fresh surface, but weathering forms a light-gray surface rind about $5 \mathrm{~mm}$ thick. Although the metasandstone characteristically appears massive and unfoliated, a poor foliation is formed by parallel orientation of platy minerals. Locally, the more micaceous beds have a rather widely spaced transverse cleavage, commonly 1-10 $\mathrm{mm}$ between cleavage planes, and the foliation is commonly parallel to bedding in thin phyllite interbeds between thick sandstone layers. In general, however, the foliation is a closely spaced transverse cleavage. As in the Seboomook Formation, the phyllite grades into the slate.

Metasandstone and phyllite are exposed along U.S. Route 201 near the southern contact of the Frontenac (NE-1.80, 4.50-4.85) and crop out at the north edge of the Attean quadrangle (NE-1.25, 5.7). More typical sequences can only be seen by traversing the ridges-Sandy Stream and Slidedown Mountains-or the international boundary line.

Several sedimentary or probable sedimentary features are still preserved. Graded bedding is common in the thinner beds, but is rarely 
well formed in the thicker beds. Sandstone in several places (for example, NC-0.80, 3.76) contains small chips of shale or slate which have been streaked out into the plane of the foliation. One such shalechip conglomerate (NE-1.23, 5.70; exposed in an artificial cut made when the brook was moved during construction of the highway) was probably formed by clay-sized particles filling the troughs of ripple marks in sand. These "chips" have also been streaked out during the deformation. Calcitic concreations in sandstone were observed at several localities (for example, NW-1.40, 2.42; NC-1.35, 4.60). Commonly, the sandstone contains both small pellets, $0.5-1$ inch in diameter, and larger elipsoidal masses of calcitic concretions. The largest masses seen in all dimensions were about 2 feet long and about 4 by 8 inches in cross section. The largest mass seen only in cross section measured about 2 by 4 feet. The concretions consist of only about 5 percent calcite cementing the normal sandstone. Quartzose pellets, about $10 \mathrm{~mm}$ in diameter, and lenses, about 5 by $25 \mathrm{~mm}$ in cross section, were also noted on the weathered surfaces at some places. They are almost invisible on a fresh surface and even in thin section and seem to represent merely a high concentration of quartz grains. The texture of the pellets is like that of the matrix, and they are believed to be of sedimentary origin.

The sandstone has a granular-interstitial texture. Subrounded to subangular quartz grains, $0.1-0.3 \mathrm{~mm}$ in diameter, are set in a finer grained matrix $(0.01-0.06 \mathrm{~mm})$ of both granular and platy minerals. The platy minerals are commonly in parallel orientation. Modes were estimated in 26 thin sections of the typical sandstone; the medial 20 values have the following range : $75-85$ percent quartz and feldspar; $10-20$ percent white mica and chlorite ; $0-5$ percent calcite; $0-3$ percent sphene, leucoxene, and rutile; and 0.2 percent ilmenite, magnetite, graphite, and pyrite. The medial 20 of 25 thin-section estimates had a range of 2-20 percent plagioclase and 1-5 percent chlorite, but data from $\mathrm{X}$-ray analyses of the total rock suggest that these figures are low. A few grains of potassium feldspar were observed in several thin sections. Seven estimated modes from selected thin sections are given in table 9 .

Finer grained material from one sample of typical argillaceous sandstone was separated and analyzed by $\mathrm{X}$-ray methods before and after ethylene glycol and heat treatment. The presence of white mica and chlorite was confirmed, but kaolinite and montmorillonite are not present. The white mica is identified as muscovite that has a fairly low sodium content by (004) spacings of 4.93-4.96 A. The lack of a doublet for that peak indicates that paragonite is absent. 
TABLE 9.-Estimated modes and grain sizes and some properties of chlorite from samples of the Frontenac Formation, Attean and Sandy Bay quadrangles, Maine

\begin{tabular}{|c|c|c|c|c|c|c|c|}
\hline $\begin{array}{l}\text { Sample } \\
\text { Field No } \\
\text { Location } 1 . \ldots\end{array}$ & $\begin{array}{c}1 \\
\text { BA-6a } \\
\text { SE-1.2, } 0.1 \\
\text { (Sandy Bay } \\
\text { quadrangle) }\end{array}$ & $\begin{array}{c}2 \\
\mathrm{BA}-156 \\
\mathrm{NC}-2.93 \\
4.55\end{array}$ & $\begin{array}{c}3 \\
\text { BA-165b } \\
\text { NC-3.50, } \\
4.39\end{array}$ & $\begin{array}{c}\stackrel{4}{2} \text { BA-254b } \\
\text { NC-1.59, } \\
5.27\end{array}$ & $\begin{array}{c}5 \\
\text { BA-269a } \\
\text { NC-2.42, } \\
4.50\end{array}$ & $\begin{array}{c}6 \\
B A-74 f \\
\text { NE-2.75, } \\
4.79\end{array}$ & $\begin{array}{c}{ }^{7} \\
\text { BA-126 } \\
\text { SC-4.0, } 0.27 \\
\text { (Sandy Bay } \\
\text { quadrangle) }\end{array}$ \\
\hline
\end{tabular}

Estimated modes, in volume percent

\begin{tabular}{|c|c|c|c|c|c|c|c|}
\hline \multicolumn{8}{|l|}{ Rock fragments.. } \\
\hline $\begin{array}{l}\text { Muscovite }{ }^{2} \\
\text { Biotite. }\end{array}$ & 10 & 12 & $\mathbf{1 3}$ & 13 & 15 & 2 & $\begin{array}{r}10 \\
3\end{array}$ \\
\hline Chlorite...... & 3 & 1 & i & 2 & 5 & 25 & $\mathbf{1}$ \\
\hline Quartz & 10 & 79 & 70 & 75 & 62 & 2 & 55 \\
\hline Plagioclase........ & 65 & 5 & 10 & 5 & 10 & 55 & 25 \\
\hline \multirow{2}{*}{\multicolumn{8}{|c|}{$\begin{array}{l}\text { Potassium } \\
\text { feldspar..... }\end{array}$}} \\
\hline & $(?)$ & & $(?)$ & & & & \\
\hline $\begin{array}{l}\text { Calcite } \\
\text { Tourmaline......... }\end{array}$ & $\begin{array}{l}10 \\
\text { Trac } \theta\end{array}$ & $<1$ & $<1^{5}$ & 3 & $<1$ & 12 & 5 \\
\hline Zircon & $<1$ & $<1$ & $<1$ & $<1$ & $<1$ & (n... & $<1$ \\
\hline Pyrite....... & $<1$ & & & $<1$ & 1 & & \\
\hline Leucoxene & 2 & 2 & 1 & 1 & 2 & & 1 \\
\hline Ilmenite & 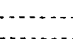 & 2 & 1 & 1 & 2 & & \\
\hline \multicolumn{8}{|l|}{$\begin{array}{l}\text { Magnetite.... } \\
\text { A patite... }\end{array}$} \\
\hline A patite..... & & & & & & & $<1$ \\
\hline
\end{tabular}

Estimated grain sizes, in millimeters

\begin{tabular}{|c|c|c|c|c|c|c|c|}
\hline $\begin{array}{l}\text { Large grains...... } \\
\text { Interstitial grains. }\end{array}$ & $\begin{array}{r}0.15 \\
.02\end{array}$ & $\begin{array}{l}0.3 \\
.01\end{array}$ & $\begin{array}{l}0.1 \\
.06\end{array}$ & $\begin{array}{l}0.2 \\
.06\end{array}$ & $\begin{array}{l}0.2 \\
.04\end{array}$ & $\begin{array}{r}\rightarrow 1.0 \\
.1\end{array}$ & $\rightarrow 0.3$ \\
\hline
\end{tabular}

Some properties of chlorite in the samples

\begin{tabular}{|c|c|c|c|c|c|c|c|}
\hline $\begin{array}{l}\text { (001) spacing - A } \\
\text { Sign of elongation. }\end{array}$ & $\begin{array}{c}14.10 \\
(+)\end{array}$ & $\begin{array}{c}14.10 \\
(+)\end{array}$ & $(+)_{(-)}^{14.10}$ and & $\begin{array}{c}14.12 \\
(+)\end{array}$ & $(+) \underset{(-)}{14.12}$ & $\begin{array}{c}14.15 \\
(-)\end{array}$ & $\begin{array}{c}14.13 \\
(+)\end{array}$ \\
\hline
\end{tabular}

1 Explanation given in description of fieldwork.

2 Determined to be muscovite by $X$-ray analysis.

1-5. Typical argillaceous sandstone of Frontenac Formation.

6. Probable volcanic sandstone.

7. Calcitic concretion.

The (003), (004), and (005) spacings of chlorite on X-ray analyses of total rock samples were averaged, using quartz as an internal standard. Basal spacings of $14.10,14.10,14.10,14.12,14.12$, and $14.13 \mathrm{~A}$ suggest an aluminum content per 10 cations of about 2.8-3.0.

Volcanic rocks occur within the Frontenac Formation northeast of the Attean quadrangle at Pittston Farm near the west end of Seboomook Lake and to the southwest in Quebec, but are absent in the Attean quadrangle. The metasandstones described above are like the schistose quartzites described by Marleau (1958b, p. 77-79) and unlike his greenstone and tuff $(1958 \mathrm{~b}, \mathrm{p} .75-76)$, which consist mainly of chlorite, acetinolite, clinozoisite, and plagioclase. An attempt was made to identify volcanic rock and sandstone containing a large amount of volcanic detritus. As compared to the average range given above, four thin sections from the Frontenac Formation within the Attean quadrangle have a rather low quartz content and high chlo- 
rite, clinozoisite, plagioclase, or white mica content. The chlorite from one of these rocks (sample 6, table 9) has a substantially greater basal spacing and lower aluminum content than chlorite of the typical argillaceous sandstone. As none of these have a composition like that of the volcanic rocks described by Marleau, it was concluded that these rocks are sandstones that contain a substantial amount of volcanic detritus. The typical sandstone may also contain some volcanic detritus.

The top of the Frontenac Formation is not preserved, but an estimate of thickness can be made from the southern basal contact to the core of the syncline. Dips along the southern border in the massive sandstone are much less than those well within the Frontenac, and an average dip of about $30^{\circ}$ seems reasonable. This angle gives a thickness of about 11,000 feet, but it seems necessary to allow for at least a twofold or threefold repetition by folding or faulting, or both. Thus, the thickness can only be given as several thousand feet or greater. By the same sort of reasoning, Marleau $(1958 \mathrm{~b}$, p. 92) estimated a thickness of 3,500 feet for the Frontenac Formation. Boucot (1961, p. 166) estimated that the Tarratine Formation, the proposed age equivalent of the Frontenac in the Moose River synclinorium, ranges from 10,000 to 1,000 feet in thickness.

Since the time of Logan's work (1849) the rocks now called the Frontenac Formation were regarded as the oldest rocks exposed in this area, mainly on the basis of similarities in lithology and topographic expression to the rocks of the Green Mountain-Sutton Range to the west. Ells $(1887$, p. 24-26) indicated virtually correctly the contacts of the Frontenac Formation and assigned it a Cambrian age; the slates to the west, equivalent to the Seboomook, were assigned a "Cambro-Silurian" (Ordovician in modern nomenclature) age; and the granofels unit to the east, a "Huronian" age. These assignments were based primarily upon correlation with Hitchcock's (1878) work in northern New Hampshire. Ells believed that there was a "well-defined anticlinal structure" within the Frontenac, and he did not recognize the narrow band of Seboomook between the Frontenac Formation and granofels unit. McGerrigle (1935), Lord (1938), and Faessler (1939) inferred essentially the same pattern; all believed that the Frontenac rocks were older than the rocks just to the west. Boucot (1953) assigned the Frontenac to the Cambrian and Ordovician and the granofels unit to the Precambrian.

Relationships on the west side of the Attean quadrangle may either be interpreted to indicate that the Frontenac Formation overlies the 
Seboomook Formation, which in turn overlies the pre-Upper Silurian rocks, or that the two units are bounded by a fault preserving previous assignments. Aeromagnetic maps (Canada Geol. Survey, 1953, 1954a-c; Boucot and others, 1960) indicate the extension of the narrow band of Seboomook from the west side of the Attean quadrangle southward into Quebec and back into Maine north of Parmachenee Lake. Reconnaissance work has confirmed the sequence (northwest to southeast) - Frontenac Formation, Seboomook Formation, pre-Upper Silurian units-in the area north of Parmachenee Lake. The Aeromagnetic maps also indicate two parallel narrow belts of high anomalies related to the rather high magnetic susceptibility of volcanic rocks within the Frontenac Formation. Marleau (1958a, b) concluded from the observation of top directions of pillow lavas that these volcanic rocks are on opposite limbs of a major structure, the Frontenac synclinorium, and he also traced the band of Seboomook through Quebec. Boucot (1961, p. 172; Boucot and others, 1960) revised his views on the age of the Frontenac Formation according to the inferred synclinorium and assigned the unit an Early Devonian age.

No direct evidence has been found to closely date the Frontenac Formation and to establish its stratigraphic position. Our work and that of Marleau indicate that the Frontenac probably crops out in the center of a major syncline; thus, it overlies the Seboomook Formation south and east of the synclinal axis, near the area of this report. The Compton Formation, which is equivalent to the Seboomook north and west of the axis in Quebec, is therefore by analogy also overlain by the Frontenac. In Maine, however, northeast of the Attean area the relative age of the Frontenac is equivocal because slates of Seboomook lithology are known to structurally overlie the argillaceous sandstone of the Frontenac Formation where the boundary may be either a gradational contact or a fault; thus, the Frontenac may be older, at least in part, than the Seboomook.

Argillaceous sandstone of the Frontenac Formation may be arbitrarily compared with that of the Tarratine Formation on a nonrigorous basis, and the slate and phyllite of the Frontenac Formation, except for a greener color, are casually comparable to those of the Seboomook Formation below. Thus, on the basis of lithologic comparison alone, the Frontenac may possibly be equivalent to the Tarratine Formation; therefore, an Early Devonian (Oriskany) age is tentatively assigned to at least the lower part of the Frontenac Formation and is arbitrarily adopted for purposes of this report.

\section{ROCKS OF EARLY DEVONIAN OR YOUNGER AGE}

Rocks assigned an Early Devonian or younger age include sills and dikes of hornblende diorite intruded into the Frontenac Formation, 
the Hog Island Granodiorite, and two small dikes altered to dolomite. The hornblende diorite is arbitrarily assigned an Early Devonian or younger age because it occurs only within the Frontenac Formation in the Attean quadrangle and has been affected by regional metamorphism. Should the Frontenac be older, then the age of the hornblende diorite would have to be reassigned accordingly. The Hog Island Granodiorite shows little alteration and was apparently intruded after or during the waning stages of regional metamorphism. The two altered dikes are within the Seboomook Formation and cannot be dated relative to the other two intrusive units.

\section{HORNBLENDE DIORITE}

Hornblende diorite crops out only within the Frontenac Formation in the Attean quadrangle. It occurs in elongate masses several feet to several hundred feet wide and in one more bulbous mass several thousand feet wide. All these masses are elongate parallel to the general structural trend, and all observed contacts at map scale are conformable to the strike of bedding and cleavage, but the nature of the outcrops does not permit us to ascertain conformity with dip. Folds in the vicinity of the largest mass suggest that its shape may be due in part to local repetition by folding. The restriction of the hornblende diorite to the Frontenac Formation might suggest an extrusive origin, but no primary volcanic features were observed and these rocks are quite unlike the volcanic rocks of the Frontenac Formation described by Marleau (1958b, p. 73-76). Several contacts have a suggestion of a finer grained margin, although now much altered and schistose. The hornblende diorite bodies, therefore, are indicated to have been intruded as sills in the Frontenac Formation. A linear aeromagnetic anomaly described in a later section is believed to be caused by a concealed dike, which may be related to the hornblende diorite as a feeder conduit.

Massive medium- to coarse-grained hornblende diorite forms high cliffs on the south side of Slidedown Mountain (NC-1.5, 4.41). A small outcrop of medium-grained pyroxene-bearing hornblende diorite is on U.S. Route 201 (NE-1.75, 4.52). More extensive exposures are on Sandy Stream Mountain.

The hornblende diorite is a medium-grained extremely massive rock which consists mainly of hornblende and plagioclase. It weathers to a speckled green and white hackly surface, but is dark green on a fresh surface. The diorite crops out boldly and forms many of the east-northeast-trending ridges in the northern part of the quadrangle. It is foliated only near the contacts of some of the larger masses and in a thin selvage zone at the contact of smaller masses. Small gobs or veins of hornblende, epidote, quartz, or chlorite are fairly common.

438-197-72-5 
Although the rock looks unaltered on a fresh surface, the hackly weathered surface is indicative of the high alteration and suggests that these rock masses are metadiorite or epidiorite.

The usual texture is interlocking bladed; randomly oriented laths of plagioclase are interstitial to coarser grained randomly oriented blades of hornblende (1-4 mm long). Rarely, plagioclase is the coarser grained mineral (1-2 mm long) and hornblende is interstitial to it. The texture has been affected by the alteration of hornblende and plagicoclase. Hornblende alters to actinolite, clinozoisite-epidote, chlorite, and rare biotite and calcite; plagioclase alters to aggregates of albite, clinozoisite, and white mica. Irregular or skeletal grains $(\approx 0.5 \mathrm{~mm}$ in diameter) of ilmenite are rimmed by sphene or leucoxene. Estimates of the original mineral content were made for 12 thin sections; the medial 10 values for each mineral are in the following range: $37-50$ percent hornblende and its alteration products, $40-60$ percent plagioclase and its alterations products, and 1-5 percent ilmenite-sphene-leucoxene.

The hornblende has the following properties: $2 \mathrm{~V}(-)$ $\approx 80^{\circ} ; Z \wedge c \approx 26^{\circ}$; and pleochroism, $X$, colorless; $Y$, light green; and $Z$, light blue green. The peripheries of hornblende grains are commonly altered to a felted aggregate of fine needles of actinolite, in which $Z \wedge c=15-20^{\circ}$. In many samples, hornblende contains cores of calcic pyroxene that has the following properties: $2 \mathrm{~V}(+)=65-70^{\circ}$; and $Z \wedge c \approx 41^{\circ}$. One sample contains peripherally altered grains of pyroxene $(\approx 3 \mathrm{~mm}$ long). Differences in the composition of both clinozoisite-epidote and chlorite in various samples are indicated by the range in critical optical properties. Chlorite commonly has a positive sign of elongation, which indicates that these grains contain more iron than magnesium.

The plagioclase is highly altered but retains a fuzzy multiple albite twinning; zoning is not obvious. Most of the remaining feldspar is albite, but optical properties indicate compositions as calcic as $\mathbf{A n}_{30}$ in a few grains. The amount of clinozoisite suggests that the original plagioclase was rather calcic. Minor minerals in addition to ilmenitesphene-leucoxene include pyrite, pyrrhotite, apatite, and rutile.

The diorite at the contact has been folded and foliated, indicating that it was emplaced prior to the post-Early Devonian metamorphism. The high alteration is attributed mainly to this metamorphism rather than to deuteric alteration.

The hornblende diorite in the Attean quadrangle intrudes the Frontenac Formation (Lower Devonian) and has been somewhat metamorphosed, presumably during the Acadian orogeny. Rocks similar to the hornblende diorite occur in the Frontenac Formation in 
adjacent Quebec (Marleau, 1958a; 1958̄b, p. 112-117). An elongate mass of ophitic diabase, about 4.5 miles long, is exposed within the Tarratine Formation immediately north of Parlin Pond in the Long Pond quadrangle. The mass is conformable and is a highly altered pyroxene-labradorite rock, according to Boucot (written commun., 1956). Boucot assigned a possible Early Devonian age to this mass because it is premetamorphic and post-Oriskany. It is likely that this body is equivalent in age to the hornblende diorite of the Attean quadrangle, if our age assignment is correct.

\section{ALTERED DIKES}

Two highly altered dikes intrude the Seboomook Formation in the Attean quadrangle ( $\mathrm{NC}-0.85,1.52 ; \mathrm{NC}-3.67,3.52)$; both are poorly exposed and consist of fine-grained dolomite.

The altered dikes are a fine-grained greenish-brown rock that has a thick orange-brown weathered surface rind. In thin section a porphyritic bladed texture is apparent, although the rock now consists of about 95 percent dolomite containing minor quartz, white mica, chlorite, and fine opaque minerals. The texture suggests that the original rock contained phenocrysts of feldspar and hornblende in a finegrained matrix, but none of the original minerals are preserved.

No logical correlatives of the altered dikes are known unless they are related to three quartz-feldspar porphyry dikes which intrude the Frontenac Formation in the Sandy Bay quadrangle, several miles north of the Attean quadrangle (Sandy Bay, SC-1.56, 2.39; SC-0.35, $2.06 ; \mathrm{SC}-0.45,1.50)$. None of the quartz-feldspar porphyry dikes are more than a few feet thick, and their total length could not be determined. Both types of dikes intrude Lower Devonian rocks, but no upper limit can be placed on their ages. In addition, quartzfeldspar porphyry dikes are abundant in the Frontenac southwest in Quebec (Faessler, 1939; Marleau, 1958b, p. 125-127), where scheelite was found associated with the dikes around 1890, and they have since been rather intensively explored (Marleau, 1958b, p. 140-141).

All these dikes may be related either to the Kineo Volcanic Member of the Tomhegan Formation of Early Devonian age in the Moose River synclinorium or to granitic rock like the Hog Island Granodiorite, which is of late Early or early Middle Devonian age.

\section{HOG ISLAND GRANODIORITE}

The Hog Island Granodiorite, herein adopted, forms a nearly circular stock, about 2.5 by 2 miles in diameter, which underlies part of the village of Jackman and much of Wood Pond. The stock is exposed in only two locations - the south shore of Hog Island in Wood Pond, 
the type locality, and the lower part of the steep northeast face of Sally Mountain on the south shore of Wood Pond. The granodiorite is here named for its good exposures on Hog Island. The contacts shown on the map are inferred largely from aeromagnetic data, because of the covering glacial deposits and lake. The stock is surrounded by a contact-metamorphosed aureole about 0.2 mile wide. Numerous building foundations and the church at the south end of Jackman village are constructed of blocks split from large erratic boulders of Hog Island Granodiorite.

The Hog Island Granodiorite is a medium-grained light-gray rock composed of biotite, plagioclase, quartz, and potassium feldspar. Potassium feldspar is commonly coarser grained (4-6 $\mathrm{mm}$ thick) than plagioclase (1-2 mm thick) and quartz (1-2 mm thick). Finer grains of all three minerals and some myrmekitic intergrowths occur along the boundaries of the larger grains. The rock is massive and only slightly jointed; thin dikes of aplitic facies of the granodiorite are rare in the few available outcrops.

The rock contains 40-55 percent plagioclase, 15-20 percent potassium feldspar, 20-35 percent quartz, and about 5 percent biotite. Minor minerals include hornblende, white mica, zircon, allanite, sphene, magnetite, and apatite - as well as chlorite, clinozoisite-epidote, calcite, and white mica, of probable secondary origin. Measured modes, obtained from point counts of stained thin sections, are given in table 10.

TABLE 10.-Measured modes of Hog Island Granodiorite, Attean quadrangle, Maine

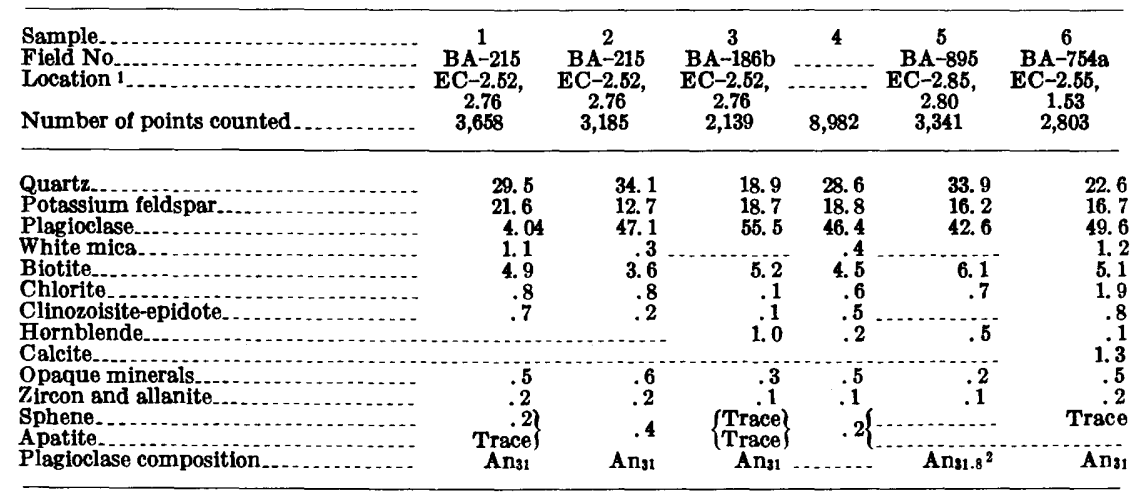

1 Explanation given in description of fieldwork.

${ }_{\alpha, 1.5447 ; 2 V \gamma}, 101.6^{\circ}$.

1-3. Point counts made on stained thin sections from various parts of outcrop from which samples for isotopic age determinations and chemical analysis were obtained.

4. Weighted average of samples 1-3.

5. Sample collected 1,200 feet east of samples 1-3.

6. Sample collected about 20 feet from contact with Upper Silurian conglomerate unit. Plagioclase highly altered to white mica, clinozoisite-epidote, and calcite. 
The potassium feldspar is a fine microperthite containing small amounts of patch perthite. It occurs in large anhedral grains, which poikilitically include smaller grains of quartz and feldspar. Plagioclase occurs in subhedral grains that have marked oscillatory zoning and is twinned according to the albite, pericline, and carlsbad laws. Individual grains have as many as 10 oscillations, but extinction angles indicate very little change in composition. The optical properties of plagioclase from one specimen (BA-895; $a=1.5447,2 V_{\gamma}$ $=101.6^{\circ}$, measured by a single variation method on the universal stage, indicate a composition of $\mathrm{An}_{31.8}$. Measured extinction angles on other specimens indicate the same composition. Plagioclase is somewhat altered to white mica, clinozoisite, and calcite, particularly in the more calcic zones. Biotite is pleochroic from dark brown to light greenish brown and is commonly in parallel intergrowths with white mica and chlorite. White mica, the subhedral habit of which suggests a primary origin, is found in those specimens without hornblende. Hornblende is found as small irregular grains and is unaltered. Allanite is found in markedly zoned and twinned subhedral crystals as much as $1 \mathrm{~mm}$ long, and sphene and magnetite are found as rather large subhedral crystals. Quartz has weak undulatory extinction.

Chemical analyses, CIPW norms, and calculated modes of the typical Hog Island Granodiorite are given in table 11. The measured and calculated modes for BA-215 are reasonably close. Muscovite is higher in the calculated mode because fine-grained white mica in feldspar was included with the host feldspar in the measured mode. Comparison of the values for biotite and magnetite suggests that part of the $\mathrm{Fe}^{+3}$ calculated as magnetite is actually in biotite.

The age of the Hog Island Granodiorite is inferred from several lines of evidence. The granodiorite intrudes the fossil-bearing Seboomook Formation (Lower Devonian), and fossils of probable Oriskany age have been collected from the cordierite hornfels of its contactmetamorphic aureole in that formation. In the Attean Quartz Monzonite, biotite that seems to have formed during the Acadian regional metamorphism has been recrystallized in the contact-metamorphic aureole of the granodiorite, and the granodiorite body itself is little altered; these relations indicate that the Hog Island Granodiorite was probably emplaced after the peak of the Acadian regional metamorphism.

The closest known areas in which the Acadian regional metamorphism has been dated are the Eastport area, where it is pre-Late Devonian (Bastin and Williams, 1914, p. 9-10), and the Presque Isle area, where it is pre-Middle Devonian-post-New Scotland (R. S. Naylor, Massachusetts Institute of Technology, written commun., 
1961). On this basis, the Hog Island Granodiorite is assigned here to the late Early or early Middle Devonian.

TABLE 11.-Chemical analysis, CIPW norm, and calculated mode of typical Hog Island Granodiorite, Attean quadrangle, Maine

[Chemically analyzed by methods described by Shapiro and Brannock, 1956. Modes calculated by assigning $\mathrm{Fe}^{+8}$ to magnetite, $\mathrm{T} i$ to sphene, $\mathrm{P}$ to apatite, $\mathrm{K}$ to provisional potassium feldspar, $\mathrm{Na}$ to sodium feldspar, $\mathrm{Cs}$ to calcium feldspar, remaining $\mathrm{Fe}+\mathrm{Mg}+\mathrm{Mn}=\mathrm{Fm}$ to biotite $\left[\mathrm{K} \mathrm{Fm}_{2.06} \mathbf{A l} 0.23\left(\mathrm{Al}_{1.33} \mathrm{Si}_{2} 80 \mathrm{O} \mathrm{O}^{10}\right)(\mathrm{OH})_{2}\right.$ using $K$ and $A 1$ from provisional potassium feldspar, remoining $A 1$ to muscovite $\left(K A l_{1}\left(A 1 S_{1} O_{10}\right)(O H)_{2}\right]$ using $\mathbf{K}$ and $A l$ from provisional potassium feldspar, and remaining $S 1$ to quartz. Actual mineral composition given in table 10. Laboratory number, 156030; field numbers, BB-2525a and BA-215; location EC-2.52, 2.76 (explanation given in description of fieldwork)].

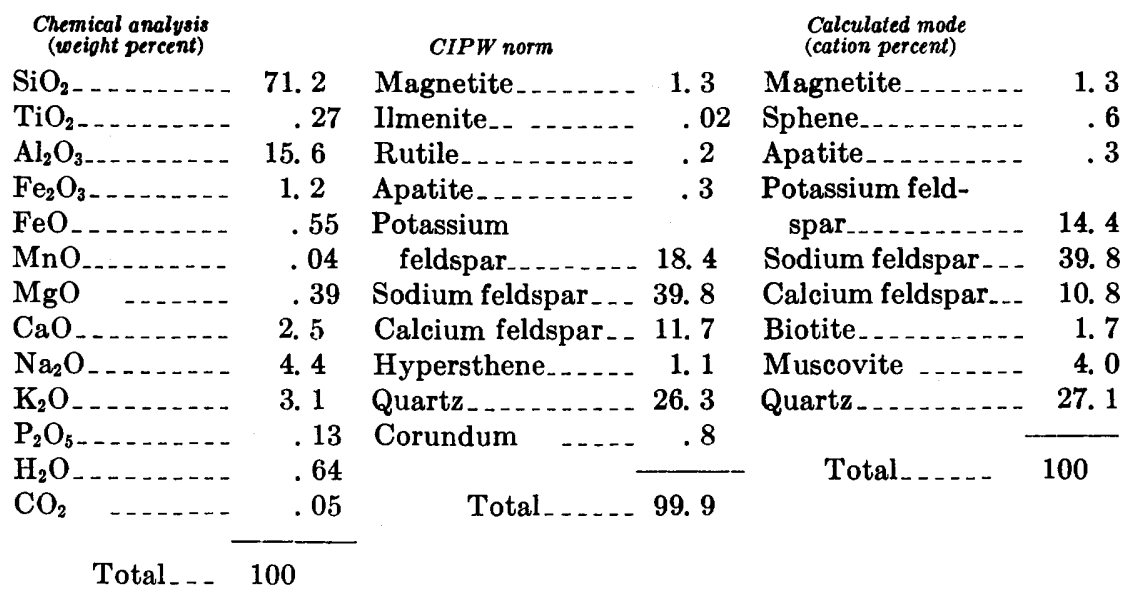

Isotopic age determinations (Hurley and others, 1959), which are discussed in a later section, indicate an age of about 360 m.y. (million years) for the Hog Island Granodiorite. Comparison with potassiumargon ages of $385 \pm 15$ m.y. for Oriskany-age bentonite beds in Gaspé (Smith and others, 1961) suggests that the Hog Island Granodiorite be assigned to the Middle Devonian.

Many stocks of similar rock are present elsewhere in Maine, and the New Hampshire Plutonic Series (Devonian) of New Hampshire (Billings, 1956 , p. 53-69, 106) includes plutons that are similar in lithology and structural setting.

\section{CONTACT-METAMORPHIG ROGKS ASSOGIATED WITH THE HOG ISLAND GRANODIORITE}

Within the contact-metamorphic aureole of the Hog Island Granodiorite, rocks of the Seboomook Formation, the conglomerate unit, and the Attean Quartz Monzonite are quite different from their normal lithologies, and each is described separately.

The Seboomook Formation in the inner 0.2 mile of the metamorphic aureole is a dark-gray cordierite hornfels; the hornfels is well exposed 
on an island in Wood Pond (EC-2.00, 2.64). Sedimentary layering and graded bedding are well preserved and are more apparent than in the normal slate of the Seboomook. Identifiable fossils have been found in the contact aureole; they are more easily distinguished in the hornfels than in the slate. Transverse cleavage is poorly formed, but some small tight relict flexures are enclosed within cordierite porphyroblasts. Blocky cordierite porphyroblasts, typically 5 by 5 by $10 \mathrm{~mm}$, are most abundant in the more argillaceous layers and may constitute $25-35$ percent of these layers. Cordierite distribution in the more argillaceous layers emphasizes the graded bedding. The matrix consists of about equal parts of quartz (and plagioclase?) and micaceous minerals (biotite, white mica, and chlorite) and 1-5 percent of very fine grained opaque minerals, chiefly graphite. Quartz grains in the more quartzose layers are coarser grained $(0.4-0.6 \mathrm{~mm}$ diameter $)$ than those in the more argillaceous layers $(0.1-0.2 \mathrm{~mm}$ in diameter $)$.

The cordierite porphyroblasts, which may consist of more than one one crystal, commonly contain inclusions of quartz, white mica, and chlorite, and many have rims of white mica and chlorite. Brown biotite constitutes as much as 30 percent of the matrix near the contact, but chlorite becomes more abundant and biotite, less abundant away from the contact. Both biotite and chlorite are present in samples collected about 0.6 mile from the contact; these samples look like the typical slate of the Seboomook. Biotite was absent, however, in rock 1.3 miles from the contact. The actual contact between the Hog Island Grandiorite and the hornfels was not observed in place, but a large block on the shore at the southwest corner of Hog Island shows that the contact is sharp and without gradation or a selvage zone and that the rock does not break readily at the interface. The quartz and cordierite layering is cut at nearly right angles by the contact. Granodiorite at the contact is finer grained than in the typical granodiorite, and biotite is less abundant. In thin section the texture and mineral composition of the hornfels is unchanged adjacent to the main contact, but adjacent to a thin (10 mm thick) dike in the same block, biotite has altered to chlorite, and cordierite, to white mica and biotite. No montmorillonite, kaolinite, or mixed-layer minerals were observed.

Within the contact-metamorphic aureole calc-silicate minerals occur in the calcareous sandstone and conglomerate of the conglomerate unit. The rock does not look different, except very close to the contact where calc-silicate minerals are megascopic. Such rocks can be seen on the west side of Wood Pond (EC-2.51, 1.52; EC-2.08, 2.09). Under the microscope the texture is not very different from that of the normal rocks of the conglomerate unit, but the detrital texture is somewhat parasitic and grain contacts are sutured. Garnet and pyroxene are 
interstitial to larger grains of quartz and feldspar. The garnet is zoned by color and birefringence and is probably grossularite-andradite; the pyroxene is diopside. The distribution of garnet and pyroxene seems irregular and must depend in part upon the distribution of calcite in the sandstone and conglomerate. Garnet and pyroxene were observed 0.2 mile horizontally from the contact, near the top of the steep east slope of Sally Mountain; it is not known exactly how far this occurrence actually was from the contact which now is exposed only at the foot of the slope. The conglomerate at the top of the east slope of Sally Mountain is calcareous, but no garnet or pyroxene was seen in it.

Several outcrops of Attean Quartz Monzonite occur just south of the inferred contact with the Hog Island Granodiorite (EC-3.45, 1.13). The rock in these outcrops has been recrystallized in the contactmetamorphic aureole. The normal Attean Quartz Monzonite contains abundant aggregates of chlorite, white mica, epidote, and green biotite, in part pseudomorphic after biotite. This green biotite has the same potassium-argon age as the Hog Island Granodiorite, the cordierite hornfels, and the slate of the Seboomook Formation (described in a later section). Such green biotite, however, is not present in the contact-metamorphic aureole, where it seems to have been recrystallized. The aureole rock contains aggregates of brown biotite, but chlorite, white mica, and epidote are absent in the aggregates. The feldspar shows evidence of enlargement, no clinozoisite is present in the plagioclase, and both quartz and feldspar contain healed granulation layers. Moreover, the magnetic susceptibility is four to five times that of the normal Attean Quartz Monzonite.

\section{STRUCTURAL GEOLOGY}

The Boundary Mountain anticlinorium (Cady, 1960, p. 536; Albee, 1961), a major structural feature, extends from northern New Hampshire northeast into the Attean quadrangle. In the central part of the quadrangle, the pre-Upper Silurian rocks in the core of the anticlinorium plunge under the Upper Silurian and Lower Devonian rocks; here, the anticlinorium is subdued and is expressed only as an anticlinal tract between two major synclinoria. The Moose River synclinorium (Boucot, 1953, 1961) lies east of the Attean quadrangle and contains a great thickness of well-dated Lower Devonian rocks. The Frontenac synclinorium to the west (Marleau, 1958b) also contains a great thickness of Lower Devonian rocks and is an "axial synclinorium" of the Connecticut Valley-Gaspé synclinorium (Cady, 1960, p. 536). The troughline of the Frontenac synclinorium passes through the extreme northwest cormer, the Quebec part, of the Attean quad- 
rangle and lies along the South Branch of the Penobscot River in the Sandy Bay quadrangle. The axes of all these major folds trend generally northeast, are nearly parallel, and have nearly horizontal plunges.

The Boundary Mountain anticlinorium is best expressed within the Attean quadrangle by the pattern of the unconformable contact between the pre-Upper Silurian and the Upper Silurian and Lower Devonian rocks. Bedding near the base of the Upper Silurian and Lower Devonian rocks is generally parallel to this contact, although it is transverse to the contact, tightly folded, and intensely cleaved a few hundred feet away. In the younger rocks in the western part of the area, bedding is rarely apparent, and cleavage is nearly parallel to cataclastic foliation in the underlying Attean Quartz Monzonite adjacent to the unconformity. No axial region can be located directly in the pre-Upper Silurian rocks, perhaps owing to the lack of planar features.

In contrast to the intense folding and extensive transverse cleavage found in the younger rocks, the pre-Upper Silurian rocks have deformed mainly by fracture and by local shearing produced by cataclasis (see earlier section).

The character of the deformational features, and presumably of the deformation itself, in the pre-Upper Silurian is very different from that in the Upper Silurian and Lower Devonian rocks; hence, the structural features of the two groups of rocks are discussed separately in the following sections.

\section{STRUCTURAL FEATURES IN PRE-UPPER SILURIAN ROCKS}

Fractures and joints, cataclastic zones, and faults-all features related to deformation by fracture-are the dominant structural features in the pre-Upper Silurian rocks. No folds were observed, but planar features by which folding might be recognized are extremely rare in the pre-Upper Silurian units.

Fractures are best formed and most systematic in the Attean Quartz Monzonite, where joints occur in well-formed sets. Most of these joints are simple fractures, devoid of slickensides, mineral fillings, or associated alteration. The joint surfaces are not curved and the joints have not been folded. Joint spacings vary greatly.

Fractures in the granofels unit and the diorite differ from those in the Attean Quartz Monzonite. Fractures in the granofels are extremely abundant but occur in local sets which have very irregular surfaces, rather than in through-going joint sets; systematic orientations are rare, even within a single outcrop. Even in outcrops where fractures are not apparent, the granofels and diorite tend to break 
along fracture surfaces; this tendency makes it difficult to procure specimens that have fresh surfaces. Slickensides, elongate aggregates of minerals, and preferentially oriented platy minerals suggest that movement has occurred on some fractures. Fractures filled with epidote, quartz, or feldspar are common in both rock types.

The difference in the fracturing characteristics of the Attean Quartz Monzonite from those of the granofels and diorite is inferred to be related to dissimilar textural and compositional properties, and not to the age of deformation.

Glacial quarrying accentuates the joints in much of the area and has produced lineaments that have marked topographic expression. Such topographic expression of joints in the Attean Quartz Monzonite is clearly shown on the aerial photographs (fig. 4), but topographic expression of fractures in the granofels and diorite is much less pronounced. This lack of expression is probably attributable to the rather irregular habit of the fractures in the granofels and diorite. The linear features expressed on the aerial photographs have been transferred to the bedrock geologic map (pl. 1). One or two joint sets are strongly expressed by lineaments over several large areas, but this expression is a function of the direction of glacial flow, as well as of the nature and spacing of the joint set.

Several schistose shear zones occur within the pre-Upper Silurian rocks, particularly the Attean Quartz Monzonite. These zones have no apparent linear extent at map scale, and the shearing has produced cataclastic deformation in combination with alteration of both the feldspars and mafic minerals. Parallelism of these zones with joints suggests they are genetically related. Several typical zones east of Attean (SE-1.0, 5.3) contain quartz porphyry dikes and abundant mafic inclusions. A geochemical anomaly at the east end of Sally Mountain is explained by the presence of sulfides within one or more of these shear zones (Canney and Post, 1964); the introduction of sulfides is manifested by alteration within the zones.

Within the pre-Upper Silurian rocks only the more persistent, wellexpressed fracture sets were measured; this method was especially adaptable to the Attean Quartz Monzonite, but interpretation was usually necessary in the granofels and the diorite. In most natural outcrops one, two, and rarely three fracture sets were measured; the prominent sets are commonly nearly vertical and less commonly nearly horizontal. However, in cliff exposures on the shores of Holeb and Attean Ponds and in railroad cuts, commonly more than three equally prominent fracture sets occur, only two of which are nearly vertical. Apparently, the measured distribution of the joint sets and topographic linear features is biased by glacial erosion and the direction of ice movement. 


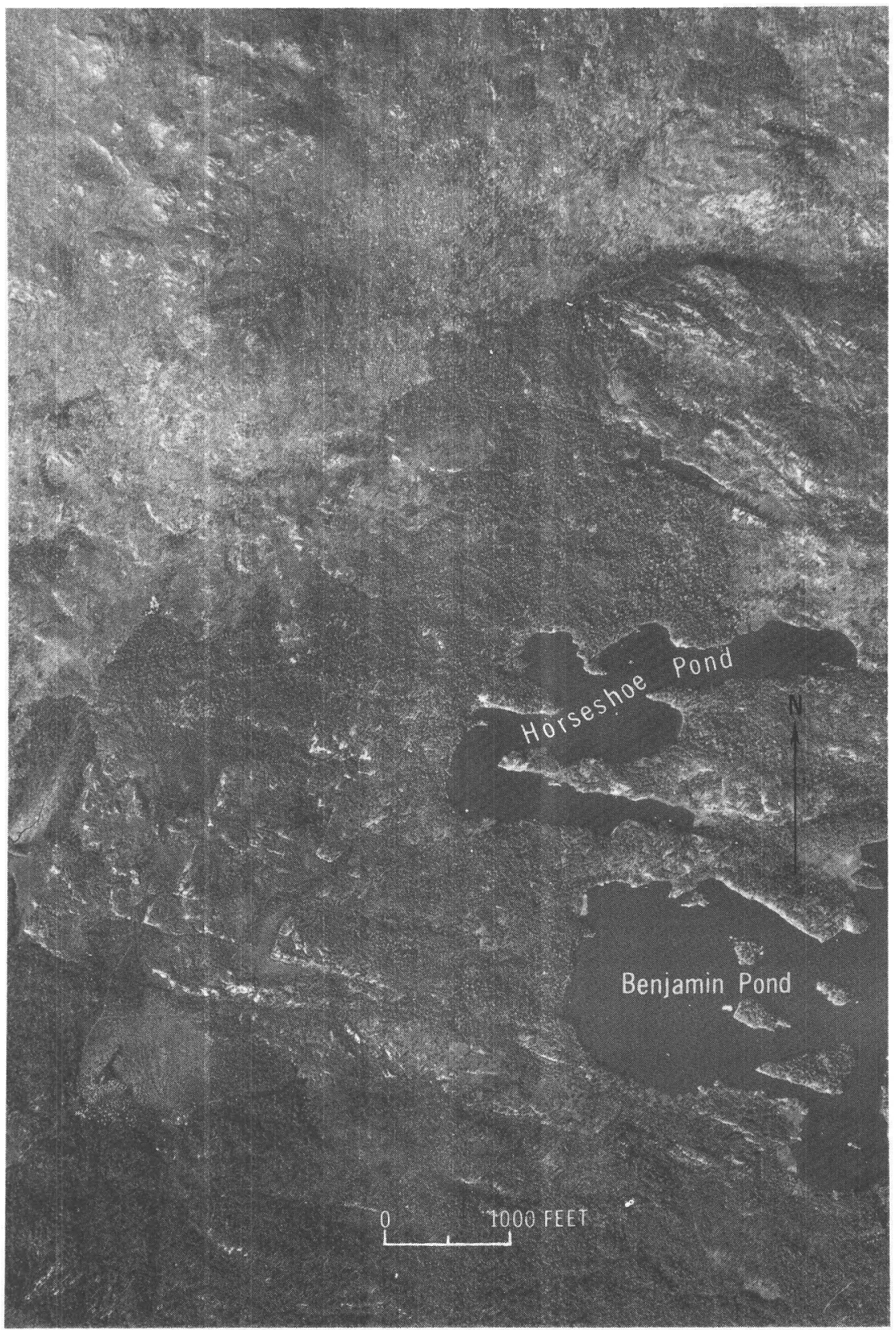

FIGURE 4.-Aerial photograph showing small ponds and cliffs along topographic lineaments resulting from glacial quarrying of well-jointed Attean Quartz Monzonite in the vicinity of Benjamin Pond, Attean quadrangle, Maine. Scale about $1: 20,000$. 


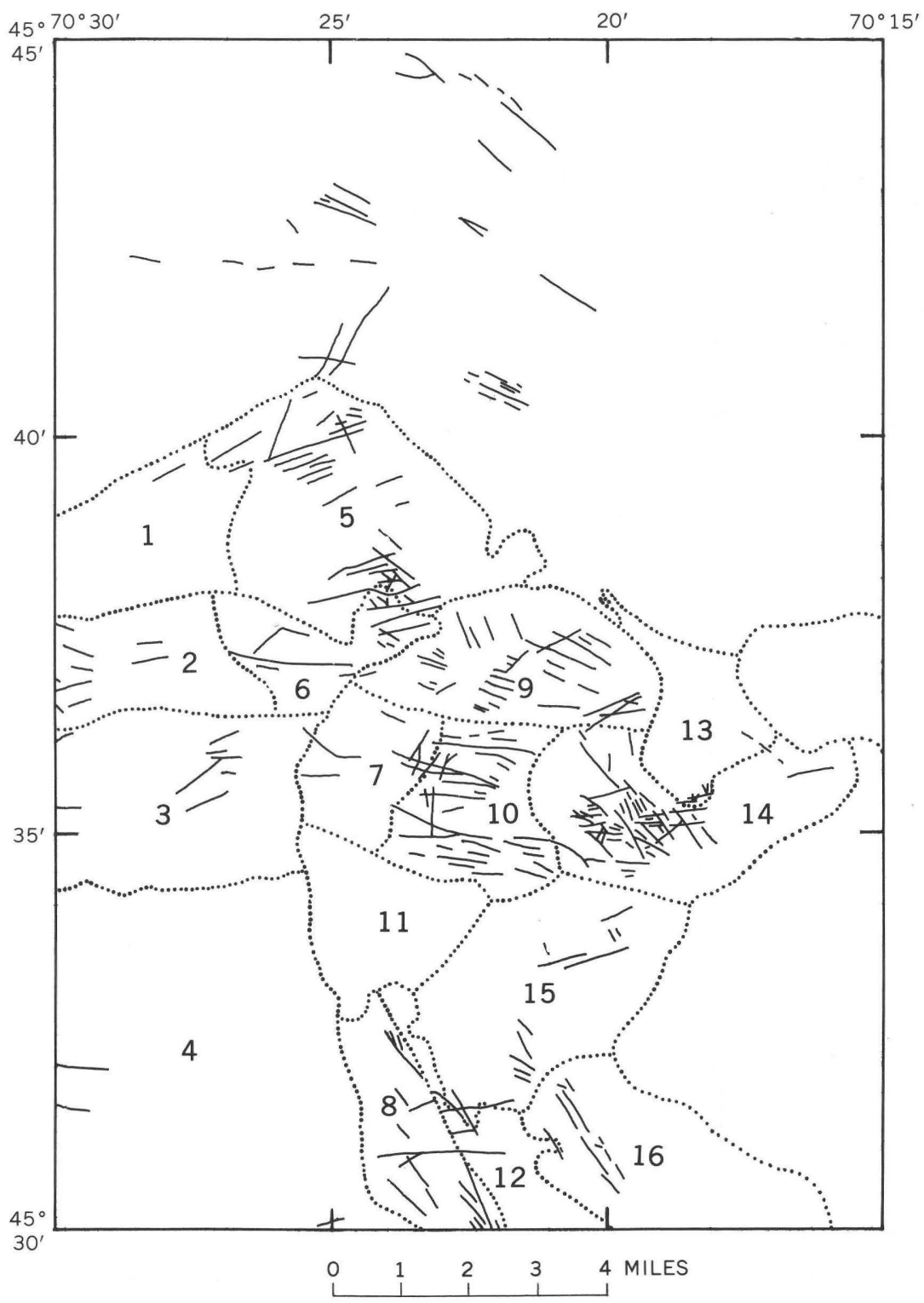

$\begin{array}{llllll}0 & 1 & 2 & 3 & 4 & \text { KILOMETERS }\end{array}$

Figure 5.-Point diagrams (on facing page) of joints (plotted on equal-area projection, upper hemisphere) from 16 areas within the Attean quadrangle, and map (above) showing location of these areas and topographic linear features plotted from aerial photographs.

Field measurements of joints in the pre-Upper Silurian rocks have been compiled into point diagrams, which are shown in figure 5 

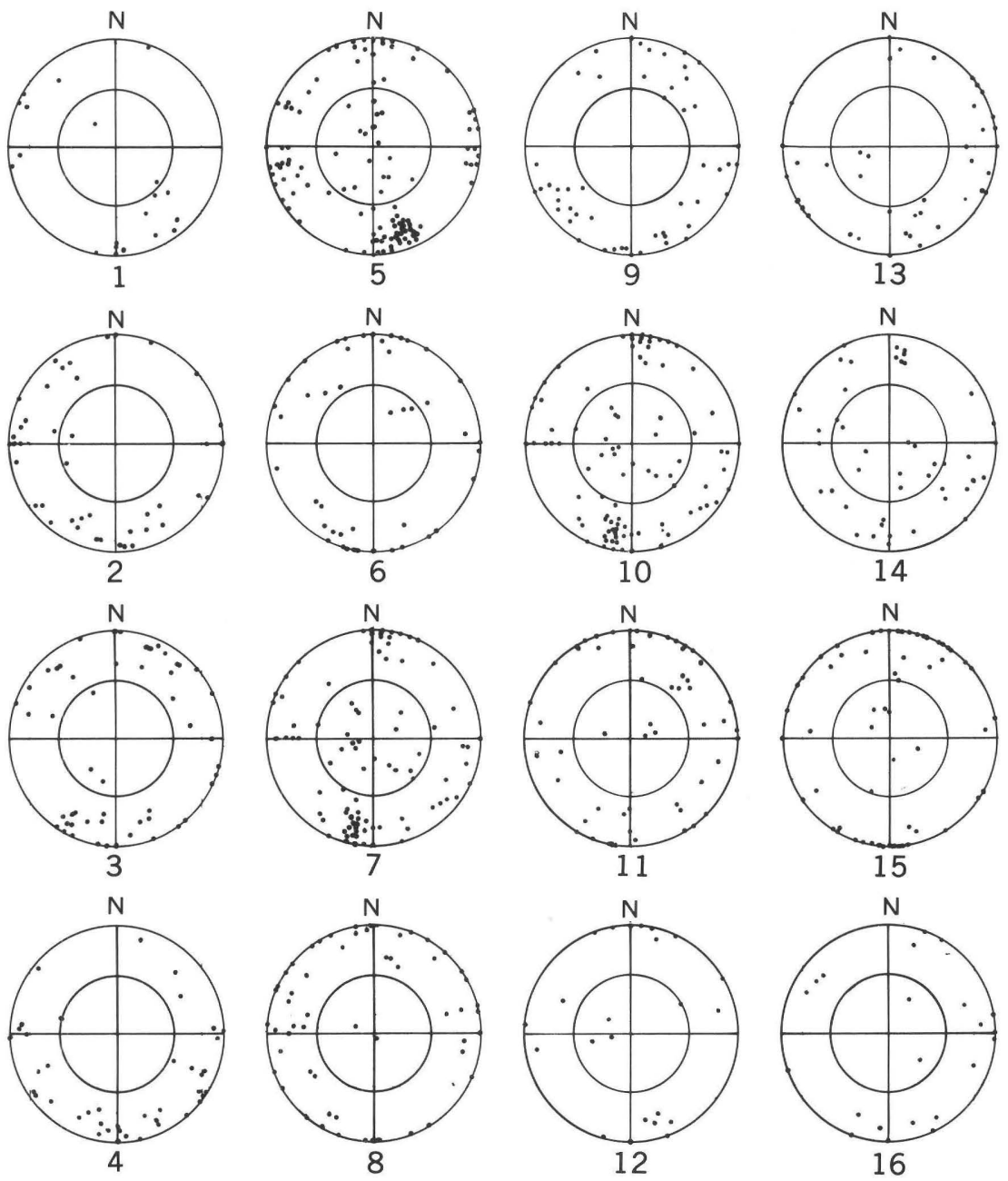

along with the topographic linear features. An individual point diagram has been prepared for each area of pre-Upper Silurian rocks bounded by either geologic contacts or extensive breaks in outcrop density, such as lakes or areas of thick till. A point diagram is also shown for the Upper Silurian conglomerate unit (area 13).

The trends of the joints (fig. 5) closely correspond to the trends of the topographic linear features, especially in the central part of the area. Point diagrams for two areas north of Attean and Holeb Ponds show the presence of more nearly horizontal fractures (dots in center of diagram) than in other areas. We interpret this to be the influence of the concentration of cliff exposures and railroad cuts in this area; these features favor observation of nearly horizontal fractures. On the other hand, differences in strike of the nearly vertical joint sets 
among fracture areas, as indicated by both the point diagrams and the topographic linear features, are interpreted to be real.

The planarity of aplite dikes suggests that these occupy fractures, but the aplite dikes generally occur singly, rather than in sets, and relatively few measurements were made on them. Some joints in the Attean Quartz Monzonite contain a thin clinozoisite-epidote filling. These filled joints occur in a peripheral alteration zone of the quartz monzonite which is rich in clinozoisite-epidote and chlorite. These joints are cut by younger simple fractures, but not enough of them were observed to permit any generalizations about their spatial relations.

The cataclastic schistosity in the Attean Quartz Monzonite north and west of Little Big Wood Pond (described in an earlier section) is best formed adjacent to the northeast-trending contact with the younger rocks. This rather distinct zone extends northeastward (pl.1) from the western edge of the quadrangle to the vicinity of the North Branch of Wood Stream, where the zone apparently extends into the Upper Silurian and Lower Devonian rocks along its trend. The schistosity is best formed within several hundred feet of the contact with the younger rocks, but it is still well formed as much as 4,000 feet from the contact. In this zone the micas derived from alteration of feldspar are alined, as are the deformed lenticular quartz grains; this alinement gives the rock a true micaceous schistosity (fig. 3). The schistosity is parallel to cleavage in the overlying Seboomook Formation and is slightly transverse to the contact. Simple joints and local irregular fractures transect the schistosity.

This cataclastic schistosity is expressed topographically as shown in area 5 in figure 5 . It has also been assumed (pls. 1,2) that this cataclastic zone passes upward and eastward into a multiple fault zone and is expressed by a combination of folds and faults in the Upper Silurian and Lower Devonian rocks.

A north-northwest-striking fault within the pre-Upper Silurian rocks extends for nearly half the quadrangle and probably at least 4 miles south into the Spencer Lake quadrangle. Attean Quartz Monzonite on the west has been faulted into contact with an elongate roof pendant of the granofels unit on the east; the fault is probably near vertical, and the downthrown block is on the east. Evidence for the fault includes the topographic expression and cataclastically deformed and altered rocks which crop out at several places within the narrow trench at the southern end of the quadrangle. It is not believed that this fault differs fundamentally from the cataclastic zones described immediately above, inasmuch as the zone parallels prominent joint sets in the adjacent rock on either side. 


\section{STRUGTURAL FEATURES IN UPPER SILURIAN AND LOWER DEVONIAN ROCKS}

The dominant observable structural feature of the Upper Silurian and Lower Devonian rocks is a cleavage transverse to bedding in the pelitic rocks. Evidence of map-scale folds was found in only a few places. One of these folds is an anticline on the east ridge of Slidedown Mountain; it is marked by reversal of dips of beds. This anticline may be responsible for the bifurcation of the east end of the hornblende diorite mass at Slidedown Mountain. The broad part of the mass is on the axial region of the anticline.

Several folds have also been mapped in the area northwest of Foxs Camp, and irregularly spaced areas of crumpled bedding in the northern part of the area underlain by the Seboomook Formation may indicate the positions of axial regions of larger folds. Even minor folds are rare, however, and the overall nature of the deformation must be inferred from the character of the minor structures and from observations in two roadcuts. Attitudes of several different minor structural features are indicated on the bedrock geologic map (pI.1).

Bedding in the limestone and slate unit and in the conglomeratic sandstone unit is readily distinguishable, but it is rarely observable in the Upper Silurian conglomerate unit. The massive argillaceous sandstone beds of the Frontenac Formation rarely have internal bedding, but the attitude of the contact with the surrounding pelitic rocks is generally observable. Bedding in the pelitic rocks of the Upper Silurian and Lower Devonian units is not everywhere obvious; it ranges from lithologic layering and rather spectacular cyclic layering produced by graded sets to nearly massive rocks in which layers are subtly expressed by refraction of cleavage, gradation in weathering color, or fine-grained sand layers as little as $1 \mathrm{~mm}$ thick. Graded bedding is commonly observable in thin section, even in rocks from outcrops in which bedding was not recognizable in the field. $\mathrm{A}$ bedding schistosity is produced by parallel orientation of micaceous minerals, but it is commonly almost totally disrupted by the transverse cleavage.

The transverse cleavage has a characteristic mineral fabric, spacing, and orientation relative to bedding and ranges from typical slaty (axial-plane, flow) cleavage to fracture cleavage. In fine-grained highly micaceous rocks the transverse cleavage is megascopically a slaty cleavage, seemingly produced by a uniform parallel orientation of micaceous minerals (fig. 6). Most thin sections indicate that the cleavage consists of thin discretely spaced planes, $0.02-0.04 \mathrm{~mm}$ apart. Between these planes the micaceous minerals are oriented parallel to bedding, and microscopic graded bedding is commonly preserved. In figure 6 , discrete offsets of bedding can be seen along the cleavage 


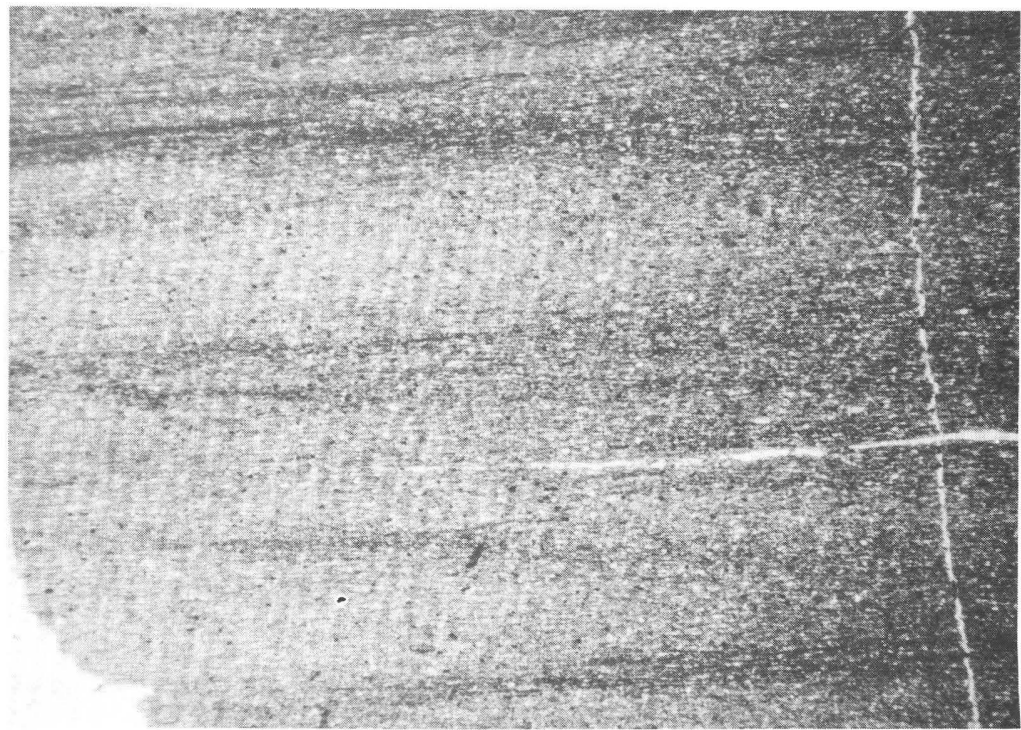

$A$

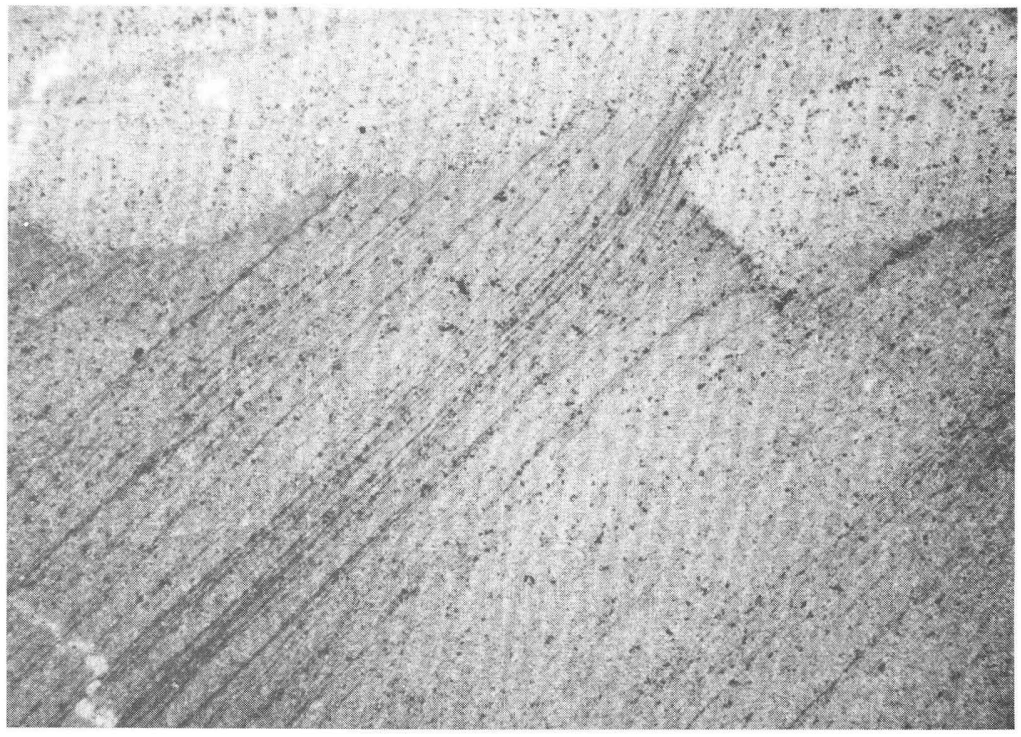

$B$

$3 \mathrm{~mm}$

FIGURE 6.-Photomicrographs of transverse cleavage in Upper Silurian and Lower Devonian pelitic rocks showing direct correlation of spacing of cleavage planes with grain size and percentage of granular minerals (plane-polarized light). $A$, Transverse cleavage planes spaced $0.01-0.02 \mathrm{~mm}$ apart; micaceous 
planes. Increased spacing of the cleavage planes correlates with increasing grain size and an increasing fraction of granular minerals.

In highly micaceous rocks a rare cleavage, spaced $5 \mathrm{~mm}$ apart, is found associated with chevron folds (fig. 7A). More commonly, however, the more widely spaced cleavage is a slip cleavage (White, 1949) characterized by fine crinkles in the mica fabric between the cleavage planes (fig. $7 B$ ). In highly quartzose beds the cleavage may be very widely spaced or absent, even though distinctive slaty cleavage occurs in adjacent pelitic beds.

Varied spatial relations of the transverse cleavage to bedding can be observed throughout the Devonian rocks. The transverse cleavage is refracted at the contacts between granular and micaceous beds and makes a smaller angle with bedding in the finer grained, more micaceous beds than in the coarser grained, more quartzose beds. The attitude of the intersection with bedding is the same in both rocks. This refraction of cleavage is not due to bending or offset after the formation of the cleavage; this is best demonstrated by the character of refracted cleavage in rocks containing well-formed graded bedding. (See fig. 8.) The cleavage forms a sigmoid curve across the graded sequence and is more closely spaced in the micaceous layers. Even where graded bedding is not readily apparent in the field, its existence is

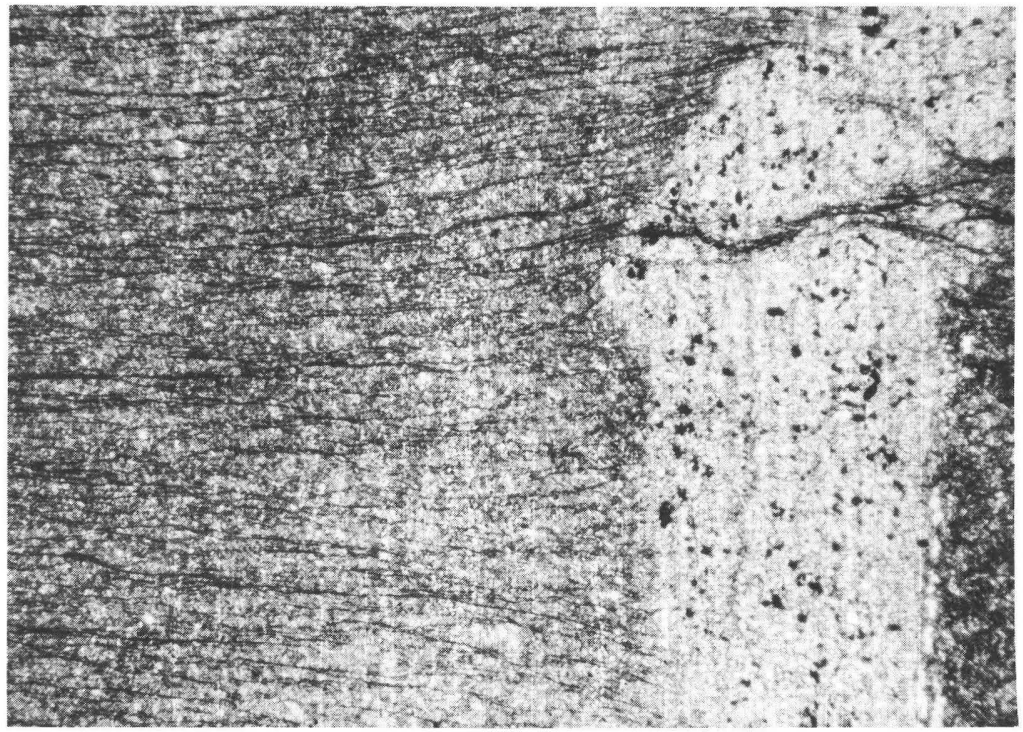

C

minerals in the slices are oriented transverse to cleavage. $B$, Transverse cleavage planes $0.05-0.2 \mathrm{~mm}$ apart. $C$, Transverse cleavage planes spaced $0.1-0.2 \mathrm{~mm}$ apart. Mica oriented parallel to bedding.

$428-197-72-6$ 
commonly indicated by the curvature of the transverse cleavage, and the curvature can be used to determine bedding tops.

The plane of the transverse cleavage is the plane of maximum flattening in the rock, although the presence of offsets might lead one to think it was a plane of maximum shear. Concretions observed through-

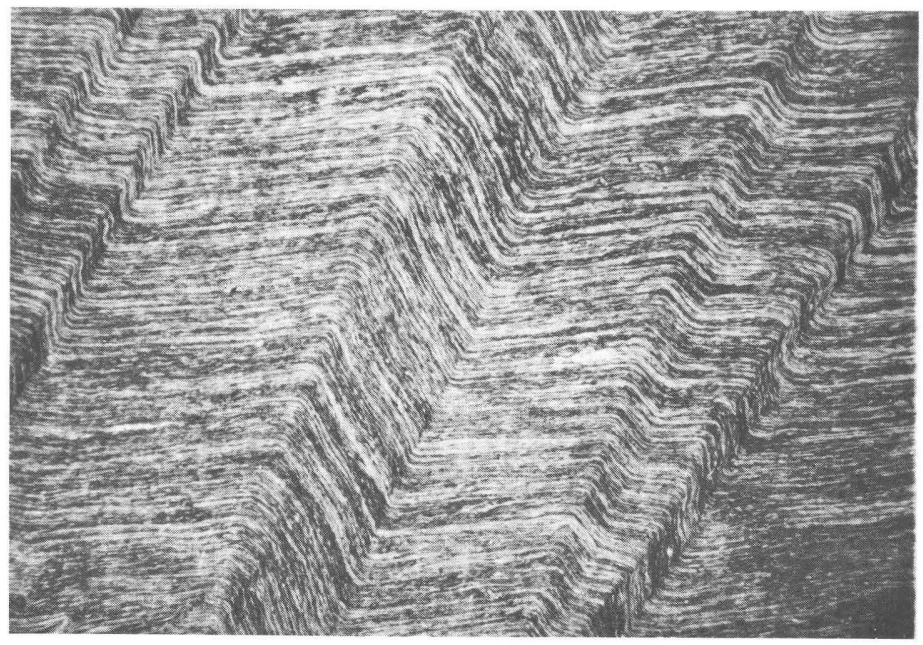

$A$

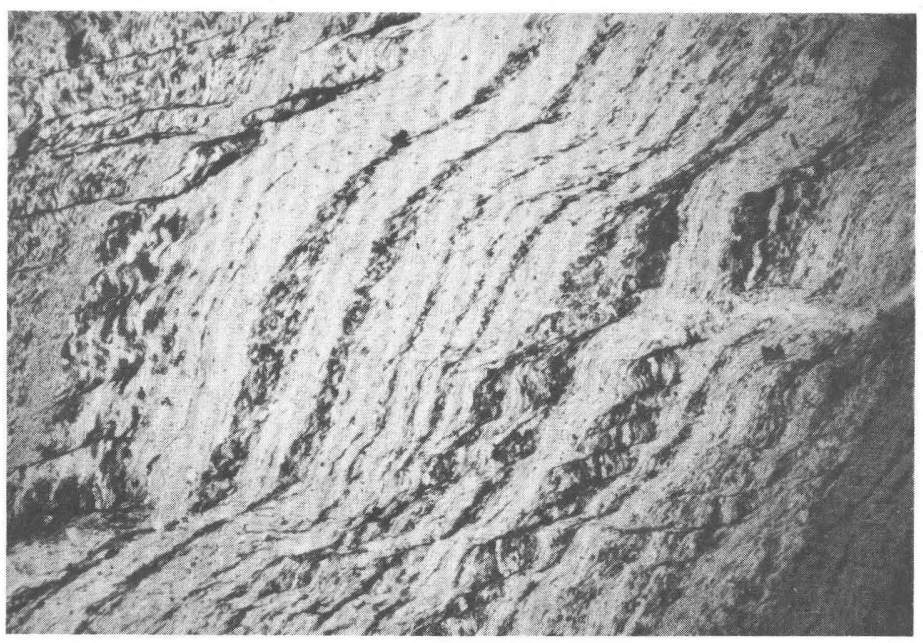

$B$

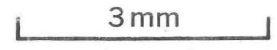

Figure 7.-Photomicrographs showing widely spaced transverse cleavage in Upper Silurian and Lower Devonian pelitic rocks. (Plane-polarized light.) $A$, Cleavage associated with chevron folds. $B$, Slip cleavage. 


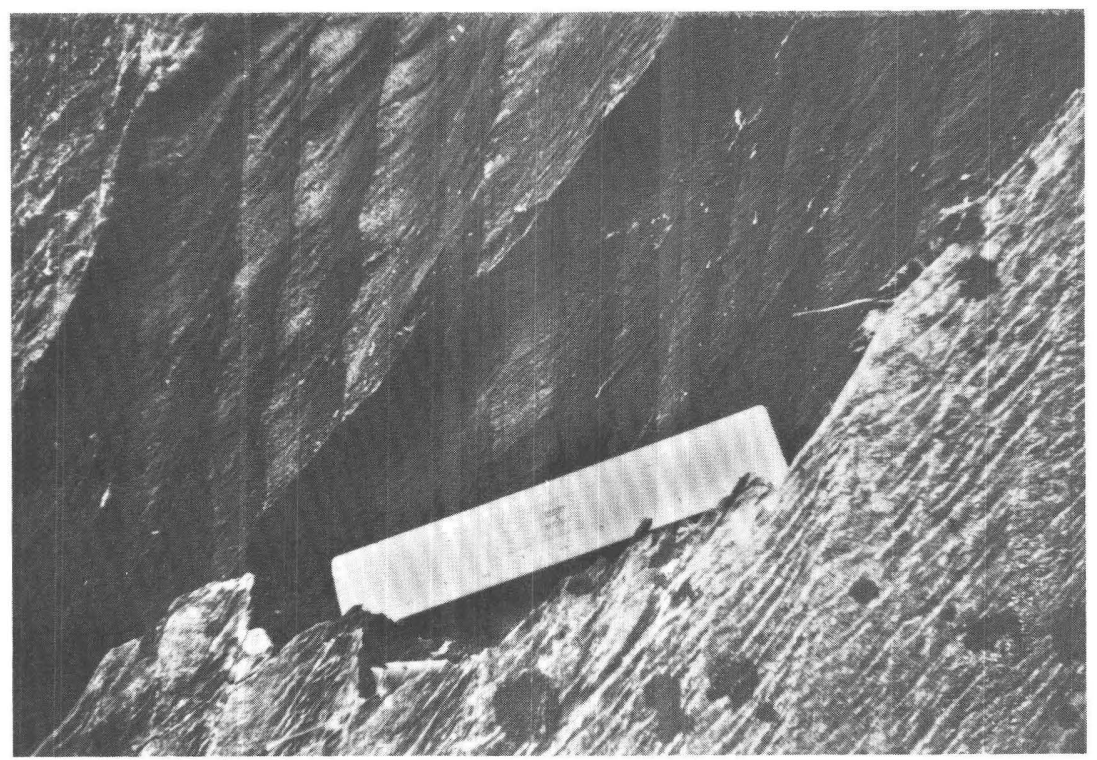

Figure 8.-Refracted cleavage in graded beds in the Seboomook Formation. Bedding is nearly vertical and the coarser grained rock is on the left in each graded bed. Ruler is 6 inches long.

out the area are all flattened in the plane of the transverse cleavage, and brachiopods from the vicinity of Foxs Camp (particularly fossil loc. BA-999, pl. 2) are markedly flattened in the plane of cleavage, as indicated in figure 9 .

In folds, the transverse cleavage coexists with concentric shear in sandy layers, as in the examples discussed and figured by De Sitter (1956, p. 93-98). Figure 10 shows several slabs cut from a single small fold in a rock containing alternating sandy and micaceous layers, and figure 11 shows similar features in photomicrographs. On the flanks of the fold, the dark-gray micaceous layers are thinned relative to the hinge area owing to the closely spaced transverse cleavage. However, the sandy layers have apparently deformed by both concentric shearing parallel to bedding and concentrated transverse slip.

A structural feature which consists of rather widely spaced monoclinal flexures that pass into partings or small faults, herein called fold-band structure, offsets the transverse cleavage; the offset direction is generally consistent within a small area, but no regional systematic pattern is apparent. The apparent lack of system, however, may be the result of our failure to observe the features in small outcrops. Persistent well-expressed joint systems are not common in the Upper Silurian and Lower Devonian rocks, but these fold bands may essen- 


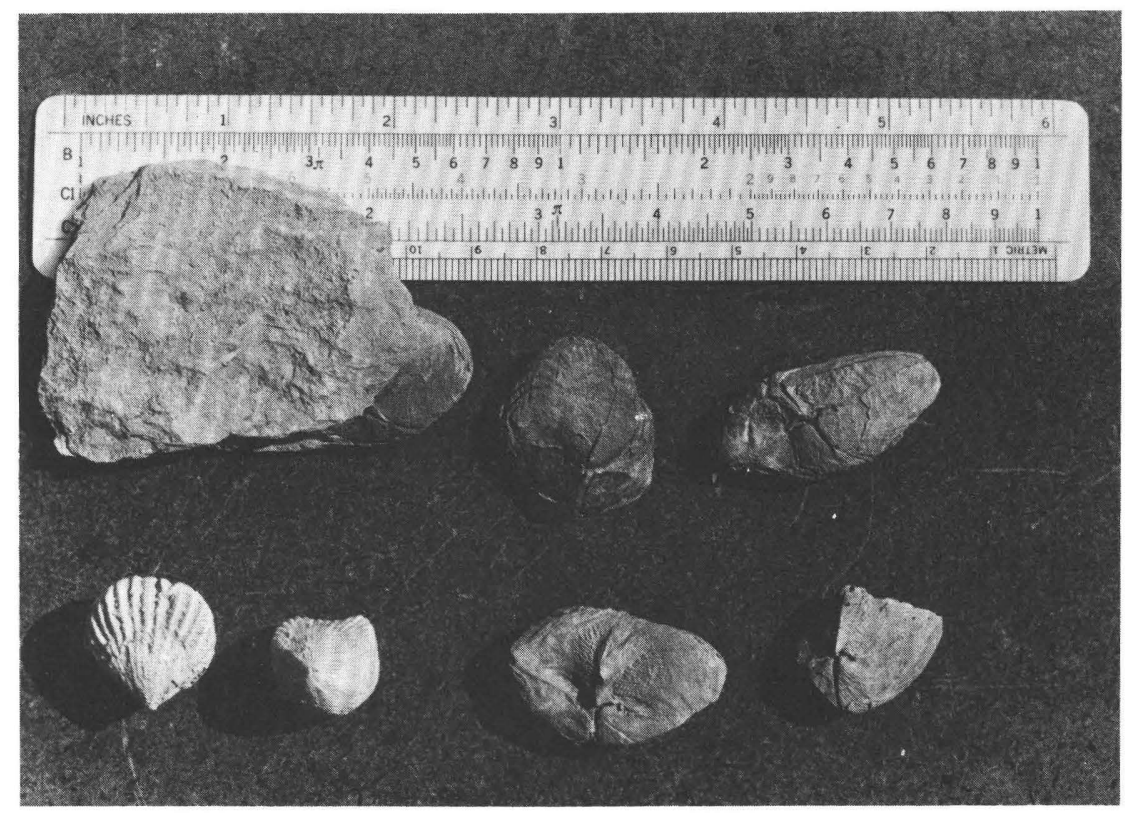

Figure 9.-Fossils (brachiopods) flattened in the plane of cleavage from calcareous slate near Foxs Camp, Attean quadrangle, Maine (fossil loc. BA-999). Sample in upper left is a slate fragment lying on the cleavage plane; a flattened brachiopod protrudes from the right side. The two specimens in the lower left are undeformed examples of the same species but from another locality. The undeformed specimen on the right has the same orientation as the flattened specimens.

tially be the equivalent of joints. Fractures, but no fold bands, are formed in the hornblende diorite bodies and in the boulder and cobble conglomerate of the conglomerate unit.

In the southern part of the Seboomook terrane, bedding commonly dips $15^{\circ}-30^{\circ} \mathrm{WNW}$, and the transverse cleavage dips $35^{\circ}-60^{\circ} \mathrm{NW}$. The dips of both features steepen in the area to the north underlain by the Frontenac Formation. The cleavage-bedding intersection is parallel to the axes of small crinkles where they are present; both commonly plunge less than $10^{\circ} \mathrm{NE}$., but are locally near horizontal or plunge gently southwest. The direction of tops of beds indicated by the spatial relations of bedding and transverse cleavage corresponds to that indicated by graded bedding wherever both features are present.

Two large artificial cuts in Lower Devonian rocks along U.S. Route 201 are the only such exposures in the area, and both contain extensive folding and furnish evidence about the mode of deformation in the area. The detailed structure in these roadcuts would rarely, if ever, be seen in natural exposures in the quadrangle. 


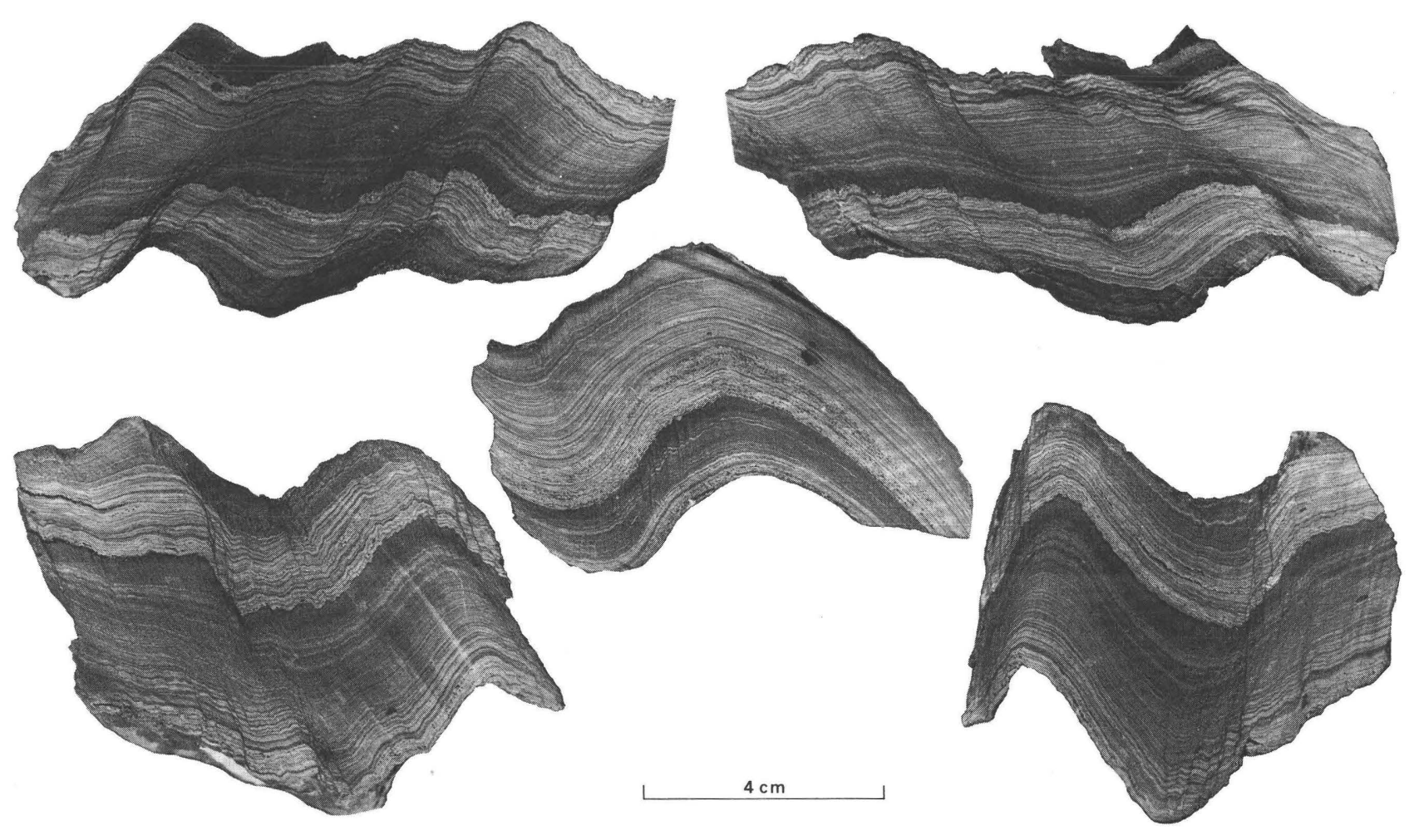

Figure 10.- Simall folds in the Frontenac Formation. The specimens are 1-inch-thick slabs cut from a single fold and illustrate variation along the fold axis as well as transition from transverse cleavage in the dark-gray argillaceous layers to concentric shear in the light-gray sandy layers. 

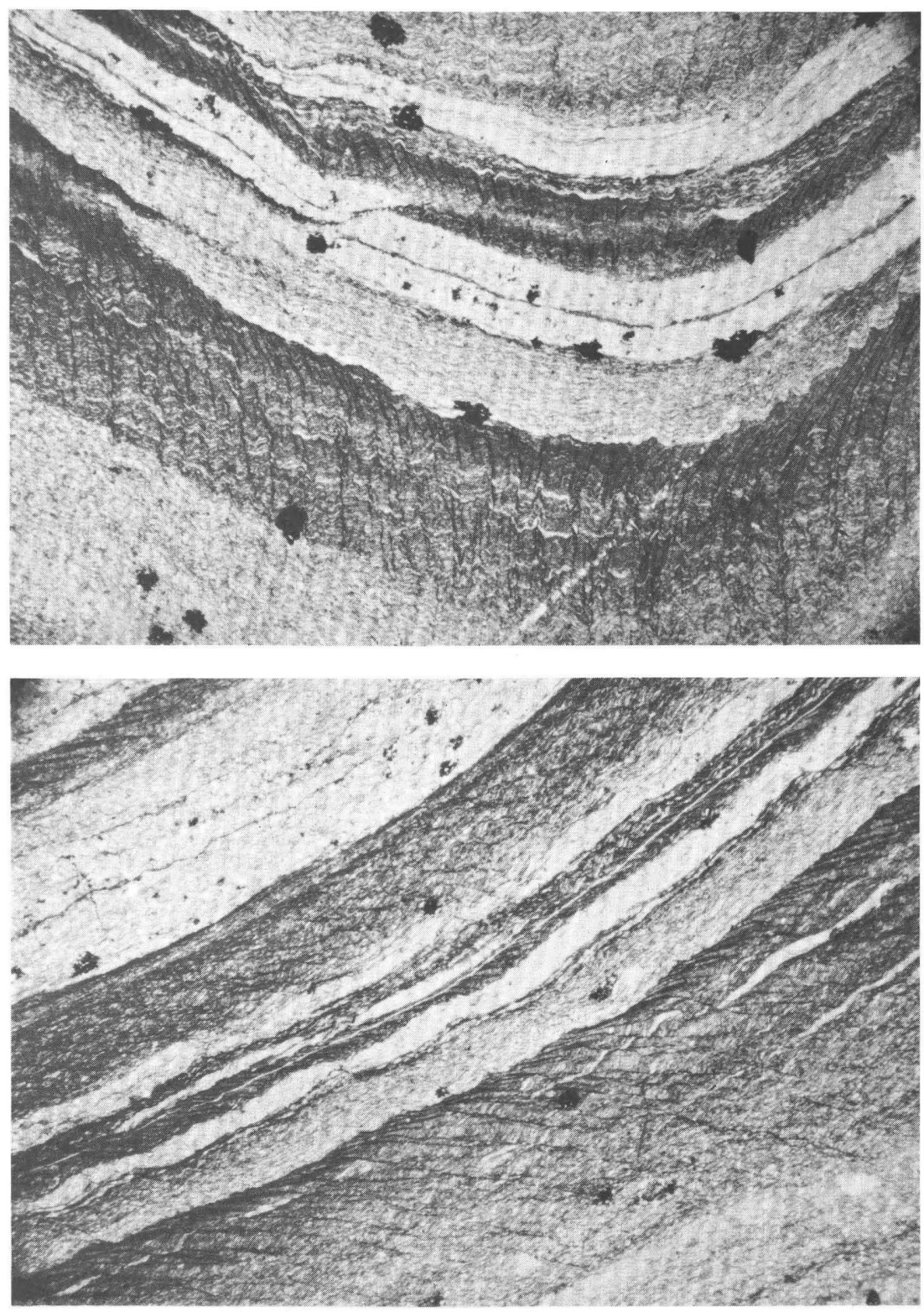

$3 \mathrm{~mm}$

FTgURE 11.-Photomicrographs showing relations between transverse cleavage and bedding in small folds in the Seboomook Formation. Transverse cleavage is closely spaced in the dark-gray argillaceous layers, is absent in the white sandy layers, and shows a transition in the graded beds giving way to bedding schistosity in the gray layers of intermediate composition. Plane-polarized light. 
Plate 3 is a sketch of a vertical section of a series of roadcuts along U.S. Route 201 at the north border of the Attean quadrangle in the Frontenac Formation. Cleavage-bedding relations, refracted cleavage, graded bedding, and observed crests and troughs of folds indicate at least 13 reversals of the direction of tops of beds in this 720-foot section. The natural outcrops above the cut do not show any such detail. The spacing of the transverse cleavage is indicated schematically on the sketch and corresponds to the generalizations above. Finegrained hornblende diorite at 120-160 feet on the sketch is not cleaved, but it is fractured and schistose near the contacts. More quartzose rock at 160-210 feet has rather widely spaced cleavage, nearly parallel to bedding. Argillaceous sandstone at 235-255 feet also has rather widely spaced transverse cleavage and contains concretions flattened in the plane of the cleavage and elongated down dip. The more closely spaced transverse cleavage is refracted by lithologic differences and fans through axial regions of folds. However, the curvature of the cleavage at $300-310$ feet is probably the result of later deformation rather than refraction.

The second artificial cut is within the Seboomook Formation and is about 700 feet long; it is along the stream where the East Branch of Sandy Stream has been relocated during highway construction (NE-1.8, 3.9). In this outcrop, nine reversals of tops of beds are indicated by cleavage-bedding relations and crests or troughs of folds. Throughout the section the transverse cleavage strikes about N. $65^{\circ} \mathrm{E}$. and dips $27^{\circ}-57^{\circ} \mathrm{N}$. Bedding dips north and south, changing in dip through both the vertical and the horizontal in different folds. In most of the section, however, the bedding dips north and the cleavage dips either more steeply or less steeply north depending upon the direction of tops of beds. The cleavage is deformed by fold-band sets that are spaced 0.5 inch to 2 feet apart, strike about N. $70^{\circ} \mathrm{W}$., and dip about $65^{\circ} \mathrm{S}$. Concretions in this cut are also flattened in the plane of the cleavage.

The folds in both cuts are similar in most aspects. Axial planes are steeply inclined to the north, and the hinge is very sharp. The hinge is sharper in the slate than in argillaceous sandstone where the two can be observed, but commonly the hinge cannot be seen in slate at all because of breakage and disjunctive dislocation at the crest. Many of the folds have one limb cut off by steeply dipping faults, apparently nearly parallel to the strike of bedding. Individual beds are thicker on the hinge than on the flanks.

An estimated one-third of our field stations in the Devonian rocks provided data, either graded bedding or cleavage-bedding relations, on the direction of tops of beds; nearly all these indicated tops of beds were to the north. Taken at face value, the structural symbols on plate 
1 and the increased outcrop breadth from west to east would suggest that the Seboomook Formation thickens greatly from west to east. Much of this increase in outcrop breadth is believed to be due to repetition by many nonsystematic folds rather than by well-defined folds whose axial region might be located and indicated on a map. The upward extension parallel to the cleavage must also increase the outcrop breadth.

Our observations, particularly those on small folds, indicate that concentric folding and cleavage folding (shear folding) occurred together, but observations in the two artificial cuts suggest that cleavage folding was more important. The necessary upward extension parallel to cleavage is confirmed by the down-dip elongation of concretions flattened in the plane of the cleavage, by observed offsets of bedding, and by the form of the crinkles in the slices between cleavage planes. It is inferred that the typical slate of the Seboomook Formation contains many such folds, that the spacing of transverse cleavage differs and may make recognition of hinges difficult, and that actual offsets or faults on fold limbs, such as those seen in the cuts, may be abundant. Such deformation would tend to bring a unit down into the plane of the map over a greater outcrop breadth than would be produced by an undeformed monoclinal section. This deformation could have produced the great outcrop breadth, relative to the observed dips and assumed thickness, of the Seboomook Formation on the east side of the Attean quadrangle.

This mode of deformation is believed to explain our bias in recording north-facing tops of beds more often than south-facing tops. Two considerations are important here: First, the asymmetry of folds with northward-dipping axial planes has produced a geometry such that bedding and cleavage dips are seldom the same on northfacing limbs, but tend to coincide on the south-facing limbs; second, south-facing limbs contains the disjunctive elements produced by folds passing into faults by thrust movement. In the first consideration, tops are rather easily determined by the criterion of beddingcleavage intersection, and graded bedding is better preserved. In the second consideration, the south-facing limbs were probably more susceptible to glacial erosion because leeward-slope plucking was facilitated by brecciation and partial comminution of the rocks in these limbs.

\section{STRUCTURAL SYNTHESIS}

The deformation which formed the broad open warps of the Boundary Mountain anticlinorium and the Frontenac synclinorium expressed itself very differently within the individual lithologic units. The pre-Upper Silurian rocks deformed by fracturing and shearing, whereas the Upper Silurian and Lower Devonian argillaceous rocks 
deformed by flattening and upward etxension in the plane of the transverse cleavage and by local tight folding. The more massive Silurian limestone and Silurian-Devonian sandstone bear rather slight evidence of deformation, although the Upper Silurian conglomerate unit has joint patterns much like those in the Attean Quartz Monzonite (Ordovician (?)).

The older rocks may have behaved somewhat as a buttress-a rather rigid block-during the deformation which produced the folds and cleavage in the younger rocks. The pre-Upper Silurian rocks merely fractured during this deformation, and well-formed joint sets in the Attean Quartz Monzonite resulted. Local intensive shearing is indicated by the cataclasis described in an earlier section; formation of the shearing was more dependent upon structural position than upon the amount of alteration.

Shearing is not formed near the contact in the vicinity of Sally Mountain, where the quartz monzonite is only slightly altered, or in the vicinity of Sugar Berth Pond, where the quartz monzonite is highly altered. The contact at Sugar Berth Pond is at a large angle to the cleavage in the overlying younger rocks. The distinct cataclastic zone near the contact in the Turner Pond area may have formed as the result of differential movement at the contact between rocks deforming rather plastically and rocks deforming rather brittly. The difference in the formation of schistosity between the northwestern part of the area and the area near Sally Mountain would be expected because of their positions within the Boundary Mountain anticlinorium-one on the limb and one on the axial region, respectively.

Such an interpretation requires that the Upper Silurian and Lower Devonian rocks moved over the pre-Upper Silurian rocks during the deformation. Low-angle strike faults in the younger rocks are not anywhere obvious, but several lineaments expressed on the aerial photographs along the projection of the cataclastic zone from the Attean Quartz Monzonite into the Seboomook Formation (pl. 1) may be erosional expressions of such faults. Several lineaments occur in the cataclastic zone west of the North Branch of Wood Stream, and it is believed that the cataclastic zone expresses a décollement produced by thrust transport of the Seboomook and Frontenac Formations southeasterly over the pre-Upper Silurian rock buttress, although no such décollement is illustrated on the bedrock geologic map (pl. 1). Wood stream has largely imposed itself upon this fault zone, producing the regional lineament. The thrust extends to the southwest, probably coincident with structural features recently mapped in the Arnold Pond quadrangle (3-C, fig. 2) by D. S. Harwood (unpub. data, 1967). The cataclastic zone in the Attean Quartz Monzonite probably persists to the northeast, as well as to the southwest, beneath the cover of the metasedimentary rocks. 


\section{METAMORPHISM}

Rocks of Early Devonian and older age in the Attean quadrangle have undergone low-grade metamorphism which is clearly post-Early Devonian in age. Potassium-argon age determinations (see section on radioactive ages) indicate that this metamorphism occurred 360 m.y. ago in late Early or Middle Devonian time ; slightly later, the contactmetamorphic aureole around the Hog Island stock was formed. The contrast in metamorphic grade and texture between the pre-Upper Silurian granofels unit and the overlying Upper Silurian rocks indicates that the granofels was metamorphosed to a higher grade prior to the deposition of the Upper Silurian rocks. Two different metamorphic episodes are therefore indicated; the earliest is probably associated with the Taconic orogeny if the age assignment of the granofels unit is correct, and the latest is associated with the Acadian orogeny.

\section{PRE-UPPER SILURIAN ROCKS}

The granofels unit was probably metamorphosed as high as sillimanite grade before Late Silurian time; subsequently, the unit was altered (retrograde metamorphism) during the chlorite-grade metamorphism associated with the Acadian orogeny. The earlier metamorphism is indicated by:

1. Relict sillimanite, garnet, and biotite, highly altered to assemblages characteristic of chlorite-zone metamorphism, occur in the granofels unit. These diagnostic minerals are absent in the Upper Silurian and Lower Devonian rocks. Plagioclase in the granofels is more calcic than is normal in chlorite-zone metamorphism, and it has also been highly altered by the later metamorphism.

It was inferred that the high plagioclase content of the granofels unit was due to abundant volcanic detritus and that the mafic lithic fragments are of volcanic origin. However, none of the lithic fragments have volcanic textures or mineralogy, and most fragments consist of hornblende and plagioclase. These features are compatible with a volcanic origin only if they were metamorphosed to a higher grade than that of the Acadian orogeny. Moreover, some of the granofels of probable sedimentary origin contains hornblende.

2. Granulation, intense suturing of grain contacts, and undulatory extinction of quartz in the granofels preceded the later alteration of plagioclase.

These features suggest that extensive deformation, tentatively correlated with the Taconic orogeny, occurred prior to the alteration related to the Acadian orogeny. 
The time of intrusion of the pre-Upper Silurian diorite relative to the earlier metamorphism is not clear. The mineral assemblage of the diorite, predominantly hornblende and plagioclase, could form either by crystallization from a silicate melt or by metamorphism of mafic rocks at a grade compatible with the presence of sillimanite and hornblende in the granofels. Crosscutting relations indicate that the Attean Quartz Monzonite is younger than the diorite, and no evidence has been found to suggest that the quartz monzonite was affected by the earlier metamorphism. We infer that the diorite correlates with that mapped recently by Boudette in the Chain Lakes quadrangle (4-C, fig. 2), which intrudes rocks of Middle Ordovician or older age. Our conclusion, on the basis of these relationships, is that the diorite, and then the Attean Quartz Monzonite, were emplaced later than, or during late stages of, the earlier metamorphism.

There is no evidence, however, that this earlier metamorphism had a simple spacial relationship either to the diorite or to the Attean Quartz Monzonite. Moreover, the intrusion of a pluton, such as the Attean Quartz Monzonite, and an orogenic event producing regional metamorphism are not necessarily a coupled process. The intrusion of the Attean pluton is not, therefore, documentation of Taconic metamorphism in the Attean quadrangle.

The later retrograde metamorphism of the pre-Upper Silurian rocks has obscured the character of the earlier metamorphism. Also, whether structural deformation accompanied the earlier metamorphism in the granofels unit is unclear, for the record is obscured due to lack of layering. Transverse relationships of well-layered pre-Upper Silurian units with the younger rocks near the south end of the Moose River synclinorium suggest that the deformation, at least for them, was of major proportions (Albee, 1961). If our inference that the granofels is correlative with these well-bedded pre-Upper Silurian units is correct, then the deformation was probably comparable.

\section{UPPER SILURIAN AND DEVONIAN ROCKS}

The Devonian hornblende diorite and the Upper Silurian and Lower Devonian sedimentary rocks have been affected by the regional metamorphism associated with the Acadian orogeny. This metamorphism only reached chlorite grade in this area. The argillaceous and arenaceous rocks contain muscovite and chlorite; they do not contain biotite or other higher grade minerals, nor do they contain clay minerals that might have been present in the original sediment. The hornblende and plagioclase in the hornblende diorite have been partly altered to mineral assemblages characteristic of chlorite-zone metamorphism. 
The contact-metamorphic aureole around the Hog Island Granodiorite is generally less than a mile wide. This contact metamorphism was only of middle grade, as indicated by the assemblages cordieritebiotite-chlorite-white mica-quartz in the argillaceous rock of the Seboomook Formation and diopside-grossularite-quartz-feldspar-calcite in the Upper Silurian conglomerate unit. Biotite in the Attean Quartz Monzonite within the aureole was recrystallized. The actual granodiorite contact is knife sharp and contains no mineral zones. The sharpness of the contact suggests that no exchange of material, with the possible exception of water and other volatiles, occurred across it.

The contact metamorphism is inferred to have postdated the thermal peak of the Middle Devonian regional metamorphism. No diaphthoresis of the minerals crystallized during contact metamorphism is evident; therefore, we can only be certain that the contact aureole was impressed upon the rocks surrounding the Hog Island pluton either at the thermal peak of regional metamorphism, or later, and that no opportunity was afforded the contact rocks to equilibrate thermally with their outlying counterparts. Additional evidence to suggest latekinematic or postkinematic intrusion is summarized in the section on radiometric ages.

\section{RADIOMETRIC AGE DETERMINATIONS}

Isotopic or lead-alpha age determinations have been made on metamorphic or igneous minerals from several units in the Attean, Long Pond, and Spencer Lake quadrangles. Measurements have been made on the following samples: (1) biotite and zircon from the Hog Island Granodiorite (post-Oriskany) (2) muscovite and biotite from the contact-metamorphic aureole of the granodiorite, (3) muscovite from the Seboomook Formation (Lower Devonian), (4) biotite and zircon from the Attean Quartz Monzonite (Ordovician (?)), and (5) biotite from the pre-Upper Silurian granofels unit.

The potassium-argon and rubidium-strontium age determinations on rocks from the Attean quadrangle (Hurley and others, 1959; Faul and others, 1963), are given in table 12. These include measurements by two laboratories on different parts of samples from the Hog Island Granodiorite and the Attean Quartz Monzonite, samples from the Seboomook Formation, and samples from the contact-metamorphic aureole around the Hog Island stock. All the samples, including those of the pre-Upper Silurian rocks, gave potassium-argon ages close to 360 m.y. Ages of 353 and 325 m.y. have also been reported (Hurley and others, 1958, p. 39) on biotite in two samples of the granofels unit from the northern part of the Spencer Lake quadrangle. 
TABLE 12.-Potassium-argon and rubidium-strontium age determinations from the Attean and Long Pond quadrangles, Maine

[Samples with prefix $\mathbf{B}$ are biotites and those with prefix $\mathbf{R}$ are whole rocks analyzed at Massachusetts Institute of Technology; those with prefix Me are biotites analyzed by the U.S. Geological Survey. Ages are calculated on the basis of $\lambda_{c}=585 \times 10^{-10} \mathrm{yr}^{-1} \lambda_{\theta}$ (M.I.T. samples) $=5.30 \times 10^{-10} \mathrm{yr}^{-1}$ for $\mathrm{K}^{40} ; \lambda_{B}$ (USGS samples $)=4.72 \times 10^{-10} \mathrm{yr}^{-1}$ for $\mathrm{K}^{40} ; \mathrm{K}^{10}=1.22 \times 10^{-4} \mathrm{~g} / \mathrm{gK}$; and $\lambda_{\beta}=1.39 \times 10^{-11} \mathrm{yr}^{-1}$ for $\mathrm{Rb}^{87}$. Potassium analyses were made with a Perkin-Elmer flame photometer using a lithium internal standard. Argon analyses were made by isotope dilution techniques]

\begin{tabular}{|c|c|c|c|c|c|c|c|}
\hline \multirow[b]{2}{*}{ Sample } & \multirow[b]{2}{*}{ Field No. } & \multirow[b]{2}{*}{ Location 1} & \multirow[b]{2}{*}{ Rock unit } & \multicolumn{3}{|c|}{ Potassium-argon determinations } & \multirow{2}{*}{$\begin{array}{c}\text { Age } \\
\text { (million } \\
\text { years) }\end{array}$} \\
\hline & & & & $\underset{\text { (percent) }}{\mathbf{K}}$ & $\mathrm{Ar}^{40} / \mathrm{K}^{\mathbf{1 0}}$ & $\begin{array}{l}\text { Air cor- } \\
\text { rection } \\
\text { (percent) }\end{array}$ & \\
\hline \multirow[t]{2}{*}{ B-3609... } & BB-2525a.. & $\mathrm{EC}-2.55,2.75$ & $\begin{array}{l}\text { Hog Island } \\
\text { Granodiorite. }\end{array}$ & $\begin{array}{l}5.49 \\
5.59 \\
5.56 \\
5.49\end{array}$ & $\begin{array}{r}0.0231 \\
.0239 \\
.0233\end{array}$ & $\begin{array}{l}16.0 \\
5.5 \\
0\end{array}$ & $\begin{array}{l}360 \pm 17 \\
370 \pm 17 \\
362 \pm 15\end{array}$ \\
\hline & & & & 25.53 & & & $2364 \pm 10$ \\
\hline $\begin{array}{l}\mathrm{Me}-10 \ldots \\
\mathrm{B}-3593 .\end{array}$ & $\begin{array}{l}\text { BA-215 } \\
\text { BB-2526b. }\end{array}$ & $\mathrm{SE}-1.17,4.49$ & Attean Quartz & $\begin{array}{l}7.01 \\
3.74\end{array}$ & $\begin{array}{l}.0283 \\
.0229\end{array}$ & $\begin{array}{l}4.3 \\
3.2\end{array}$ & $\begin{array}{l}360 \pm 10 \\
356 \pm 15\end{array}$ \\
\hline $\begin{array}{r}M e-9 a \\
-9 b^{3}=\ldots\end{array}$ & BA-766-... & - . do do & do do & $\begin{array}{l}4.41 \\
4.01\end{array}$ & $\begin{array}{l}.0299 \\
.0294\end{array}$ & $\begin{array}{l}18 \\
32\end{array}$ & $\begin{array}{l}366 \pm 10 \\
373 \pm 10\end{array}$ \\
\hline \multirow[t]{2}{*}{ R-3444 } & n & SC-1.7, 3.9, & $\begin{array}{l}\text { Seboomook } \\
\text { Formation. }\end{array}$ & $\begin{array}{l}3.29 \\
3.26 \\
\end{array}$ & & $\ldots$ & \\
\hline & & & & 23.27 & .0238 & 1.8 & $4368 \pm 15$ \\
\hline \multirow[t]{2}{*}{ R-3447 . } & (n) & $\mathrm{NE}-2.2,2.0$ & ................ & $\begin{array}{l}2.61 \\
2.71\end{array}$ & $\ldots$ & $\ldots$ & ............ \\
\hline & & & & 22.66 & .0244 & 12 & $1377 \pm 18$ \\
\hline \multirow[t]{2}{*}{ R-3448. . . } & ......... & $\begin{array}{l}\text { C-1.5, 2.6, Long } \\
\text { Pond quad. }\end{array}$ & $\ldots$. do & $\begin{array}{l}2.57 \\
2.57\end{array}$ & $\ldots$ & $\ldots$ & (n.......... \\
\hline & & & & 22.57 & .0224 & 12 & $4350 \pm 15$ \\
\hline \multirow[t]{2}{*}{ R-3883. } & BA-1108_. & $\begin{array}{l}\text { Block, east } \\
\text { shore of Wood }\end{array}$ & $\begin{array}{l}\text { Fossiliferous cor- } \\
\text { dierite hornfels }\end{array}$ & $\begin{array}{l}2.84 \\
2.86\end{array}$ & $\ldots$ & $\ldots$ & .......... \\
\hline & & & Formation. & 22.85 & .0243 & 0 & $1365 \pm 10$ \\
\hline
\end{tabular}

$\frac{\mathrm{Sr}_{(\mathrm{ppm})}^{\mathrm{Sr}} \underset{(\mathrm{ppm})}{\mathrm{Rb}} \stackrel{\mathrm{Sr}}{(\mathrm{ppm})}^{87} \mathrm{Sr}^{87} / \mathrm{Rb}^{87}}{\begin{array}{c}\text { Rubidium-strontium } \\ \text { determinations }\end{array}}$

\begin{tabular}{|c|c|c|c|c|c|c|c|c|}
\hline B-3609A & $\underset{\text { BA-215 }}{\text { BB-2525a, }}$ & EC-2.55, 2.75 & $\begin{array}{l}\text { Hog Island Gran- } \\
\text { odiorite. }\end{array}$ & 46.1 & 472 & 0.720 & 0.00538 & $360 \pm 28$ \\
\hline
\end{tabular}

\footnotetext{
1 Explanation given in description of fieldwork.

2 Average.

3 Separate biotite concentrates.

- Calculated from averaged data.
}

Age measurements by Lyons and others (1957, table 5), using the lead-alpha method on zircons from granitic rocks in this area, gave somewhat younger values. Two of these measurements (320 m.y., 316 m.y.) were on the Katahdin Quartz Monzonite (Katahdin Granite of many authors), which is also post-Oriskany in age (Boucot, 1954). Three of the measurements (330, 302, and 322 m.y.) were made on samples originally thought to be the Hog Island Granodiorite, 
but which are now known to be from an area within the Attean Quartz Monzonite. New measurements on zircon from these rocks by the use of an improved technique for the determination of lead (Rose and Stern, 1960; Stern and Rose, 1961), are given in table 13. The samples include one (table 13, BB-2526e) collected at the locality of the Lyons sample, duplicates of those used for the potassium-argon and rubidium-strontium ages, and several other samples of the Hog Island Granodiorite and Attean Quartz Monzonite.

TABLE 13.-Lead-alpha age determinations on zircon from the Attean Quartz Monzonite and Hog Island Granodiorite in the Attean and Long Pond quadrangles, Maine

[The lead-alpha ages were calculated from the equations $t=C(\mathrm{Ph} / \alpha)$ and $T=t-1 / 2 k t^{2}$, where $t$ is the calculated age in millions of years; $C$ is a constant based upon the $T h: U$ value; $P b$ is the lead content in parts per million; $\alpha$ is the alpha counts per milligram per hour; $T$ is the age in millions of years, corrected for the decay of uranium and thorium; and $k$ is a decay constant based on the $T h: U$ ratio. Lead content was determined by N. B. Sheffey, H. J. Rose, Jr., and T. W. Stern; all values are averages of duplicate determinations. Measured Th: U values were determined by X-ray fluorescence analysis; $\mathbf{F}$. J. Flanagan, analyst]

Field No. Location 1 $\quad \alpha \quad \begin{gathered}\mathrm{Pb} \\ \text { (ppm) }\end{gathered}$

Hog Island Granodiorite

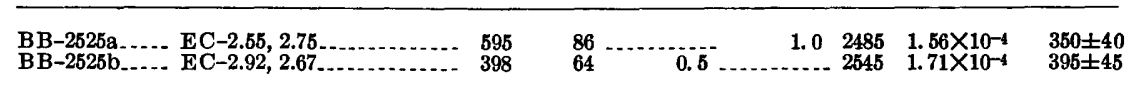

Attean Quartz Monzonite

\begin{tabular}{|c|c|c|c|c|c|c|c|}
\hline $\begin{array}{l}\text { BB-2526a } \ldots . . \text { SC-3.14, 1.94 } \\
\text { BB-2526b. } \\
\text { BB-2526c } \ldots \text { SE-1.17, 4.49 } \\
\text { BB-2526d. } \\
\text { BB-2526e. }\end{array}$ & $\begin{array}{l}157 \\
246 \\
222 \\
306 \\
284\end{array}$ & $\begin{array}{l}30 \\
52 \\
42 \\
50 \\
52\end{array}$ & 1.0 & 1.0 & $\begin{array}{l}2485 \\
2485 \\
2485 \\
2485 \\
2485\end{array}$ & $\begin{array}{l}\text { 1. } 56 \times 10^{-4} \\
\text { 1. } 56 \times 10^{-4} \\
\text { 1. } 56 \times 10^{-4} \\
\text { 1. } 56 \times 10^{-4} \\
\text { 1. } 56 \times 10^{-4}\end{array}$ & $\begin{array}{l}455 \pm 50 \\
500 \pm 60 \\
460 \pm 50 \\
395 \pm 45 \\
435 \pm 50\end{array}$ \\
\hline
\end{tabular}

1 Explanation given in description of fieldwork.

Comparison of the radiometric ages for the Seboomook Formation and the Hog Island Granodiorite suggests that the regional metamorphism and the intrusion occurred nearly simultaneously or that the biotite of the intrusive rock did not become a closed system until the metamorphism waned. The coarseness and the systematic orientation of the muscovite and chlorite in the slate indicate that these minerals are entirely of metamorphic origin. We are confident that detrital and diagenetic potassium-bearing minerals do not remain in sufficient quantity to affect the measurements of the age of the metamorphic minerals. Furthermore, because potassium feldspar was not observed and plagioclase feldspar is not abundant, virtually all the potassium in the slate can be assigned to the muscovite.

The alteration of the Attean Quartz Monzonite has been described in an earlier section. Although primary biotite was probably present in part of the rock, most of the biotite now present in the rock is 
pseudomorphic after hornblende. The fact that this biotite has the same age as the regionally metamorphosed slate suggests that the alteration of the Attean Quartz Monzonite was related to the postEarly Devonian metamorphism. Similarly, although the granofels unit contains relict sillimanite and garnet related to an earlier metamorphism, biotite from two samples of the granofels (Hurley and others, 1958, p. 39) gave ages that indicate the biotite formed during the post-Early Devonian metamorphism.

The radiometric ages suggest that the regional metamorphism and the intrusion of the Hog Island Granodiorite occurred nearly simultaneously. In the Attean Quartz Monzonite, however, the biotite that formed during the post-Early Devonian regional metamorphism has been recrystallized in the contact aureole of the Hog Island stock (see p. 66); this mineral transformation indicates that the intrusion must have occurred after the peak of the regional metamorphism.

Potassium-argon and rubidium-strontium ages for the Attean Quartz Monzonite do not reflect the age of its intrusion. Although not definitive, the lead-alpha ages for the Attean Quartz Monzonite are older than those for the Hog Island Granodiorite and the zircons may therefore give the true age of intrusion. Taken at face value, the radiometric ages for the Attean Quartz Monzonite indicate that it is of Cambrian or Ordovician age and not of Precambrian age. These ages support the tentative correlation of the Attean with the Highlandcroft Plutonic Series of northern New Hampshire (Billings, 1956, p. 46). Isotopic lead-alpha age measurements are necessary for both the Highlandcroft and the Attean Quartz Monzonite to definitely establish this correlation because of possible uncertainties inherent in the lead-alpha method.

From these age determinations it is concluded that the age of the Hog Island Grandodiorite and the time of the latest metamorphism is at least $360 \mathrm{~m} . \mathrm{y}$. Therefore, the Oriskany-age sedimentation took place prior to this time. This conclusion agrees with the findings of Fairbairn, Hurley, Pinson, and Cormier (1960) in Nova Scotia, where sedimentary rocks of similar age have been intruded by granitic rocks near Nictauw. Similar ages, ranging from 320 to 380 m.y., have been reported for the latest major metamorphic event all along the Appalachians. Comparison with potassium-argon ages of $385 \pm 15$ m.y. for Oriskany-age bentonite beds in Gaspé (Smith and others, 1961) suggests that the regional metamorphism was of late Early or Middle Devonian age, as has been established elsewhere in the Northern Appalachians on stratigraphic evidence. 


\section{QUATERNARY GEOLOGY}

\section{SURFICIAL DEPOSITS}

Much of the Attean quadrangle is covered by unconsolidated deposits that are products of continental glaciation, stream action, or the filling of lakes or ponds. These deposits include four main types: (1) unstratified deposits left by the ice as it passed over the area (till), (2) stratified deposits laid down by melt water during the wasting away of the ice (outwash sand and gravel, ice-channel fillings), (3) alluvial deposits of material reworked by streams since the disappearance of the ice (alluvium), and (4) deposits formed by the filling of ponds or lakes (swamp deposits).

The distribution of these deposits and the distribution of known bedrock outcrops are shown on the surficial geologic map (pl. 4). No attempt was made to map these unconsolidated deposits in detail; areal distributions and contacts are based upon incidental observations made during the course of mapping the bedrock geology and upon interpretation of the 1942 and 1958 aerial photographs. Neither natural nor artificial exposures of the surficial deposits are common in this area. For this reason, form was used more than lithology in locating contacts between the map. units.

About 80 percent of the surface of the Attean quadrangle is covered by a blanket of till ranging in thickness from a few inches to at least several tens of feet. Till cover is thinnest on the crests and upper slopes of ridges and thickest on the lower slopes and in the valleys. The amount of till underlying areas of alluvium and of outwash sand and gravel is not known.

The till is generally unstratified and unsorted; it is composed of angular rock fragments which have an extreme range in size. Although foreign fragments are common, most of the fragments in the till are like the underlying bedrock. In the northern part of the area overlying the slate, the matrix of the till contains a high proportion of smaller sized fragments; larger fragments are less abundant and smaller than in other parts of the area and are predominantly angular fragments of the underlying rock.

Till containing many very large boulders is abundant in the southeastern part of the area overlying the Attean Quartz Monzonite. The areal extent of this bouldery ti'l is indicated on the surficial geologic man. The large boulders in this till are Attean Quartz Monzonite, and they are set in a sandy quartz-feldspar matrix. The area underlain by the bouldery till has a hummocky topography dominated by ridges that seem to be composed largely of boulders. In these ridges, boulders 15-25 feet in diameter are rather abundant; some are as much 
as 60 feet in diameter. The islands in Attean Pond and the small ridges east and south of Attean Pond are good examples of such ridges.

Extensive boulder fields in which large boulders of the Attean Quartz Monzonite are piled against one another without much interstitial material occur in many places within the area of bouldery till. Most of these boulder concentrations were probably formed by removal of the finer grained interstitial fragments from the bouldery till, but some of them may have formed by frost wedging and breaking up of ledges of extensively jointed quartz monzonite. Many of the boulder fields occur around Attean Pond at altitudes just below 1,200 feet. The present seasonal variation in the level of Attean Pond is about 10 feet, and the bouldery shoreline between the high- and low-water levels is similar to the boulder fie'ds. Many of the boulder fields therefore probably represent ancient shore features of Attean Pond when its level was somewhat higher than at the present time. The present level of Attean Pond is maintained by a natural dam buttressed by boulders, and this dam was very likely higher in the past. Other boulder fields may represent stream channels or merely reworking of the bouldery till by melt water during the melting of the glacier. A boulder field just south of the Attean quadrangle (Spencer Lake quadrangle, NE-2.1, 5.5) seems to be on the extension of the ice-channel deposits shown in the southeastern part of the surficial geologic map (pl. 4).

Several areas of thick till have been distinguished on the map. These are areas in which very few bedrock outcrops were found, even in gullies and stream channels. The thick till in the areas south of Jackman, near the site of Stetson School, and south of Little Turner Pond seem to be plastered on the northwestern (up-current) side of bedrock ridges. The thick till between Little Big Wood Pond and Wood Pond does not bear this relation to a bedrock ridge, but it does possess a distinct form which is thought to represent a constructional till form closely akin to drumlins. The north slopes of Sally Mountain, the higher summit of Attean Mountain, and the mountain north of No. 5 Mountain are smooth slopes which have far fewer outcrops than the south slopes; these may also be constructional till features. The knolls east and northeast of Boulder Pond (SE-0.5, 0.75) and the large knoll northeast of Bog Pond (SE-1.5, 2.9) have many boulders on their surfaces, but may also fall in the same category. Drilled water wells along U.S. Route 201 between Moose River and Stetson School are reported by land owners to have penetrated as much as 90 feet of till before the bedrock surface was encountered. We regard this thickness to be an average maximum.

Several areas of outwash sand and gravel are shown on the map. 438-197-72-7 
The largest of these, in the Moose River valley near Jackman, extends northwest up the valley of the West Branch of Sandy Stream and east for some distance along the Moose River valley into the Long Pond quadrangle. Other areas of outwash deposits are near Holeb in the Moose River valley, near the junction of the North Branch of Wood Stream with Wood Stream, and in the upper valley of the East Branch of Sandy Stream. Similar material occurs just outside of the Attean quadrangle east of Coburn Pond (NE-3.5, 1.5). Most of these deposits are in valleys and have been modified by modern streams and partly covered by alluvium, but in such places the alluvium has not been shown separately on the map.

The deposits are composed of sorted well-bedded to poorly bedded sand and gravel containing some silt and clay. Those deposits in the Moose River valley near Jackman and Holeb are better sorted and stratified than those in other areas; crossbedding was seen in pits in each of these areas.

The hummocky and pitted surface of most of these deposits suggests that they accumulated in contact with wasting ice masses occupying valley bottoms. Though the gross form of the sand and gravel deposits in Sandy Stream below the junction of the East and West Branches suggests that they were deposited in narrow strips between the valley walls and residual bodies of wasting ice in the valley bottom, many of the present details of form are due to erosion and reworking of the deposits by the present stream. The planar surface of the deposits extending eastward from Jackman into the Long Pond quadrangle suggests that they accumulated beyond any stagnant ice.

Several elongate ridges of rudely sorted and stratified sand and gravel are shown on the surficial geologic map as ice-channel deposits. These ridges are clearly visible on the aerial photographs, and pits and cuts have been made in them at several places. These deposits are believed to mark deposition in ice-walled or subglacial channels.

Many areas of alluvium are shown on the surficial geologic map. These include the tree-covered parts of modern deltas and flood plains of recent streams and rivers. The largest area of alluvium is along the flood plain of the Moose River in the southern part of the quadrangle. The alluvial deposits are not well exposed, but probably consist mainly of sand, muck, and gravel.

Most of the alluvial deposits are in valley bottoms where the stream has a flat gradient above a knickpoint or dam of some sort. Many of these knickpoints are bedrock ledges or boulder piles; others are beaver dams which have become consolidated by vegetation, or manmade dams built mainly between 1910 and 1930 to store water for log drives. Most beaver dams and man-made dams, however, were built on 
preexisting natural knickpoints. Upstream from many of these knickpoints, meander scars and natural levees mark former channels of the stream. Such features are prominent on the flood plain of the Moose River above Holeb Falls, a bedrock knickpoint, and above Spencer Rips, a boulder-pile knickpoint. The aerial photographs show many more meander scars and levees than does the topographic map. Nearly all the streams have these same features on a smaller scale, and most of the alluvium in the area is found above such knickpoints.

The greater thickness of till on the lower slopes of ridges is probably due to local reworking of till by melt water. The basal parts of many of the alluvial deposits were probably formed at the same time and might be classed as outwash valley train deposits, in many respects similar to the outwash deposits along Sandy Stream.

Large alluvial deposits were formed as deltas at the inlets of Holeb Pond and Little Big Wood Pond, and smaller deltas occur on other lakes and ponds. These deltas, particularly the one in Holeb Pond, may also be in part glacial outwash.

The swamp deposits are in areas covered by swamp vegetation and are essentially devoid of trees. Such areas are clearly shown on the aerial photographs, and a rather sharp line of demarcation separates these areas from the tree-covered swampy areas (fig. 12). The areas shown as swamp deposits are underlain mainly by peat and muck and have a high water content; indeed, many of them are only unconsolidated rafts of vegetation on the edges of ponds.

Most of the areas of swamp deposits are ponds and lakes that have been filled or partly filled with muck, peat, clay, and sand. No. 5 Bog in the southeastern part of the quadrangle is the largest of these deposits. Curvilinear growth lines around Bog Pond (fig. 12) express the gradual encroachment of vegetation from the original shoreline. Some smaller ponds, such as those just east of Barrett Pond in the southwestern part of the surficial geologic map (pl. 4), have become completely filled by vegetation growth.

Several areas of artificial fill are shown on the surficial geologic map along the roadbed of the Canadian Pacific Railroad. Talus deposits have not been shown on the map, but small areas covered by talus blocks occur on many steep slopes below cliffs.

Materials from sand and gravel deposits are used locally for road and railroad fill and to surface roads. Materials for the statemaintained roads are derived mainly from the outwash deposits near Jackman. Most of the more extensive pits are located just east of the Attean quadrangle. A railroad siding has been built into the pits at Holeb, and sand and gravel from the outwash deposits there are used for railroad subgrade maintenance purposes. 


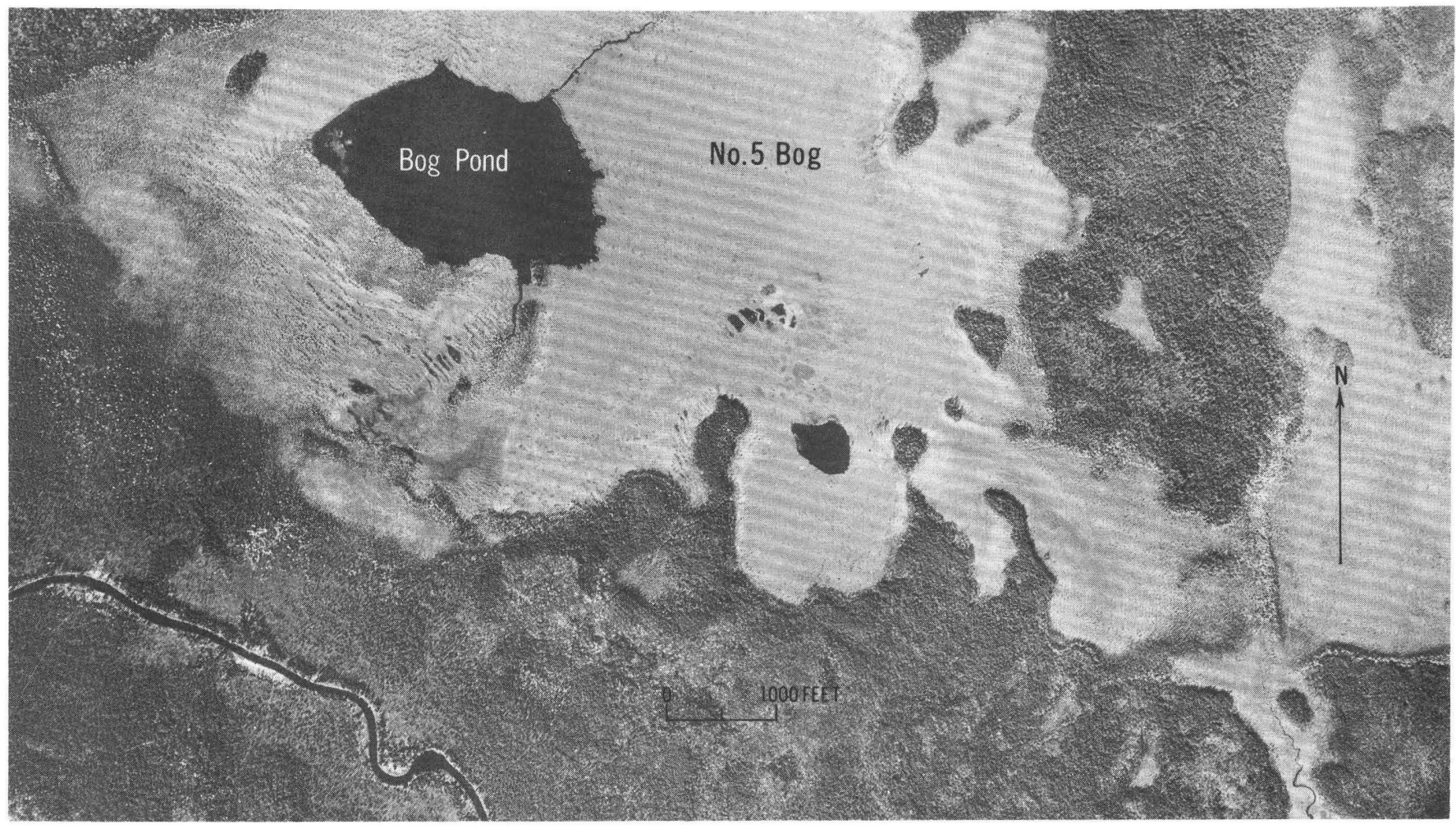

FIGURE 12.-Aerial photograph showing the vegetation contrast and surface appearance of an area underlain in part by bouldery till and in part by swamp deposits that have almost filled in a small pond, Bog Pond (pl. 4, SE.). 
Most of the lumber roads in this area are temporary bulldozed roads, which are filled and surfaced only where necessary to maintain travel over them. In the bouldery till area little filling or surfacing is needed and the roads remain serviceable for many years. In other areas, especially those overlying the slate, the till is so fine that a large amount of fill and a gravel surface is needed to maintain roads. In such areas unsurfaced bulldozed roads become deeply rutted by logging trucks and become unusable very quickly. Over such roads much of the log hauling is done when the ground is frozen, and roads which are to be used year round require surfacing. However, the till and even some of the outwash deposits in the upper part of Sandy Stream contain too much fine material to make satisfactory fill or surface material in swampy areas. Better sorted coarser gravel from the outwash deposits or from gravel bars in the stream alluvium has been used in that area.

Almost no agriculture is practiced in the area. Nearly all the few small farms and garden plots are on the outwash deposits near Jackman. Several rather large areas of cleared land along the highway north of Jackman are no longer farmed.

\section{PREGLACIAL TOPOGRAPHY AND EROSION BY ICE}

Although the main topographic features of the Attean quadrangle are presumably preglacial, they have been extensively modified by glaciation. Both glacial erosion and derangement of drainage by glacial deposits have been considerable.

Bedrock strongly influences the location of major topographic features. The area underlain by the slates of the Seboomook Formation has subdued topography and lower altitude than the areas underlain by the Frontenac and most of the pre-Upper Silurian rocks. In the areas underlain by the Seboomook and the Frontenac Formations, the major ridge pattern is determined by the dendritic pattern of the streams; each ridge, however, consists of a series of narrow crossridges (poorly expressed on the topographic map) parallel to cleavage and bedding. Crossridges formed by the diorites and sandstone beds in the Frontenac Formation show clearly on the aerial photographs. The preservation of these crossridges, which are oriented nearly normal to the direction of ice flow, suggests either that glacial erosion did not cut very deeply in that area or that contrasting erodibility of the interlayered rocks of the Frontenac favored differential glacial erosion, which etched the ridges into relief.

The low areas over the Attean Quartz Monzonite and Hog Island Granodiorite typify a common relationship in Maine where many granitic masses underlie lowlands, which are surrounded by a highland 
ring formed by the contact-metamorphosed aureole. Many such lowlands, as in this area, contain lakes formed by damming of outlets by glacial deposits or deepening of the basins by glacial erosion; however, the lowland itself probably existed before glaciation.

Many lakes and ponds are bounded by bedrock outcrops that bear glacial striae parallel to the long axis or straight shoreline of the lake, which suggests that these lakes were formed in part by glacial excavation of rock basins; the best examples are the west arm of Attean Pond and the southwest side of Wood Pond, but Holeb Pond, Mud Pond, Long Pond (Forsyth township), Crocker Pond, Benjamin Pond, and Horseshoe Pond also have these features. Figure 4 a shows the lakes and cliffs formed by glacial quarrying of well-jointed quartz monzonite in the vicinity of Benjamin Pond.

Most of the smaller streams have been deranged only slightly by glacial deposits, but the valley of Sandy Stream was well filled with outwash deposits, and outwash deposits are common in the Moose River valley. The generally smooth profile of Moose River suggests that features such as Holeb Falls did not exist in preglacial time, but no valley near Holeb Falls seems to be blocked with glacial deposits. The preglacial Moose River may have flowed from Holeb Pond into Attean Pond in a channel, now covered by glacial deposits, just south of the railroad tracks, but positive evidence for this route has not been found. The present levels of Attean Pond, Wood Pond, and Little Big Wood Pond are determined by till dams across their outlets.

\section{DIRECTION OF ICE FLOW}

Glacial striae and grooves in the Attean quadrangle trend generally east-southeast to southeast. Deviations in trend seem to have resulted from the local influence of topography on ice flow.

Flint (1951, p. 26-29; 1953, pl. 2) summarized some of the available data and suggested that a local ice cap or center of glacial outflow existed over this area both before and after the main ice sheet covered it. His argument is dependent upon evidence of northward ice flow in places north of the hypothetical ice cap, but nearly all recent workers in the Eastern Townships of Quebec have rejected the idea of northward ice flow (MacKay, 1921; McGerrigle, 1935; MacLean, in Dresser and Denis, 1944, p. 504-508; Béland, 1957, p. 29).

In the Attean quadrangle there is no evidence of northward or northeastward ice flow. A conspicuous boulder fan containing granodiorite and hornfels extends southeast from the Hog Island Granodiorite and clearly indicates the direction of the ice flow. Much glacial quarrying occurred in the area between Benjamin Pond and Holeb Pond, and many quarried blocks were carried away and dropped to 
form the bouldery till in the area south of Attean Pond. Erratics of the pre-Upper Silurian rocks are not found north of their outcrop area. Erratics of the fossiliferous rocks of the Moose River synclinorium, south and east of the Attean (mardrangle, were found far to the south (Perkins, 1934, p. 32), but none were seen in this area. A southeast-trending indicator fan, which crosses the drainage divide between the St. Lawrence and Kennebec Rivers, is composed of boulders from the granitic bodies near St. Sebastien de Beauce and the south end of Lake St. Francis, Quebec. Erratics derived from the Canadian Shield and erraties probably derived from sedimentary units near the St. Lawrence River have also been found in the area.

No typical cirque forms have been found in the Attean or nearby quadrangles, though suggestions of such forms can be seen on the Chain Lakes and Spencer Lake quadrangle maps. Local glaciers probably existed in the higher valleys during the adrance and recession of the major ice sheet, but it is not known whether these ever coalesced into a major center of glacial outflow.

\section{GEOLOGIC INTERPRETATION OF THE AEROMAGNETIC MAP}

Ba Jomn W. Allingham and Ampen It. Albee

An aeromagnetic survey of the Attean quadrangle proved a valuable supplement to the geologie mapping. Strong magnetic contrast between some geologic units produces the striking correlation between the aeromagnetic map (Bromery and Gilbert, 1962) and the bedrock geologic map (pl. 1). The aeromagnetic patterns outline large bodies of diorite, the Hog Island stock, large inclusions at the west border of the Attean Quartz Monzonite, and the area underlain by the granofels unit. Magnetic profiles along the flight lines were available during the third season of fieldwork. The aeromagnetic contour map, completed after the close of the geologic mapping, indicated several revisions in the geologic mapping, and several weeks were spent verifying these revisions. The locations of the buried contacts of the Hog Island stock and of the intrusire diorite in the southwest corner of the quadrangle were inferred in part from the aeromagnetic information.

The Attean quadrangle was aeromagnetically surveyed in 1957 by the U.S. Geological Survey (Bromery and (*ilbert, 1962) using a continnously recording fluxgate magnetometer installed in a twinengine aircraft. The flight lines were spaced a quarter of a mile apart at about 500 feet above the ground. Magnetic information in the northwest part of the quadrang? is from the aeromagnetic map of the Armstrong area, Quebec (Canada Geol. Survey, 1953). 
Measured magnetic susceptibilities and densities of rock samples from rock units in the Attean quadrangle are summarized in table 14. The susceptibility depends mainly on the amount of magnetite in the rock, but slightly magnetic minerals such as ilmenite and pyrrhotite also contribute to the magnetic susceptibility. In most samples the measured intensity of remanent magnetism was negligible or its mean direction was random. Several samples of pre-Upper Silurian granofels and diorite, however, had a high-intensity remanent magnetism directed opposite to that of the present magnetic field of the earth.

TABLE 14.-Magnetic susceptibilities and densities of rock units in the Attean quadrangle, Maine

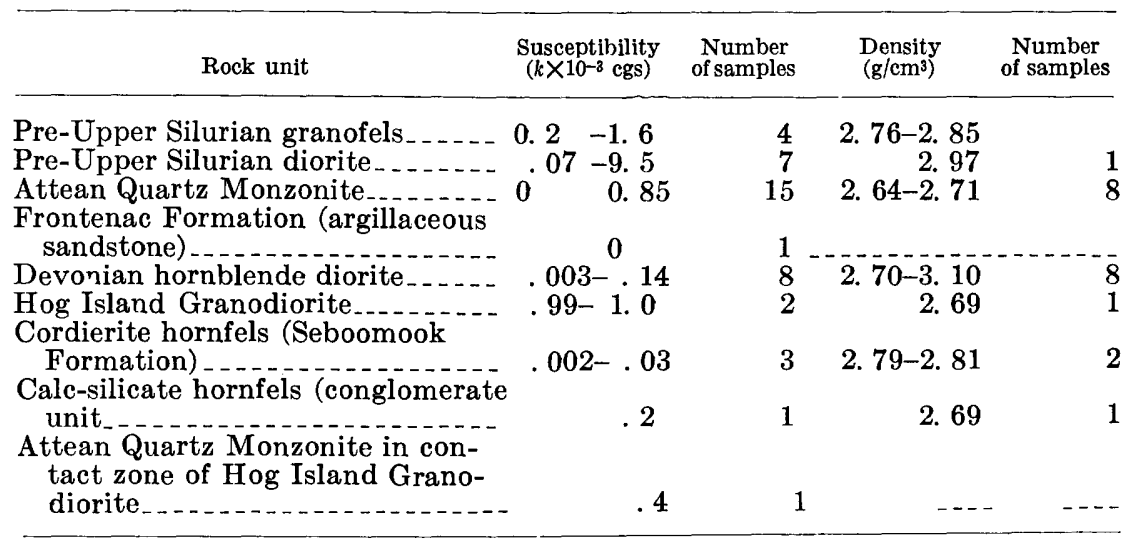

The measured susceptibilities of the rock units relative to one another correspond to what would be inferred from the aeromagnetic pattern. The pre-Upper Silurian rocks are generally more magnetic and denser than the Silurian and Devonian rocks; moreover, the pre-Upper Silurian rocks have a greater range in properties, and this range produces a more complex magnetic pattern. Thin sections of both the granofels and the diorite contain as much as 7 percent opaque minerals. In some samples these opaque minerals are closely associated with sphene, leucoxene, and rutile, suggesting that the opaque phase is ilmenite or titaniferous magnetite, but in others the mineral is clearly magnetite. A large positive anomaly is associated with the diorite in the southwest corner of the quadrangle. Although the measured sam-ples from this mass have low magnetic susceptibilities and contain ilmenite, it must be inferred from the high amplitude of the anomaly that most of the diorite contains magnetite. Samples of the Attean Quartz Monzonite have a narrow range of susceptibilities, which are generally lower than those for the granofels and diorite.

Within the Upper Silurian and Devonian rocks, only the Devonian hornblende diorite, the Hog Island Granodiorite, and some rocks 
of the associated contact-metamorphic aureole have significantly high susceptibilities. However, measured susceptibilities on the Devonian hornblende diorite are much too low in comparison with susceptibilities computed from the corresponding anomalies.

The Attean quadrangle can be divided roughly into two parts on the basis of aeromagnetic data: a northern part, predominantly underlain by Upper Silurian and Lower Devonian sedimentary rocks of negligible susceptibility; and a southern part, mainly underlain by pre-Upper Silurian intrusive and metasedimentary rocks of variable susceptibility. In the northern part the pattern merely reflects the regional magnetic gradient that increases about six gammas per mile northward. Small low-amplitude anomalies, which can be seen on the measured profiles (pl. 1) and which are associated with hornblende diorite sills and dikes, are superimposed on the regional magnetic gradient over the Frontenac Formation. In a general way, these low-amplitude anomalies distinguish the area underlain by the Frontenac from that underlain by the Seboomook.

A sharp positive anomaly of about 420 gammas is associated with the mass of Devonian hornblende diorite near Slidedown Mountain (NC-1.5, 4.3). The aeromagnetic pattern can be approximated by a model consisting of an infinite vertical cylinder, 3,000 feet in diameter, having a susceptibility contrast of $6.1 \times 10^{-3} \mathrm{cgs}$ (pl. 1, profile $C-C^{\prime}$ ). Although susceptibilities of eight samples of the hornblende diorite were measured, including two from this mass, the maximum measured value was only $0.14 \times 10^{-3} \mathrm{cgs}$. Moreover, the symmetry of the magnetic field demands a cylindrical body, whereas the hornblende diorite crops out in sills and dikes. Therefore, the magnetic anomaly probably is not directly related to the exposed hornblende diorite, but is related to a plug-shaped subsurface body of high susceptibility, which could have been the source of the many dikes and sills of hornblende diorite.

Aeromagnetic data in the Canadian part of the Attean quadrangle (Canada Geol. Survey, 1953) indicate a connection between the anomaly at Slidedown Mountain and the south-trending elongate 60to 100-gamma positive anomaly at the west side of the quadrangle. This anomaly extends through the area underlain by the Frontenac and Seboomook Formations and into areas underlain by the granofels unit and Attean Quartz Monzonite. Because its trend is nearly parallel to the original flight lines, this anomaly was confirmed by flights across its trend. The profile of the anomaly seems to infer that a dikelike magnetic unit having a width of about 1,000 feet might crop out at the surface; however, no rock unit corresponding to this anomaly could be located, though almost continuous outcrop exists across the anomalous area in several places. (See pl. 4.) For example, a traverse 
across a point where the anomaly is well formed (WC-1.3, 4.2) encountered nearly continuous exposure except for a 400-foot gap in the saddle between the two knobs shown on the topographic map. At several other points along the anomaly, outcrops rule out the existence of an exposed dike nearly 1,000 feet wide. Three traverses with a Hotchkiss Superdip were made across the anomaly northwest of Little Turner Pond. One traverse, made with stations at 200-foot intervals, detected no anomaly; another, with stations at 150 -foot intervals, located a 30-gamma positive anomaly less than 300 feet wide. A traverse across the saddle mentioned above, with stations 60 feet apart, detected a 40-gamma positive anomaly less than 340 feet wide. No outcrop of the magnetic rock unit could be found. The anomaly is apparently caused by a narrow magnetic body, probably a mafic dike, which does not crop out at the surface. The feeders for Devonian hornblende diorite bodies intruding the Frontenac Formation were possibly similar to this postulated dike. Moreover, this anomaly seems to be continuous with the one at Slidedown Mountain for which we must also assume a subsurface magnetic unit of larger magnetic contrast than the exposed hornblende diorite.

More complex aeromagnetic patterns are associated with the preUpper Silurian intrusive and metasedimentary rocks in the southern half of the Attean quadrangle. The complex pattern in the area underlain by the granofels unit is due partly to differences in susceptibility of the granofels, partly to irregular distribution of diorite of higher susceptibility within the unit, and possibly partly to locally reversed remanent magnetism. A very steep magnetic gradient is associated with the diorite in the southwestern part of the quadrangle (pl. 1, profile $A-A^{\prime}$ ). The granofels unit crops out along the crest of a ridge $(\mathrm{SW}-3.5,1.0)$ within this anomalous area, and this granofels is inferred to cap a southward extension of the diorite. The contact on the bedrock geologic map (pl. 1), in an area of thick till, has been drawn to conform to this interpretation. Northward, near the west end of Holeb Pond, another magnetic high is observed over an area of thick till. (See pl.4.) Diorite crops out at the south end and west side of this area and near the north end in a railroad cut. The contacts of two diorite masses are drawn on the geologic map to conform to the magnetic pattern, but it is not clear whether there are actually two intrusive masses of diorite or a single irregular mass.

The magnetic anomalies in the west-central part of the quadrangle (WC-2.0, 3.0) correspond to a small group of diorite outcrops in the center of a large area of thick till. A sample from these outcrops gave the highest measured susceptibility. The magnetic high to the southeast $(\mathrm{WC}-3.5,2.0)$ is over an area concealed by alluvium, but it is just 
south of an area containing abundant irregular masses of diorite within the granofels unit. Diorite is abundant in an area associated with a small anomaly in the central part of the quadrangle $(\mathrm{C}-1.3$, 2.8 ), but no individual mass corresponding to the anomaly was mapped. An attempt was made to locate the rock that causes a sharp anomaly in the southwest (SW-1.0, 1.2), but no outcrop was found in the area.

The magnetic pattern over the Attean Quartz Monzonite is generally uniform and has lower values than that over the granofels unit. Anomalies of medium amplitude are associated with the roof pendant of granofels, and several small anomalies may be caused by inclusions. The cause of the anomaly extending eastward from the northern end of the roof pendant $(\mathrm{C}-2.0,0.2)$ is not clear; good exposures of Attean Quartz Monzonite in this area do not contain inclusions. The small body of Attean Quartz Monzonite on the west border of the quadrangle $(\mathrm{SW}-0.0,3.0)$ was first recognized and located by means of the magnetic low in that area.

The circular magnetic anomaly associated with the Hog Island Granodiorite near Jackman has a magnetic low at its center (pl. 1, profile $\left.D-D^{\prime}\right)$; the anomaly is roughly doughnut shaped. The areal relationships of the anomaly and the surface geology indicate that the high rim is associated with the stock and not with the surrounding rim of contact-metamorphosed rocks. This relation is corroborated by the low susceptibilities of samples of the contact-metamorphosed rocks. However, the lobe on the west side of the anomaly corresponds to the surface pattern of the Upper Silurian conglomerate unit and indicates that the conglometrate has an appreciably high susceptibility. The magnetic low within the main anomaly is centered orer the stock and suggests a zoning in the amount of magnetite within the stock. The low could also be produced by a roof pendant or by abundant inclusions of the cordierite hornfels, which has a low susceptibility (Allingham, 1961). Neither hypothesis could be checked, however, because the center of the stock is not exposed.

Aeromagnetic maps for the adjacent Sandy Bay and Skinner quadrangles (Bromery and Gilbert, 1962) were not available in time to permit geologic field checking. Limited reconnaissance and comparison with the Attean quadrangle, however, suggest explanations for most of the magnetic patterns. The Sandy Bay quadrangle is completely underlain by Devonian rocks and contains no hornblende diorite intrusive bodies large enough to produce an anomaly. Cpper Silurian and Devonian rocks underlie only the northernmost part of the Skinner quadrangle; the contact between these and the older rocks extends west-southwest across the quadrangle. As in the Attean 
quadrangle, the magnetic pattern merely reflects the low regional magnetic gradient. The sharp high-amplitude anomaly on the Canadian border (in the Skinner quadrangle) is related to a large mass of Devonian hornblende diorite. The magnetic pattern overlying the pre-Upper Silurian rocks in the Skinner quadrangle is less irregular than that in the Attean quadrangle. The granofels unit occurs in sevcral areas of sharp high-amplitude anomalies (Skinner quadrangle, eastern edge, southwest corner on Canadian border, and SC-0.2, 4.4), and Attean Quartz Monzonite occurs in several magnetically low areas (Skinner quadrangle, SC-3.9, 1.9; SE-2.7, 4.7; SE-4.1, 3.2). Thus the pattern suggests that the magnetically low areas, which correspond rather well to the topographically low areas, are underlain by Attean Quartz Monzonite and that the magnetically high areas are underlain by granofels. No large bodies of diorite occur within the pre-Upper Silurian rocks in the Skinner quadrangle.

Narrow elongate magnetic lows within otherwise highly magnetic rock are interpreted to be associated with movement or displacement of this rock along zones of shearing or faulting. This interpretation assumes that magnetic minerals in these zones of crushed rock alter to nonmagnetic mineral assemblages and thereby cause narrow nonmagnetic zones (magnetic lows) within magnetic rock (magnetic high). Alinements of nonmagnetic rock give rise to magnetic-low lineaments, which are restricted mainly to magnetic rocks of the granofels unit and Attean Quartz Monzonite. The lineaments trend northeast and northwest; northeast trends are the most conspicuous and abundant. South of Little Big Wood Pond, a magnetic-low lineament parallels the contact between the Seboomook and Frontenac Formations to the northwest and also parallels the dominant northeasttrending fracture pattern throughout this area. This major feature truncates several other lineaments and is thus suggesiive of a large scale late-tectonic element which exerts a fundamental control on the geology. This feature may be a fault which has prevented satisfactory correlation between the conglomerate unit and the Silurian and Devonian rocks north of Little Big Wood Pond. If this is true, the contact between the Seboomook and Frontenac Formation is possibly a similar feature by the analogy of parallelism.

\section{REFERENCES CITED}

Albee, A. L., 1961, Boundary Mountain anticlinorium, west-central Maine and northern New Hampshire: U.S. Geol. Survey Prof. Paper 424-C, p. C51-C54. 1962, Relationships between the mineral association, chemical composition, and physical properties of the chlorite series: Am. Mineralogist, v. 47 , p. $851-870$.

Allingham, J. W., 1961, Aeromagnetic interpretations of zoned intrusives in northern Maine: U.S. Geol. Survey Prof. Paper 424-D, p. D265-D266. 
Bastin, E. S., and Williams, H. S., 1914, Description of the Eastport quadrangle [Maine] : U.S. Geol. Survey Géol. Atlas, Folio 192, 15 p.

Béland, J. R., 1957, St. Magloire and Rosaire-St. Pamphile areas-electoral districts of Dorchester, Bellechase, Montmagny and L'Islet: Quebec Dept. Mines. Geol. Surveys Br. Geol. Rept. 76, 49 p.

Billings, M. P., 1956, The geology of New Hampshire; Pt. 2, Bedrock geology : Concord, New Hampishire State Plan. and Devel. Comm., 203 p.

Boucot, A. J., 1953, The lower Devonian rocks of west-central Maine: Cambridge, Harvard Univ. Ph. D. thesis, $135 \mathrm{p}$.

1954, Age of the Katalidin granite [Maine]: Am. Jour. Sci., v. 252, p. 144-148.

1961, Stratigraphy of the Moose River synclinorium, Maine: U.S. Geol. Survey Bull. 1111-E, p. 153-188.

1962, Appalachian Siluro-Devonian in Coe, Kenneth, ed., Some aspects of the Variscan fold belt: Manchester, England, Manchester Univ. Press, p. 155-163.

Boucot, A. J., Griscom, Andrew, Allingham, J. W., and Dempsey, W. J., 1960, Geologic and aeromagnetic map of northern Maine: U.S. Geol. Survey openfile rept., 2 maps.

Boucot, A. J., Harper, Charles, and Rhea, Keith, 1959, Geology of the Beck Pond area, Township 3-Range 5, Somerset County, Maine: Maine Geol. Survey Spec. Geol. Studies Ser. 1, 33 p.

Bromery, R. W., and Gilbert, F. P., 1962, Aeromagnetic map of the Skinner and parts of the Attean and Sandy Bay quadrangles, Somerset and Franklin Counties, Maine: U.S. Geol. Survey Geophys. Inv. Map GP-310, scale, $1: 62,500$.

Cady, W. M., 1960, Stratigraphic and geotectonic relationships in northern Vermont and southern Quebec: Geol. Soc. America Bull., v. 71, p. 531-576.

Canad'a Geological Survey, 1953, Armstrong-Beauce and Frontenac Counties, Quebec: Canada Geol. Survey Geophys. Paper 120, aeromagnetic map.

1954a, Megantic, Frontenac County, Quebec: Canada Geol. Survey Geophys. Paper 152, aeromagnetic map.

- 1954b, Woburn, Frontenac County, Quebec: Canada Geol. Survey Geophys. Paper 168, aeromagnetic map.

- 1954c, La Patrie, Compton and Frontenac Counties, Quebec: Canada Geol. Survey Geophys. Paper 172, aeromagnetic map.

Canney, F. C., and Post, E. V., 1964, Suggested exploration target in west-central Maine: U.S. Geol. Survey Prof. Paper 501-D, p. D61-D64.

Clarke, J. M., 1907, Some new Devonic fossils: New York State Mus. Bull. 107, Geol, 12, p. 153-291.

1908-1909, Early Devonic history of New York and eastern North America : New York State Mus. Mem. 9, pt. 1, 366 p.; pt. 2, 250 p.

de Sitter, L. U., 1956, Structural geology: New York, McGraw-Hill Book Co., $552 \mathrm{p}$.

Dresser, J. A., and Denis, T. C., 1944, Descriptive geology, v. 2 of Geology of Quebec: Quebec Dept. Mines, Geol. Rept. 20, 544 p.

Ells, R. W., 1887, Report on the geology of a portion of the Eastern Townships [Quebec], relating more especially to the counties of Compton, Stanstead, Beauce, Richmond, and Wolfe: Canada Geol. Nat. History Survey 2d Ann. Rept., 1886, pt. J., 70 p., map.

Faessler, Carl, 1939, Risborough-Marlow area, Frontenac County [Quebec] : Quebec Bur. Mines, Geol. Div., Geol. Rept. 3, 18 p. 
Fairbairn, H. W., Faure, Gunther, Pinson, W. H., Jr., Hurley, P. M., and Powell, J. L., 1963, Initial ratio of strontium 87 to strontium 86 , whole-rock age and discordant biotite in the Monteregian igneous province, Quebec: Jour. Geophys. Resea rch, v. 68, p. 6515-6522.

Fairbairn, H. W., Hurley, P. M., Pinson, W. H., Jr., and Cormier, R. F., 1960, Age of the granitic rocks of Nova Scotia: Geol. Soc. America Bull., v. 71, p. $399-414$.

Faul, Henry, Stern, T. W., Thomas, H. H., and Elmore, P. L. D., 1963, Ages of intrusion and metamorphism in the northern Appalachians: Am. Jour. Sci., v. 261, p. 1-19.

Fenneman, N. M., 1938, Physiography of eastern United States: New York, McGraw-Hill Book Co., 714 p.

Flint, R. F., 1951, Highland centers of former glacial outflow in northeastern North America: Geol. Soc. America Bull., v. 62, p. 21-38.

— 1953, Probable Wisconsin substages and late Wisconsin events in northeastern United States and southeastern Canada: Geol. Soc. America Bull., v. 64, p. 897-920.

Green, J. C., 1962, Stratigraphy and correlation of the Boundary Mountain anticlinorium, northernmost New Hampshire [abs.]: Geol. Soc. America, Ann. Mtg., Houston, Tex., 1962, Program, p. 62A.

Hatch, N. L., Jr., 1963, Geology of the Dixville quadrangle, New Hampshire: New Hampshire Dept. Resources and Econ. Devel. Bull. 1., 81 p.

Hitchcock, C. H., 1878, Atlas accompanying report on the geology of New Hampshire : New York.

Hitcheock, C. H., and Huntington, J. H., 1874, Geology of the northwestern part of Maine: Am. Assoc. Adv. Sci. Proc. 22, p. 205-214.

Holmes, Ezekiel, and Hitchcock, C. H., 1861, Preliminary report upon the natural history and geology of the State of Maine, 1861: Maine Board Agriculture, 6th Ann. Rept., p. 91-458.

1862, Second annual report upon the natural history and geology of the State of Maine, 1862 : Maine Board Agriculture, 7th Ann. Rept., 447 p.

Hurley, P. M., 1960, Summary of K-Ar ages from the Monteregian Hills : Massachusetts Inst. Technology, Dept. Geology and Geophysics 8th Ann. Prog. Rept. to U.S. Atomic Energy Comm., p. 283.

Hurley, P. M., Boucot, A. J., Albee, A. L., Faul, Henry, Pinson, W. H., Jr., and Fairbairn, H. W., 1959, Minimum age of the Lower Devonian slate near Jackman, Maine: Geol. Soc. America Bull., v. 70, p. 947-950.

Hurley, P. M., and others, 1958, Variations in isotopic abundances of strontium, calcium, and argon and related topics: U.S. Atomic Energy Comm. [Pub.] NYO-3939, Contract AT (30-1)-1381, 196 p.

Hurley, P. M., and Thompson, J. B., Jr., 1950, Airborne magnetometer and geological reconnaissance in northwestern Maine: Geol. Soc. America Bull., v. 61, p. 835-842.

Jackson, C. T., 1837, First report on the geology of the State of Maine : Augusta, Maine, Maine Geol. Survey, 128 p.

Johns, W. D., Grim, R. E., and Bradley, W. F., 1954, Quantitative estimations of clay minerals by diffraction methods: Jour. Sed. Petrology, v. 24, p. 242251.

Keith, Arthur, 1933, Preliminary geologic map of Maine: Maine Geol. Survey, scale 1: 1,000,000 (issued as supplement to Maine Tech. Expt. Sta. Bull. 30, v. 2, 1935). 
Logan, W. E., 1849 [On the geology of the country on the south side of the St. Lawrence from Montreal and Iake Champlain to the Chaudiere River, Quebec] : Canada Geol. Surves, Rept. Prog. 1847-48, p. 5-92.

Lord, C. S., 1938, Geologic map. Megantic sheet (west half), Frontenac County, Quebec: Canada Geol. Survey Map 379A, sca'e 1:63.360.

Lowden, J. A., 1960, Age determinations by the Geological Survey of Canada: Canada Geol. Survey Paper 60-17, $51 \mathrm{p}$.

—_ 1961, Age determinations by the Geological Survey of Canada (Report 2) : Canada Geol. Survey Paper 61-17, 127 p.

Lyons, J. B., Jaffe, H. W., Gottfried, David, and Waring, C. L., 1957, Lead-alpha ages of some New Hampshire granites: Am. Jour. Sci., v. 255, p. 527-546.

MacKay, B. R., 1921, Beauceville map-area, Quebec: Canada Geol. Survey, Mem. $127,90 \mathrm{p}$.

Marleau, R. A., 1957, Preliminary report on Woburn area, e'ectoral district of Frontenac: Quebec Dept. Mines, Geol. Surreys Br. Prelim. Rept. 336, p 6.

- 1958a, Preliminary report on East Megantic and Armstrong areas, electora! districts of Frontenac and Beauce: Quebec Dept. Mines, Geol. Surveys Br. Prelim. Rept. 362. 7 p.

- 1958b, Geology of the Woburn, East Megantic and Armstrong areas, Frontenac and Beauce Counties, Quebec: Quebec Univ. Laval, Ph. D. thesis, $184 \mathrm{p}$.

1959, Age re'ations in the Lake Megantic Range, southern Quebec: Geol. Assoc. Canada Proc.. v. 11, p. 129-139.

McGerrigle, H. W., 1935, Mount Megantic area, southeastern Quebec, and its placer-go!d deposits: Quebec Bur. Mines Ann. Rept. 1934, pt. D, p. 63-104.

Perkins, E. H., 1925. The Moose River Sandstone and its associated formations: Am. Jour. Sci., v. 10, p. 368-375.

1934, The official map of Maine; G'acial deposits, State of Maine: Maine Geol. Survey, sca'e 1:400.000 (issued as supplement to Maine Tech. Exper. Sta. Bull. 30, v. 2, 1935).

Rose, H. J., Jr., and Stern. T. W.. 1960. Spectrochemical determination of lead in zircon for lead-a!pha age measurements : Am. Mineralogist, v. 45, p. 12431256.

Shapiro, Leonard, and Brannock, W. W., 1956, Rapid analysis of silicate rocks : U.S. Geol. Survey Bull, 1036-C, p. C19-C56.

Shaw, D. M., 1956, Major elements and general geochemistry, Pt. 3 of Geochemistry of pe'itic rocks: Geol. Soc. America Bu'l., v. 67, p. 919-934.

Smith, D. G. W., Baadsgaard, Halfdan. Fo'insbee, R. E., and Lipson, J. I.. 1961, K/Ar age of Lower Devonian bentonites of Gaspé. Quebec, Canada: Geol. Soc. America Bull.. v. 72, p. 171-173.

Stern. T. W., and Rose, H. J.. Jr., 1961. New results from lead-alpha age measurements: Am. Mineralogist. v. 46, p. 606-612.

White, W. S., 1949, Cleavage in east-central Vermont: Am. Geophys. Union Trans., v. 30, p. 587-594.

Wil'iams, H. S., and Breger, C. L.. 1916. The fauna of the Chapman Sandstone of Maine, including descriptions of some related species from the Moose River Sandstone: U.S. Geol. Survey Prof. Paper 89, $347 \mathrm{p}$.

Wasserburg, G. J., Albee. A. I., and Lanphere, M. A.. 1964, Migration of radiogenic strontium during metamorphism: Jour. Geophys. Research, r. 69, no. 20, p. 4395-4401. 



\section{INDEX}

[Italic page numbers indicate major references]

A

Acadian orogeny . . ............... 11, 12,60,84,85

Accessibility to area.

Acknowledgments

Aeromagnetic map, geologic interpretation...

Albee Formation.

Albite twinning.

Alluvial deposits

Alteration, dikes, Early Devonian or younger age.

hornblende diorite.

quartz porphyry.

Ammonoosue Volcanics

Ancient shore features.

Aplitic Quartz Monzonite, cataclastic texture. pre-Upper Silurian rocks

Artificial fill.

Attean Mountain

Attean Pond $1,68,91,96$

Attean Quartz Monzonite
$19,28,29,33,37,42,63,66,67,83,85,86$ $90,95,97,99$

cataclastic zone

$28,37,72$

mineral composition

plagioclase

pre-Upper Silurian rocks

secondary minerals

$\mathrm{X}$-ray diffraction patterns

\section{B}

Balazs, M., analyst

Barrett Pond

Becraft-Oriskany time

Bedding schistosity

Bedrock geology

Benjamin Pond

Bibliography

Bog Pond.

Boulder fields.

Boulder Pond

Bouldery till

Boundary Mountain anticlinorium ...... 7,66,67,82

Burnt Jacket Mountain

Cambrian age

Cambro-Silurian age

Camera Hill

Carlsbad, twinning

Cataclasis, Attean Quartz Monzonite. quartz porphyry

Cataclastic deformation 13,19

Fossils:

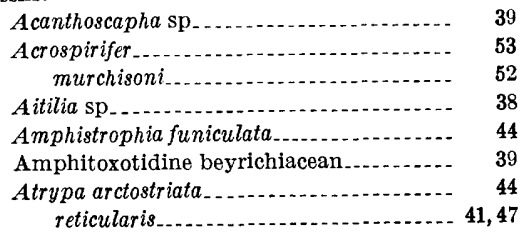

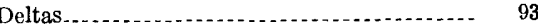

Diorite, composition and texture............. 19 contact relations with granofels unit...... $\quad 20$ pre-Upper silurian rocks................. 18

Dixville Notch rocks........................ 9

Early Devonian age........................ 10

Early Devonian or younger age.............. 58

F

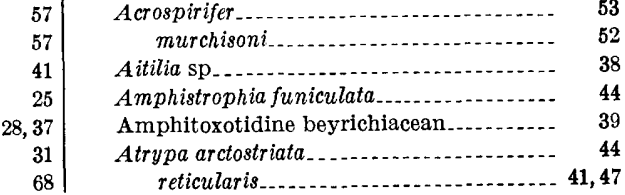

Page

Cataclastic schistosity, Attean Quartz monzonite

Cataclastic zone..................... 28, 72,83

Attean Quartz Monzonite............... 37 quartz porphyry .

Catheart Mountains......................... 28

Chlorite-grade metamorphism.............. 84,85

Cleavage folding ......................... 82

Coburn Pond . . . . ............................ 92

Compton Formation........................ 58

Concentric folding........................... 82

Conglomerate unit, composition............. 43

Upper Silurian rocks. ................. 42

Conglomeratic sandstone unit, Lower Devonian rocks......................... 45

Upper Silurian rocks. ..................... 45

Connecticut Valley-Gaspé synclinorium _..... $\quad 7,66$

Construction materials........................ 93

Contact-metamorphic aureole, Hog Island Granodiorite. ..................... 86

Contact-metamorphic rocks, associated with t ie Hog Island Granodiorite ...... 43,64

Early Devonian or younger age.......... 64

Cretaceous age .

Crocker Pond . . . . . . . . . . . . . . . . . . . . . . 48, 96

Culture of area........................... 2

D $\mathbf{E}$

Décollement................................. 83 
Fossils-Continued

Auloporoid coral

Brachlopods.

Bryozoan

Camarotoechia sp

Camarotoechild

Cephalopod.

Cladopora sp

Clathrospira.

Coelospira concava saffordi.

Corals.

Cornulites sp.

Crinoid columnals

Dizygopleura costata

Dolerorthid sp.

Dolerorthis hami

Eccentricosta jerseyensis $\quad 37,39,40,44,45,47$ sp

Eukloedenella $\mathrm{sp}$

Euomphalopterus gasconensis

Favosites sp.

Gastropods

Gypidula sp. 2

Halysites sp

Horn corals

Howellella sp

Isorthis.

$\mathrm{sp}$ $38,39,40,41,44,47,52$

Page

40

52

39,40

38

38

Kloedenella $\mathrm{sp}$........................ 38

Kloedenia sp. . . ........................ 39,41

Leiocyamus $\mathrm{sp} \ldots \ldots \ldots$

Leperditia . .............. 37,41

(Leperditia) $\mathrm{sp}_{\ldots} \ldots \ldots \ldots . . . . . . . . . . . .39$

sp.

40,41

Leptocoelia

fiabellites.

sp.

Leptostrophia $\mathrm{sp}$

Limbinaria muricata

$\mathrm{sp}$

Lissatrypa sp.

Loxonema sp.

Mirochilina sp.

Orthostrophia brownsportensis

Ostracodes

Pelecypod

Phycolites.

Pintopsis tricornis

sp.

Platyceras (Visitator) sp.

Platyceratids.

Platyostoma sp.

Proetus (Proetus) sp

Protathyris.

sp

Retisacculus

Rhynchonellid

Sphaerirhynchia sp. 1

Stromatoporoids.

Syringopora sp.

Syringoporold coral
Fossils-Continued

Page

Tentaculites $\mathrm{sp}$

Trilobite............................... 39, 40

Tryplasma sp.......................... 40

Velibeyrichia sp......................... 41

Worm tube........................... 39

Zygobeyrichia sp....................... $\quad 39$

Fox Limestone . . . . . . . . . . . 34

Foxs Camp....................... 4, 34, 45, 73,77

Frontenac Formation.... $7-11,48,58,59,73,78,95,99$

composition................ 55

Lower Devonian rocks................. 53

texture................................... 55

Frontenac synclinorium $\ldots \ldots \ldots \ldots \ldots \ldots \ldots . . .67,66,82$

\section{G}

Gander Pond......... 35

Gaspé................. 64, 89

Gaspé synclinorlum. See Connectlcut ValleyGaspé synclinorium.

Gedinnian unit........................... 36

Geochemical anomaly .................... 68

Geologic plotting. ......................... 5

Geologic setting...........................

Geology, correlation with topography ...... 13

Geomorphology ......................... 12

Glacial deposits. 5

Glacial quarrying $\ldots$

Glacial till............. 14

Granofels unit.................... 29, 99

composition ........................... 15

fibrous sillimanite.................... 16

pre-Upper Silurian rocks. ................ 14

texture

Green, John, cited

Green Mountain-Sutton Mountain anticlinorium 7

Green Mountain-Sutton Range............. 57

\section{H I J}

Hardwood Mountain Formation ........... 34,41

Harwood, D.S., cited...................... 83

Highlandcroft Plutonic Series... .......... 9, 33,89

Hobbstown Formation . .................... 41,44

Hog Island................. 61,65

Hog Island Granodiorite....... 4, 42, 59, 61, 86, 95, 97

Early Devonian or younger rocks.

mineral composition..................... 62

texture.................................... 62

Holeb. .................... 92

Holeb Falls. . . . . . .

Holeb Pond........... 68, 96

Hornblende diorite $\ldots$

composition. ........................ 60

Early Devonian or younger rocks ........ $\quad 59$

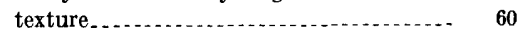

Hornfels....................... 64

Horseshoe Pond. . . .

39 Huronian age.......................... 57

38 Hyman, H. H., analyst................... 49

Ice, erosion ............................... 95

Ice-channel deposits ....................... 14, 92

38 Jackman _.......... . . . . . . . . . . . . . . 61,91

$44 \mathrm{Jim}$ Pond ............................. 32 
Kennebec drainage.

Kennebec Formation.

Kineo Volcanic Member, Tomhegan Formation ..............................

Knickpoint, bedrock boulder-pile

Knickpoints.

87

13

\section{L}

Late Silurian-Early Devonian time

Limestone and slate unit, Upper Silurian rocks.

Little Big Wood Pond

Little Turner Pond. $23,72,91,96$

Littleton Formation

Llandovery age

Location of area

Logging.

Long Pond ................ 29, 92, 96

Low-angle strike faults

Lower Devonian rocks conglomeratic sandstone unit.

Frontenac Formation structural features

Ludlow unit, Upper Silurian rocks

\section{M}

McKenney Pond.

Mafic dikes, pre-Upper Silurian rocks

Magnetic susceptibilities.

Metamorphism

Moose River 91,100

Moose River synclinorium ....... . 3, 7, 32, 57, 61, 66, 85 Devonian rocks.

Moose River village

Mount Megantic.

Muck

Mud Pond

Muscovite, quartz porphyry

\section{$\mathrm{No}$}

Natural dam.

Naylor, R. S., cited

New Scotland age

Nictauw

No. 5 Bog

No. 5 Mountain

No. 6 Mountain .

Ordovician age

Oriskany time. See Becraft-Oriskany time.

Outwash sand and gravel.

\section{$\mathrm{P}$}

Paleogeography

Parlin Pond.

Parmachenee Lake

Peat

Pittston Farm

Plagioclase, alteration products composition. structural state.

Portage trails.
Post-Early Devonian metamorphism _. $11,21,89$

Potassium feldspar, twinning .............. 25

Pre-Upper Silurian rocks. ................... 7,14

age, correlation ......................... 32

Attean Quartz Monzonite ................ 21

diorite................................. 18

granofels unit........................... 86

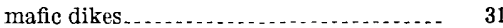

metamorphism ...................... 84

quartz porphyry . ....................... 29

schistose shear zones. .................. 68

structural features......................... 67

Q

Quartz-feldspar porphyry dikes............... 61

Quartz porphyry, composition and texture... $\quad 30$ pre-Upper Silurian rocks................ 29

Quaternary geology ........................ 90 preglacial topography ................ 95 surficial deposits ...................... 90

$\mathrm{R}$

Radiometric age determinations.......... $8 i$

Reference system.......................... 6

Remanent magnetism...................... 98

Reversed remanent magnetism............. 100

Roads ...................... 3

$\mathrm{S}$

St. Lawrence drainage.................... 13 Sally Mountain................. 13, 29, 42, 66, 68, 91 Sandy Bay quadrangle ................... 101 Sandy Stream........................... 81, 92 Sandy St"eam Mountain . . ............... 13, 54,59 Schistose shear zones, pre-Upper Silurian rocks $\ldots$

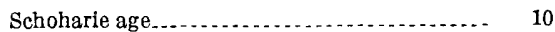

Seboomook Dam ...................... 47

Seboomook Formation . ................... 5, $11,35,42,45,47,61,63,64,73,81,86,95,99$ composition.......................... 49 Lower Devonian rocks . . .................. 47 texture ............................... 49

X-ray diffraction. ......................... 49

Seboomook Lake......................... 56

3 Seboomook Slate ........................ 47
12,29
Shear folding . . . .

Shearing

Sillimanite-grade metamorphism ........... 84

Skinner quadrangle . . . . . . . . . . . . . . . . . ... 101

Slidedown Mountain _ . ............. 13, 54, 59, 73, 99

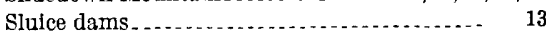

Spencer Rips_................................ 93

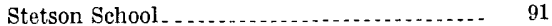

Structural geology........................... 66

Structural synthesis ...................... 82

Sugar Berth Pond. . . . . . . . . .

Surficial deposits, quaternary geology ....... 90

Sutton Mountain anticlinorium. See Green Mountain-Sutton Mountain anticlinorium. 


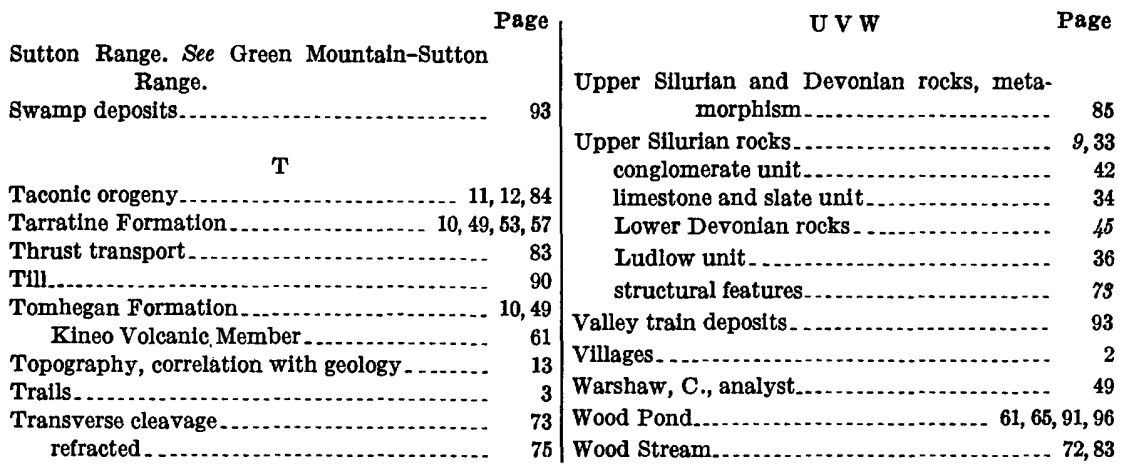





